\title{
Többimpulzusos lézer indukált plazmák jellemzése és atomspektroszkópiai alkalmazása
}

Doktori (Ph.D.) értekezés

\author{
Jedlinszki Nikoletta \\ okleveles vegyész
}

Témavezető: Dr. Galbács Gábor

egyetemi docens

Kémia Doktori Iskola

Szegedi Tudományegyetem

Természettudományi és Informatikai Kar

Szervetlen és Analitikai Kémiai Tanszék

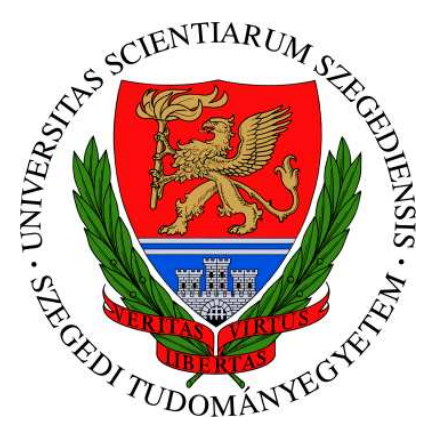




\section{Tartalomjegyzék}

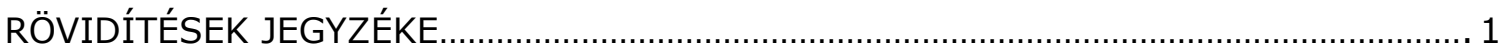

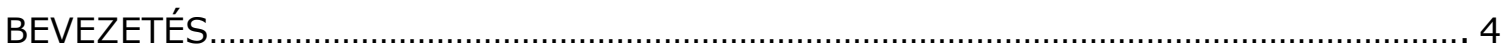



1.1. A LIBS müködési elve és rövid története....................................................5

1.2. A LIBS készülékek részei.......................................................................... 8

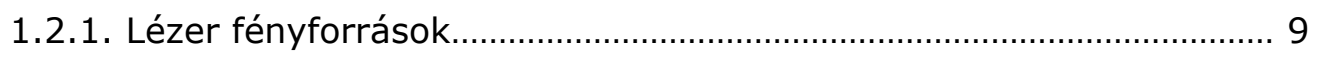

1.2.2. A fókuszáló és fénygyűjtő optikai rendszer......................................... 10

1.2.3. A spektrométer és a detektor............................................................ 12

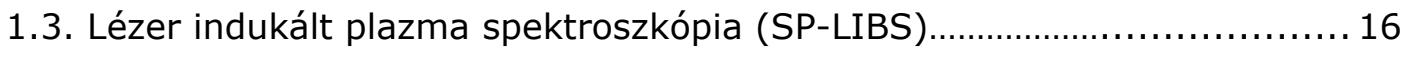

1.3.1. Az ablációt befolyásoló paraméterek.................................................. 19

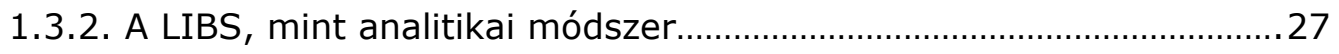

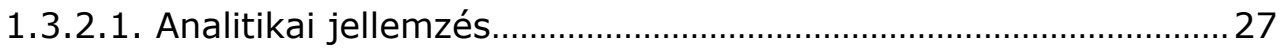

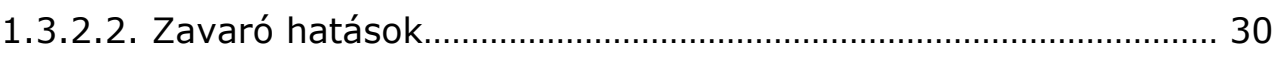

1.3.2.3. Az analitikai teljesítőképesség javítása normalizációs és speciális kalibrációs módszerek alkalmazásával..................... 31

1.4. Kétimpulzusos lézer indukált plazma spektroszkópia (DP-LIBS)..................37

1.5. Többimpulzusos lézer indukált plazma spektroszkópia (MP-LIBS)..............44

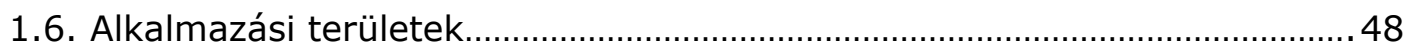

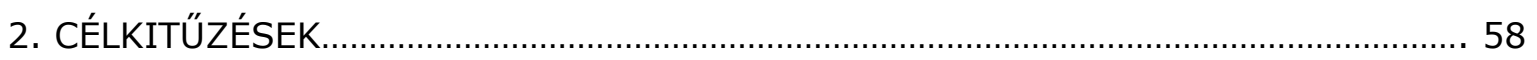

3. MÜSZEREK, FELHASZNÁLT ANYAGOK ÉS ESZKÖZÖK...............................................59

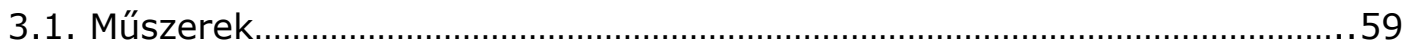

3.2. Felhasznált anyagok és eszközök................................................................ 63



4.1. Az ablációs folyamatok és a plazmák térbeli, időbeli jellemzőinek vizsgálata 
4.1.1. Az ablációs jellemzők tanulmányozása............................................ 65

4.1.2. A plazma térbeli és időbeli fejlődése................................................... 71

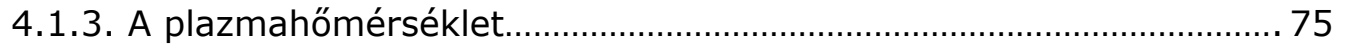

4.1.4. Az emissziós jel késletetési időtől való függése................................... 77

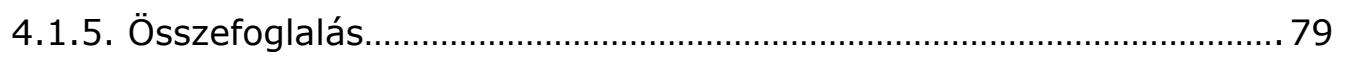

4.2. Az analitikai teljesítőképesség jellemzése.................................................... 80

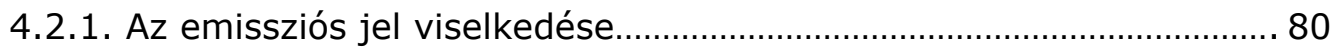

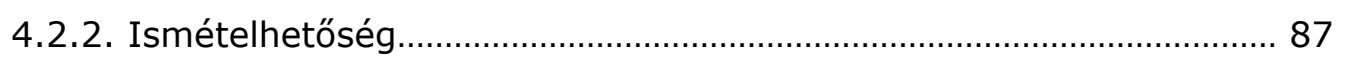

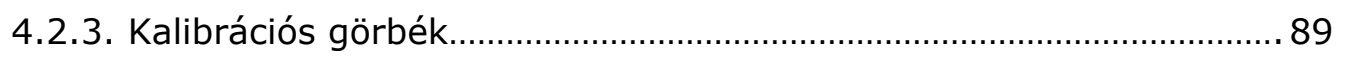

4.2.4. Kimutatási határok ................................................................................ 91

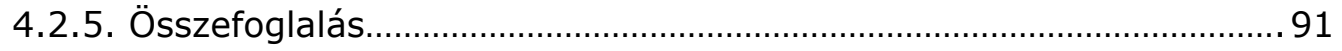

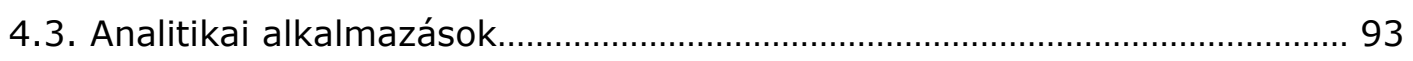

4.3.1. Aranyötvözetek kvantitatív elemzése.................................................... 93

4.3.2. Forrasztófémek kvantitatív elemzése..............................................100

4.3.3. Jelnormalizációs eljárás alkalmazása...............................................103

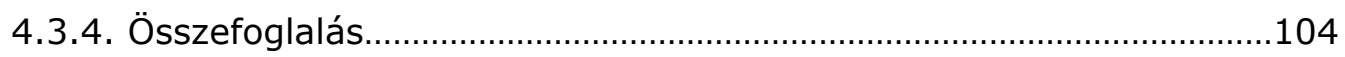



6. SUMMARY

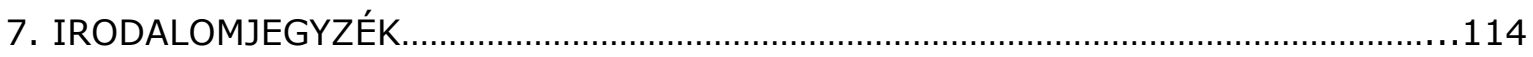



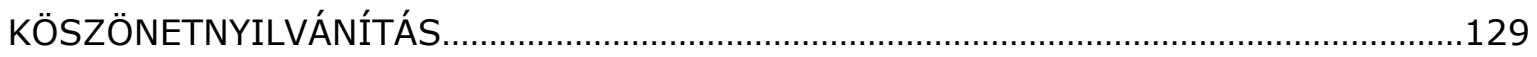




\section{Rövidítések jegyzéke}

AAS

AES

APXS

CCD

CF-LIBS

DP-LIBS

FAAS

GD-OES

GF-AAS

GLCM

HPLC

iCCD

ICP-AES

ICP-MS

LA-ICP-MS
Atomabszorpciós spektroszkópia (Atomic Absorption Spectroscopy)

Atomemissziós spektroszkópia (Atomic Emission Spectroscopy)

Alfa részecske röntgen spektrometria (Alpha Particle X-ray

Spectrometer)

Töltés-csatolt eszköz (Charge-Coupled Device)

Kalibrációmentes lézer indukált plazma spektroszkópia (Calibration-Free Laser Induced Breakdown Spectroscopy)

Kétimpulzusos lézer indukált plazma spektroszkópia (Double-Pulse Laser Induced Breakdown Spectroscopy)

Lángatomabszorpciós spektroszkópia (Flame Atomic Absorption Spectroscopy)

Glimmkisülési optikai emissziós spektroszkópia (Glow Discharge Plasma Optical Emission Spectrometry)

Grafitkemencés atomabszorpciós spektroszkópia (Graphite Furnace Atomic Absorption Spectrometry)

Általánosított lineáris korrelációs kalibráció (Generalized Linear Correlation Method)

Nagyhatékonyságú folyadékkromatográfia (High-Performance Liquid Chromatography)

Intenzifikált töltés-csatolt eszköz (Intensified Charge-Coupled Device)

Induktív csatolású plazma atomemissziós spektroszkópia (Inductively

Coupled Plasma Atomic Emission Spectroscopy)

Induktív csatolású plazma tömegspektrometria (Inductively Coupled

Plasma Mass Spectrometry)

Lézerablációs induktív csatolású plazma tömegspektrometria (Laser

Ablation Inductively Coupled Plasma Mass Spectrometry) 
LIB Lézer indukált letörés (Laser Induced Breakdown)

LIBS Lézer indukált letörési spektroszkópia (Laser Induced Breakdown Spectroscopy)

LIP Lézer indukált plazma (Laser Induced Plasma)

LIPS Lézer indukált plazma spektroszkópia (Laser Induced Plasma Spectroscopy)

LOD Kimutatási határ (Limit of Detection)

LOQ Meghatározási határ (Limit of Quantitation)

MCP Mikrocsatornás lemez (Microchannel Plate)

MP-LIBS Többimpulzusos lézer indukált plazma spektroszkópia (Multi-Pulse Laser Induced Breakdown Spectroscopy)

MS

Tömegspektrometria (Mass Spectrometry)

NAA Neutronaktivációs analízis (Neutron Activation Analysis)

Nd:GGG Neodímiummal dópolt gránátszerü gadolínium-gallium-oxid kristály (Neodymium Doped Gadolinium Gallium Garnet)

Nd:YAG Neodímiummal dópolt gránátszerü ittrium-alumínium-oxid kristály (Neodymium Doped Yttrium Aluminium Garnet)

PIXE Protonindukált röntgenemissziós analízis (Proton Induced $X$-ray Emission)

PMT Fotoelektron-sokszorozó (Photomultiplier Tube)

SD-OES Szikragerjesztésű optikai emissziós spektroszkópia (Spark Discharge Plasma Optical Emission Spectrometry)

SEM Pásztázó elektronmikroszkópia (Scanning Electron Microscope)

SEM-EDS Energiadiszperzív röntgen spektrométerrel felszerelt pásztázó elektronmikroszkóp (Scanning Electron Microscope Equipped with an Energy Dispersive $X$-ray Spectrometer)

SP-LIBS Egyimpulzusos lézer indukált plazma spektroszkópia (Single-Pulse Laser Induced Breakdown Spectroscopy)

STEM Pásztázó transzmissziós elektronmikroszkóp (Scanning Transmission Electron Microscopy) 
XRD Röntgendiffrakciós analízis ( $X$-ray Diffraction)

$\mathrm{XRF}$

Röntgen-fluoreszcencia spektrometria (X-ray Fluorescence)

XRMA Röntgensugár mikroanalízis ( $X$-Ray Micro-Analysis) 


\section{Bevezetés}

A lézer fényforrások számos, az atomspektrometriai módszerek számára vonzó tulajdonsággal rendelkeznek. Ezek közül a legfontosabb a nagyfokú irányítottság, a nagyon keskeny sávszélesség és nagy fényintenzitás. Az impulzusüzemben müködő lézerekkel óriási teljesítménysürüség is elérhető, amelyekkel szilárd minták pontszerüen lebonthatók, elpárologtathatók. Mindezeken túl egyes lézertípusok még hangolhatók is; ezek alkalmazási lehetőségei még sokoldalúbbak az atomspektroszkópiában. A lézer fényforrások mindezen tulajdonságainak kiaknázásával az elmúlt évtizedek alatt az atomspektrometriában számos új mérési módszer jött létre, illetve a már ismert módszerek analitikai teljesítőképessége is jelentősen megnőtt.

$A z$ egyik ilyen újszerű lézeres atomspektrometriai módszer a lézer indukált plazma spektroszkópia (LIBS/LIPS), amely a minta felületén keltett mikroplazma emissziós megfigyelésén alapul. Ez a módszer lényegi mintaelőkészítés nélkül tetszőleges, kondenzált vagy gázfázisú minta elemösszetételének nyomanalitikai vizsgálatát teszi lehetővé akár távolról vagy terepen is, szükség esetén térbeli vagy mélységi felbontással. Ezen előnyös tulajdonságoknak és az optoelektronikai eszközök rohamos fejlődésének köszönhetően a LIBS módszer analitikai alkalmazásainak száma az elmúlt évtizedben rohamosan bővült; mára az ürkutatástól a gyógyszeriparig, a katonai/antiterrorista célú mérésektől a mütárgyak és környezeti minták vizsgálatáig igen sok mindent magában foglal.

Ezzel párhuzamosan intenzív, a lézer indukált plazmában lejátszódó folyamatokkal és a LIBS módszer analitikai teljesítőképességének fejlesztésével kapcsolatos fizikai és analitikai spektroszkópiai alapkutatás folyik a plazma spektroszkópiai laboratóriumokban. Lézer- és plazma spektroszkópiai kutatócsoportunk 2000 óta foglalkozik a tanszéken Galbács Gábor vezetésével a lézer indukált plazmák tanulmányozásával, a LIBS módszer fejlesztésével és analitikai alkalmazásaival. A kutatócsoport tagjaként ezekbe a kutatásokba kapcsolódtam be 2006-ban. Kutatásaim közvetlen célja a kettő vagy több, kolineáris lézerimpulzussal keltett plazmák jellemzőinek és analitikai teljesítőképességének vizsgálata volt. 


\section{Irodalmi áttekintés}

\subsection{A LIBS müködési elve és rövid története}

A lézer indukált plazma spektroszkópia (LIBS/LIPS) az emissziós atomspektroszkópiai módszerek csoportjába tartozó méréstechnika. A módszer mérési elve a következőképpen fogalmazható meg: ha egy nagy teljesítményű lézer fénysugarát a mintára (gáz-vagy folyadékminta esetén annak belsejébe) fókuszáljuk, a fókuszfoltban kialakuló nagy teljesítménysürüség $\left(10^{6}-10^{12} \mathrm{~W} / \mathrm{cm}^{2}\right)$ következtében a minta lebomlik. A mintából kiszakadt atomokból, ionokból, fragmentumokból néhány tíz us élettartamú mikroplazma jön létre, mely rendkívül magas, több tízezer Kelvin hőmérsékletű. A mikroplazmában a mintából származó atomok, molekulák gerjesztődnek, illetve ionizálódnak. A módszer alkalmas mind kvalitatív, mind kvantitatív analitikai meghatározásokra az anyagok igen széles skáláján, úgymint fémötvözetek, folyadékok, műanyagok, aeroszolok, kerámiák, stb., eltérő körülmények között.

A LIBS módszer fejlődésének részletes leírása számos cikkben [1-5] és szakkönyvben (pl. [6]) megtalálható, ezért ebben a fejezetben csak a jelentősebb mérföldkövekről teszek említést. A LIBS készülékek alapvető és kitüntetett része a lézer, ezért tágabb értelemben a módszer fejlődésének kezdete 1917-re tehető, amikor Einstein megfogalmazta a gerjesztett fénykibocsátás (stimulált emisszió) elméletét [7]. Ez a felfedezés tette lehetővé később a lézer fényforrások létrejöttét. Az első lézert (laser $=$ Light Amplification by Stimulated Emission of Radiation) Maiman fejlesztette ki 1960-ban. A prototípus anyaga, amelyben a lézereffektus lejátszódott, rubin kristály volt, gerjesztésként pedig egy villanólámpa fénye szolgált [8]. Két évvel később Brech és Cross már bemutatták a lézerek spektroszkópiai célokra való alkalmazhatóságát is, de a lézert csak az abláció létrehozására használták [9]. A lézerek első analitikai alkalmazásáról szóló tanulmányt Debras-Guédon és Liodec publikálta 1963-ban, akik felületi spektrokémiai analízist végeztek [10]. 1964-ben Runge és társai kalibrációs görbéket határoztak meg vas mátrixban nikkelre és krómra, $5.3 \%$-os és $3.8 \%$-os precizitással, valamint analizáltak fémolvadékokat is [11]. Ugyanebben az évben bevezették a forgó tükrös detektálást ("streak" kamera), amely lehetővé tette az időbeli felbontást. Ennek köszönhetően a plazma élettartamának korai szakaszában jelenlévő folytonos emisszió már elkülöníthető volt a későbbi, atomoktól és ionoktól származó jeltől. 
Az első, kereskedelmi lézeres analitikai müszereket 1964 és 1967 között építették meg: Carl Zeiss Jena Corp. (Germany), Jarrell-Ash Corp. (USA) és JEOL Ltd. (Japan). Ezekben a berendezésekben maga a lézer is létre tudta hozni a plazmát, mégis a leggyakrabban csak az abláció létrehozására használták, és az atomok gerjesztését konvencionálisan, szikrakisüléssel oldották meg. A müszerek pontossága és precizitása nem kelhetett versenyre a hagyományos szikragerjesztésű spektroszkópiai módszerekkel, azonban kezelni tudott elektromosan szigetelő mintákat is. Néhány ilyen berendezés egészen az 1990-es évekig használatban maradt. Ezen korai készülékek és a hozzájuk kapcsolódó technikák részletes leírása megtalálható egy 1989-ben megjelent, Moenke-Blankenburg által írt könyvben [12].

Az 1970-es években számos, LIBS témájú alapkutatásról és alkalmazásról beszámoló publikáció jelent meg, nagy részük oroszul. Szintén ebben az időszakban kezdődött el a mátrixhatás vizsgálata, amely azt mutatta, hogy a fizikai paraméterek (pl. szemcseméret) és a minta kémiai összetétele nagymértékben befolyásolják a LIBS jelintenzitást és precizitást. Marich és társai ezüstöt és magnéziumot vizsgáltak szarvasmarha és emberi fehérjében és azt tapasztalták, hogy a fizikai tulajdonságok hatása sokkal jelentősebb, mint a kémiai tulajdonságoké [13]. Mások, például Scott és Strasheim úgy gondolták, hogy a jelcsökkenést többféle hatás okozza, amelyek a mátrix komponenseihez köthetők [14]. A mai napig elfogadott, hogy a jelintenzitást és az ismételhetőséget nagymértékben befolyásolják a minta fizikai és kémiai tulajdonságai.

Az 1980-as években egyre inkább nőtt az érdeklődés a kvantitatív LIBS mérések iránt. Radziemski és társai több tanulmányt készítettek ezen a területen [15-17]. Berillium, nátrium, foszfor, arzén, higany, klór és fluor mennyiségi meghatározását végezték el és a nátrium esetében négy nagyságrenden keresztül lineáris kalibrációs görbét vettek fel. Az évtized végén megjelent az első, Radziemski és Cremers által szerkesztett LIBS vonatkozású könyv, amely összefoglalta az aktuális alkalmazásokat és eredményeket, valamint tartalmazott egy részletes fejezetet a "breakdown" és a „post-breakdown” jelenségének legfrissebb értelmezéséről is [18].

Az 1990-es években az eszközök fejlődésének köszönhetően (pl. a gyors, időfelbontásos detektálás lehetősége) a LIBS kutatások is igen gyors fejlődésnek indultak. Több hasznos áttekintő tanulmány is megjelent ebben az időszakban [3, 4, 19]. A LIBS távoli mérésekre való alkalmazása - amely már a 80-as években elkezdődött [20] - is rohamosan terjedt ezekben az években [21-23], valamint egyre inkább nőtt az érdeklődés a módszer kvantitatív analitikai felhasználására is. 1999-ben Tognoni és társai kifejlesztették a "calibration-free LIBS"-et (CF-LIBS), amely módszer kvantitatív analitikai mérések kivitelezését teszi lehetővé standard anyagok vagy kalibrációs görbék nélkül [24]. 
Az új évezred kezdetétől kezdődően új nemzetközi konferenciák sora nyújtott kiváló lehetőséget a kutatók számára, hogy bemutassák a LIBS alkalmazások egyre szélesedő spektrumát (pl. EMSLIBS - Euro-Mediterranean Symposium on Laser Induced Breakdown Spectroscopy; NASLIBS - North American Symposium on Laser Induced Breakdown Spectroscopy; stb). A legújabb kutatási területek közé tartozik pl. a spektrumok VUV tartományának a felfedezése, biológiai vizsgálatok, katonai és antiterrorista alkalmazások, mintafelszínek feltérképezése. Amint azt az 1-1. ábrán bemutatott grafikon - amelyet a Web of Science adatbázis alapján állítottam össze - is illusztrálja, a LIBS témájú publikációk száma évről évre intenzíven nő.



1-1. ábra: LIBS publikációk számának alakulása 1990-2010 között a Web of Science adatbázis alapján. 


\subsection{A LIBS készülékek részei}

Egy általános LIBS kísérleti elrendezést szemléltet az 1-2. ábra. A berendezés fő részei a következők:

(1) impulzusüzemű lézer;

(2) fókuszáló optika, amely a lézerimpulzus mintára való irányítását és fókuszálását végzi;

(3) mintatartó (általában $x-y-z$ irányban pozícionálható);

(4) fénygyűjtő optika, amely összegyűjti és a spektrométerbe juttatja a plazma által kisugárzott fényt;

(5) spektrométer (detektor);

(6) elektronika és számítógép, amely a detektor és a lézer szinkronizált indítását, illetve az emissziós spektrumok tárolását végzi.

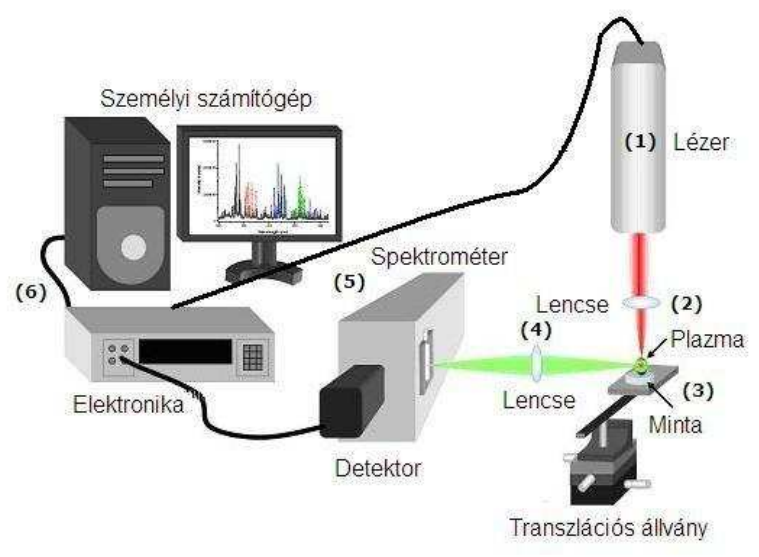

1-2. ábra: Általános LIBS kísérleti elrendezés.

Természetesen azonban az egyedi berendezések az alkalmazástól függően eltérhetnek egymástól. A müszerépítésnél a következő fontosabb tényezőket ajánlatos figyelembe venni: a vizsgálni kívánt elemek száma és minősége, a minta tulajdonságai (összetettsége, homogenitása, stb.), az analízis célja (kvalitatív vagy kvantitatív) és a minta halmazállapota (gáz, folyadék vagy szilárd). A technika fejlődése mára lehetővé tette a LIBS berendezésekben alkalmazott részegységek miniatürizálását, így a kutatóknak alkalma nyílt kisméretü, hordozható berendezések elkészítésére is [25, 26].

A LIBS műszerekben alkalmazott részegységek nem speciálisak, azok lényegében más lézeres atomspektroszkópiai berendezésben is megtalálhatók. A részegységek tárgyalása során ezért eltekintek a túlzott részletességtől és csak a legfontosabbak működési elvét, funkcióját ismertetem. 


\subsubsection{Lézer fényforrások}

A lézerműködés és az egyes lézertípusok részletes leírása számos szakkönyvben megtalálható [27-30], ezért itt ezekre a területekre nem térek ki.

A minták lézerrel való hatékony elpárologtatásához és a plazma létrehozásához nagy csúcsteljesítményre van szükség. Egy impulzusüzemű lézer sugárzásának impulzushossza rövidíthető, vagyis csúcsteljesítménye növelhető egy ún. Q-kapcsoló alkalmazásával. A Q-kapcsolós elrendezésnél a rezonátorban egy olyan optikai elemet helyeznek el, amely a sugárzás veszteségét okozza (abszorpció vagy reflexió révén), ami az erősítési tényezőt $(\mathrm{Q})$ lerontja mindaddig, amíg a populációinverzió egy meghatározott, nagy mértéket el nem ér. Ekkor ezt az optikai elemet eltávolítják vagy a sugárzás számára transzparenssé teszik, ami hirtelen megnöveli az erősítést és egy rövid idejü, s így nagy teljesítményű lézerimpulzus kibocsátását eredményezi. A LIBS spektroszkópiában tehát mindig Q-kapcsolós, nagy teljesítményü impulzusüzemű lézereket alkalmaznak. A legelterjedtebb típus a Q-kapcsolós Nd:YAG lézer, mivel kompakt, megbízható működésű, viszonylag olcsó és a laboratóriumi mérettől a kézben tartható, hordozható méretekig elkészíthető. Korábban a villanólámpás pumpálású, ma inkább a dióda lézerekkel pumpált Nd lézerek számítanak korszerűnek ezen a területen.

Az utóbbi években kezdenek elterjedni a mikrochip lézerek is. Ezek felépítésükben analógiát mutatnak a hagyományos szilárdtest lézerekkel, azonban jelentős közöttük a méretbeli különbség, így a mikrochip lézerek segítségével még tovább csökkenthető a hordozható kivitelben épülő LIBS berendezések mérete. További jellemzőik között érdemes megemlíteni, hogy (1) a mikrochip lézerek impulzusenergiája stabilabb; (2) a sugárnyaláb keresztmetszeti intenzitás profilja inkább Gauss jellegü, ami kisebb fókuszfoltot, így nagyobb térbeli felbontást tesz lehetővé a LIBS alkalmazásokban; (3) nagy ismétlési sebességgel rendelkeznek ( $\approx 10 \mathrm{kHz})$; (4) impulzushosszuk néhány száz ps, (5) impulzusenergiájuk mindössze a nJ- $\mu$ J tartományban van. Gornushkin és társai készítettek egy tanulmányt, amelyben egy passzív Q-kapcsolós, $7 \mu \mathrm{J}$ impulzusenergiájú, átlagosnak mondható Nd:YAG mikrochip lézernek a LIBS spektroszkópiában való alkalmazhatóságát vizsgálták [31]. Az általános tapasztalat szerint ezek a lézerek egyelőre csak nagymértékü fókuszálás esetén képesek LIB plazma keltésére. Kvantitatív analízisek sikeres elvégzéséhez nagyobb, legalább $50 \mu \mathrm{J}$ impulzusenergiával rendelkező, hasonlóan ps impulzushosszú lézerekre lenne szükség. Az ilyen mikrochip lézerek első példányai mára már kereskedelmi forgalomban is hozzáférhetők, ezért várható, hogy LIBS alkalmazásaik száma bővül majd. 


\subsubsection{A fókuszáló és fénygyüjtő optikai rendszer}

A LIBS rendszerekben a lézerimpulzusok mintára való fókuszálása és a plazmasugárzás spektrométerbe irányítása lencsékkel, tükrökkel vagy optikai szálakkal történhet. Az optikai rendszer kiépítése sok tényezőtől függ (pl. mintatípus, a lézer és a detektálandó sugárzás hullámhossza, lézer intenzitása, tárgytávolság, stb.), de azt minden esetben célszerű optimálni, mivel elrendezése az analitikai teljesítőképességet nagymértékben befolyásolja.

A fókuszáló rendszer feladata a lézernyalábot megfelelően kisméretű foltba fókuszálni (megfelelően nagy teljesítménysűrűséget létrehozni) az analitikailag hasznosítható plazma létrehozása céljából. Jellemzően ehhez egyetlen, fix fókusztávolságú szférikus gyűjtőlencsét (transzmissziós optika) használnak. Eppler és társai hengerlencsék alkalmazhatóságát is megvizsgálták és azt találták, hogy a hengerlencse által létrehozott vonalszerű fókuszfolt jobb precizitású LIBS mérési adatokat eredményezett; magyarázatuk szerint a fókuszfolt nagyobb területe miatt a minta inhomogenitása kevésbé érvényesül [32]. Természetesen a fókuszfolt nagyobb területe nagyobb lézer intenzitás alkalmazását igényli. Egyes speciális LIBS rendszerek esetében, amelyeknél szükség lehet állítható fókuszra (pl. olyan ipari gyártási folyamatok ellenőrzése, ahol a minta felszíne erősen korrugált vagy a lencse-minta távolság nagymértékben változhat), többlencsés optikai rendszert kell építeni és a lencsék helyzetét kell változtatni a fókuszpont megtalálásához ( $p l$. autofókusz elrendezés). A lézerfény fókuszálása történhet görbe felületű tükrök (reflektív optika) segítségével is. Ez azonban ritkán alkalmazott megoldás, mivel pl. a fémtükrök bevonatai igen sérülékenyek és könnyen károsodnak a nagy lézerintenzitás vagy az ablációs termékek hatására. Érdemes megemlíteni, hogy az igényes fókuszáló elrendezések egy nyalábtágító optikai eszközt is tartalmaznak a fókuszáló elem előtt, mivel ismeretes, hogy a szélesebb, a fókuszáló optikai elemet jobban kitöltő nyaláb jobban, kisebb foltméretre fókuszálható. Ezzel a konstrukcióval ráadásul a fókuszáló optikai elemet terhelő teljesítménysűrűség is csökken.

A legtöbb LIBS berendezésben a fókuszált lézersugár a mintafelszínre merőleges, vagy majdnem merőleges [33] irányból érkezik. A fókuszáló optika fókusztávolságával kapcsolatos gyakorlati szempontok közé tartozik, hogy annak elegendőan nagynak kell lennie ahhoz, hogy a minta felszínéből a plazmaképződés során nagy sebességgel kilökődő forró részecskék, olvadékcseppek az optikai elemben kárt ne tehessenek. Emiatt a gyakorlatban a fókusztávolság minimális értéke kb. $20 \mathrm{~mm}$. Hasonló gyakorlati megfontolások miatt pl. folyadékmintáknál a mintafelszín normálisához képest nagyobb (akár $75^{\circ}$ ) szög alatt való beesési szög alkalmazását javasolják, hogy a folyadékfelszínből többségében merőleges irányban távozó cseppek elkerüljék az optikát 
[34]. A LIBS berendezés építhető egy mikroszkóp köré is, ekkor a lézerfény fókuszálása (és a mintafelület megfigyelése) egyszerüen, de hatékonyan megoldható a mikroszkóp objektívje segítségével [35]. A fókusztávolságra vonatkozó feltételből ilyenkor az következik, hogy a szokásos mikroszkóp objektívek közül négyszeresnél nagyobb nagyítású nem használható.

A plazma által emittált fény gyűjtése általában szintén egyszerű optikai elemek (gyűjtőlencsék, tükrök) segítségével történik. Mivel a gyűjtendő spektrum hullámhoszsza széles tartományt fed le, ezért a lencsék esetében fellép az ún. kromatikus aberráció, ami a lencse hullámhosszfüggő fókusztávolságából adódó leképezési hiba (ezt az optikai anyagok törésmutatójának hullámhosszfüggése okozza). A látható tartományban ezt két vagy több, különböző alakú és törésmutatójú lencsékből álló lencserendszerrel hatásosan korrigálni lehet (akromatikus lencserendszer), azonban az UV tartományban (főként $300 \mathrm{~nm}$ alatt) ilyen megoldások nem léteznek. Természetesen az alkalmazott lencsék anyagának transzmissziója a detektálandó hullámhosszon a mért fényintenzitás érdekében nagyon jó kell legyen, ezért az UV tartományra való tekintettel leginkább kvarc lencséket alkalmaznak. A homorú tükrök alkalmazásának fő előnye, hogy fókusztávolságuk független a hullámhossztól, viszont beállításuk és tisztántartásuk nehézkesebb. Akár lencserendszert, akár tükröt alkalmazunk, a plazma emissziójának irányítatlansága miatt a nagyobb átmérőjü gyűjtő optika (nagyobb térszögű detektálás) alkalmazása nagyobb detektált jelet eredményez.

A fénygyűjtő rendszer geometriájára vonatkozóan kétféle megoldás terjedt el; a tengelyirányú (vagyis a beérkező lézernyaláb tengelyébe eső) és az oldalirányú, a plazmát a lézernyaláb tengelyével különböző (leggyakrabban kb. $45^{\circ}$ ) szöget bezáró irányban való megfigyelést végző elrendezés. A tengelyirányú megfigyelés kompaktabb és azzal az előnnyel jár, hogy a lencse-minta távolság kisebb hatással van a spektrális intenzitásokra és így pl. a mélységi elemzésekben ez az egyeduralkodónak nevezhető elrendezés [33]. Hátránya viszont, hogy ilyenkor a fókuszáló optikai elem azonos a fénygyűjtő optikai elemmel, aminek optimális kiválasztása/tervezése a sok LIBS rendszer esetében nagyon eltérő lézer- és detektálási hullámhosszak (pl. IR és UV) miatt nehéz feladat. Ezzel szemben a plazma oldalirányú megfigyelése jobban tervezhető, sokoldalúbb és adaptálhatóbb, de ugyanakkor a mintapozíció, a plazmajellemzők (hőmérséklet, elektronkoncentráció, stb.) változására érzékenyebb, ami nagyobb LIBS jelingadozásban jelentkezik. Számos tanulmány felhívta rá a figyelmet, hogy a plazma fényének térbeli integrálása a jel reprodukálhatósága szempontjából előnyös [pl. 33, 36, 37], ezért az egy gyüjtőlencsés megoldások sokszor jobb eredményeket produkálnak, mint a két vagy több gyűjtőlencsés (a plazmát pontszerű objektumként leképező, képalkotáshoz megfelelő) megoldások. 
Egy újabban igen elterjedt, mind a lézerfénynek a fókuszáló elemhez való vezetése, mind a plazma emisszió összegyűjtése során alkalmazható megoldás az optikai szálak használata. Az optikai szálak anyagának károsodása miatt („low damage threshold") kezdetben ezeket az eszközöket csak a plazma fényének gyüjtésére használták [26, 38]. Ma már kimondottan nagy intenzitású lézernyalábok vezetésére alkalmas száloptikai kábeleket is gyártanak. A száloptikák alkalmazásával kapcsolatban kétféle lehetőséget javasolnak a kutatók: két optikai szál használata (egyik a lézerfény „fókuszálására”, a másik a plazma fényének gyűjtésére) [39, 40], illetve a fókuszálás és fénygyűjtés egyazon szállal való kivitelezése váltott üzemmódban, vagy ún. bifurkált kivitelben [41, 42]. Rai és társai összehasonlították a lencsével és a száloptikával kivitelezett LIBS analitikai teljesítőképességét: a kísérleti körülmények optimálása után meghatározott kimutatási határok a vizsgált elemek nagy részére hasonló értékủek voltak [42]. Krasniker és társai száloptikák használatát javasolták a plazma különböző régióiból származó emisszió szimultán detektálására [43]. Az optikai szálak használata által kínált különleges előny, hogy a mérőrendszer és a minta egymástól nagy távolságban is elhelyezkedhet, amit pl. nehezen megközelíthető vagy veszélyes helyen található minták mérésekor lehet kihasználni (lásd 1.6. fejezet). Itt jegyezzük meg, hogy hagyományos "direktlátó" optika segítségével is demonstrálták, hogy több tíz méteres távolságból is lehetséges LIBS analízist végezni [44], azonban ilyenkor a kedvezőtlen térszög miatt a fénygyűjtés hatékonysága lecsökken és a kimutatási határok jelentősen emelkednek.

\subsubsection{A spektrométer és a detektor}

Mind a kereskedelmi, mind a kísérleti LIBS rendszerek esetében nagy változatosság tapasztalható a spektrométerek tekintetében. A spektrális érzékenység (és az ezzel összefüggő integrációs idő), a felbontóképesség, a széles dinamikus tartomány és az átfogott hullámhossztartomány a spektrométerek legfontosabb paraméterei. A más elemanalitikai müszerekben használatos spektrométerekhez képest a gyakorlatban használatos LIBS rendszerek spektrométereinek két megkülönböztető jellemzője, hogy 1) működésük időben pontosan (100 ns vagy nagyobb pontossággal) szinkronizált a plazmát keltő lézerimpulzussal és 2) detektor mátrix alkalmazásával az emissziós spektrum egy széles tartományban való szimultán felvételére képesek (pásztázó rendszerü spektrumfelvétel a néhány tíz $\mu$ s élettartamú letörési plazma megfigyelésekor nem lehetséges). Más tekintetben felépítésük főbb vonalakban megfelel az atomemissziós spektrométerekének; legfontosabb részegységük egy hullámhossz szelektív eszköz és az amögött elhelyezett érzékeny fotodetektor mátrix. 
Itt jegyezzük meg, hogy egyes laboratóriumi LIBS rendszerek esetében, amelyek fix hullámhosszon nagy időfelbontással dolgoznak, előfordulnak a kis sávszélességü interferencia szűrővel és egy fotoelektron-sokszorozóval megvalósított elrendezések is. A fényszűrőt ilyenkor úgy választják meg, hogy az a kérdéses spektrumvonal hullámhosszának megfelelő fényt engedje át a vonalszélességnek megfelelő sávszélességben. Ennek a megoldásnak a kis méret, tömeg, viszonylag alacsony ár és nagy sebesség az előnye, azonban valódi analitikai feladatokra nem alkalmasak, mivel nem kínálnak lehetőséget sem a spektrumok felvételére, sem intenzitás háttérkorrekció elvégzésére.

A LIBS spektrométerekben nagyon elterjedt a költséghatékony és jó teljesítőképességű Czerny-Turner polikromátor elrendezés, amelyben a fény egy belépő résen át egy homorú tükörre esik, amely a fényt kollimálja és egy forgatható diffrakciós rácsra vetíti. A komponenseire bontott fény ezután egy lineáris detektor mátrixra (fotodiódasor vagy $\mathrm{CCD}$ ) esik, amelyben minden fénykomponens detektálását egy másik detektor pixel végzi. Ma ezen a területen egyeduralkodónak számítanak a lineáris CCD detektorok, amelyek általában 1024, 2048 vagy 4096 pixelt tartalmaznak. A diffrakciós rácsok diszperziós jellemzőiből és a lineáris detektor elrendezésből adódóan ezen spektrométerek felbontása a lefedett hullámhossztartományban közel állandó, azonban viszonylag korlátozott. Például egy 2048 pixeles CCD detektorral ellátott, kb. 100 nm széles spektrumtartományt lefedő spektrométer (a szokásos belépő résszélességgel, pl. $10 \mu \mathrm{m}$ ) optikai felbontása 0.05-0.09 nm. Ez éppen csak elégséges a magas hőmérsékletű letörési plazma emissziós spektrumának felvételéhez, tekintettel a spektrumban található nagyszámú elemzővonalra.

Az igényesebb (és költségesebb) LIBS rendszerekben sok esetben találkozunk Echelle spektrométerekkel is (1-3. ábra). Ezek az eszközök nevüket a bennük alkalmazott ún. Echelle-rácsról kapták, ami egy nagy beesési szöggel rendelkező, magas interferencia-rendekben dolgozó speciális reflexiós rács. A szomszédos rendek közötti átfedés nagy lenne, ezért a rendek térbeli szeparációját egy másik, kereszt-diszperziós elemmel (általában prizma) oldják meg, amelynek diszperziós iránya merőleges az Echelle-rács diszperziós irányára, s így a rendekre merőleges irányban szétválasztja azokat, az eredmény pedig egy kétdimenziós spektrum, amelyet egy kétdimenziós detektor mátrixon (általában szintén $\mathrm{CCD}$ ) rögzítenek. Az Echelle spektrométerek jellegzetessége, hogy felbontásuk a hullámhosszúságtól függ; az UV-tartományban lényegesen jobb (1 pm körüli), mint a Vis tartományban (0.01 nm körüli). Összességében azonban a felbontás még így is lényegesen jobb, mint a Czerny-Turner elredenzésű polikromátoroknál, ami közvetlenül azzal van összefüggésben, hogy a detektor pixeleinek száma jóval nagyobb a lineáris detektorokénál (pl. 2048 x 2048). Az Echelle spektrométerek nagy hátránya az érzéketlenség; a nagy felbontás miatt az 
egyes detektor pixelekre ugyanis jóval kevesebb foton esik, mint a lineáris elrendezésnél.
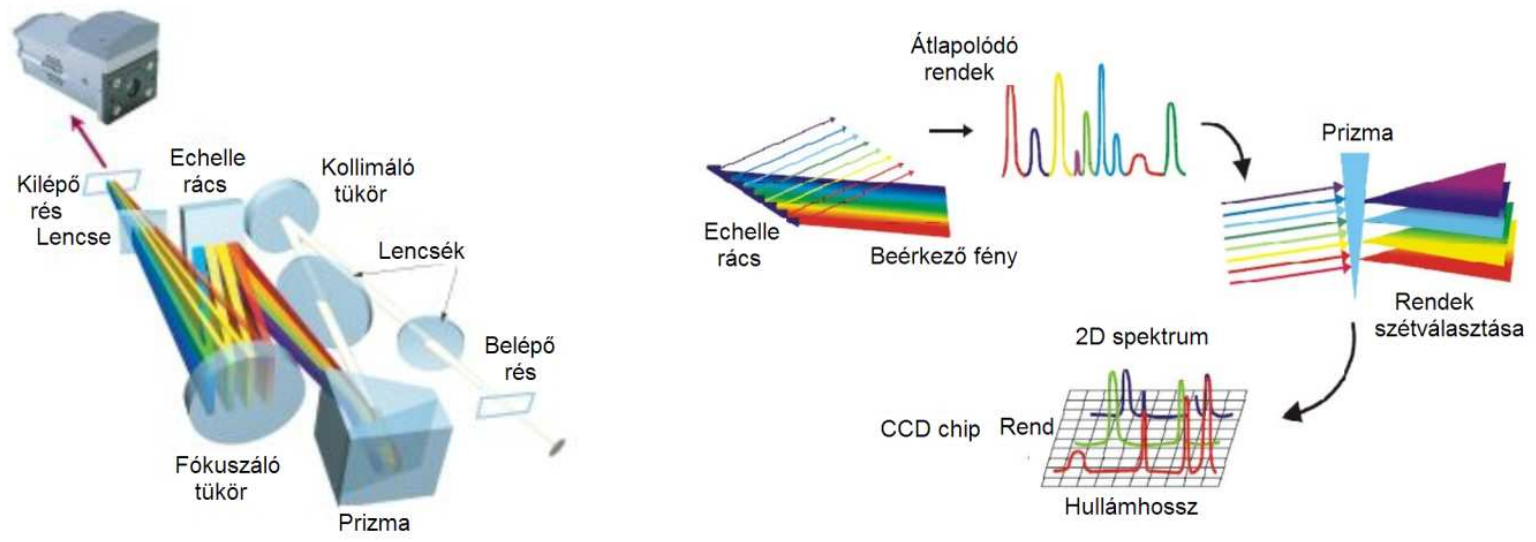

1-3. ábra: Echelle spektrométer felépítése és működése.

A LIBS spektrométerek tehát ma zömében CCD detektorokkal működnek. Ezen eszközök fényérzékeny félvezető elemeket tartalmaznak, amelyek a ráeső fényt szabályzott ideig integrálják, majd az egyes pixelekben a beeső fotonok hatására keletkezett és ott tárolt töltések mennyiségét szekvenciális elektronika segítségével kiolvassák. A CCD érzékenysége a még elfogadható jel/zaj viszony mellett tipikusan min. 0,01-1 ms integrációs idő használatát teszi lehetővé. Mivel a LIBS kísérletekben a gyors és időben pontosan szinronizált spektrométer (detektor) működés nagyon fontos, ezért ennél gyorsabb működésre (rövidebb integrációs időkre) is szükség lehet. Ezekben az esetekben ún. erősített CCD (intenzifikált CCD) detektorokat alkalmaznak. Ezekben az eszközökben a CCD detektor elé egy mikrocsatornás lemezt („microchannel plate”, MCP) és egy foszforernyőt helyeznek el (1-4. ábra). Az MCP lényegében egy nagyszámú, belső falán a fotoelektron-sokszorozók dinódáinak bevonataként alkalmazott, kis kilépési munkájú anyaggal bevont furatokat tartalmazó lemez. A MCP-re eső fotonok annak bekapcsolt állapotában ezekben a csatornákban nagyszámú elektronná konvertálódnak, amelyek a foszfor ernyőre való becsapódáskor lokalizált fénykibocsátást idéznek elő; ezt figyeli meg a CCD detektor. A lemez két oldala közötti potenciálkülönbség változtatása révén gyorsan és széles tartományban szabályozható az eszköz fényerősítése. Az iCCD detektorokkal elérhető a ns időfelbontás és kétdimenziós elrendezésük miatt ezek a detektorok érzékeny, nagysebességü kameraként is használhatók. 
(a)



(b)

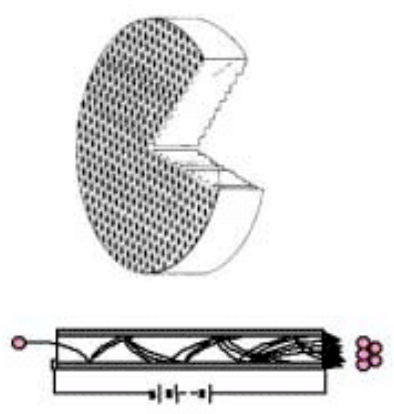

1-4. ábra: (a) Intenzifikált detektor felépítése és

(b) az MCP keresztmetszeti ábrája. 


\subsection{Lézer indukált plazma spektroszkópia (SP-LIBS)}

A LIBS folyamat során lejátszódó főbb lépéseket az 1-5. ábra szemlélteti. A lézerimpulzus beérkezése utáni első lépés a minta jelentős felmelegedése és az ennek következtében bekövetkező abláció, amely a minta lokális elpárologtatása/lebontása során lezajló részfolyamatok összefoglaló fizikai neve.

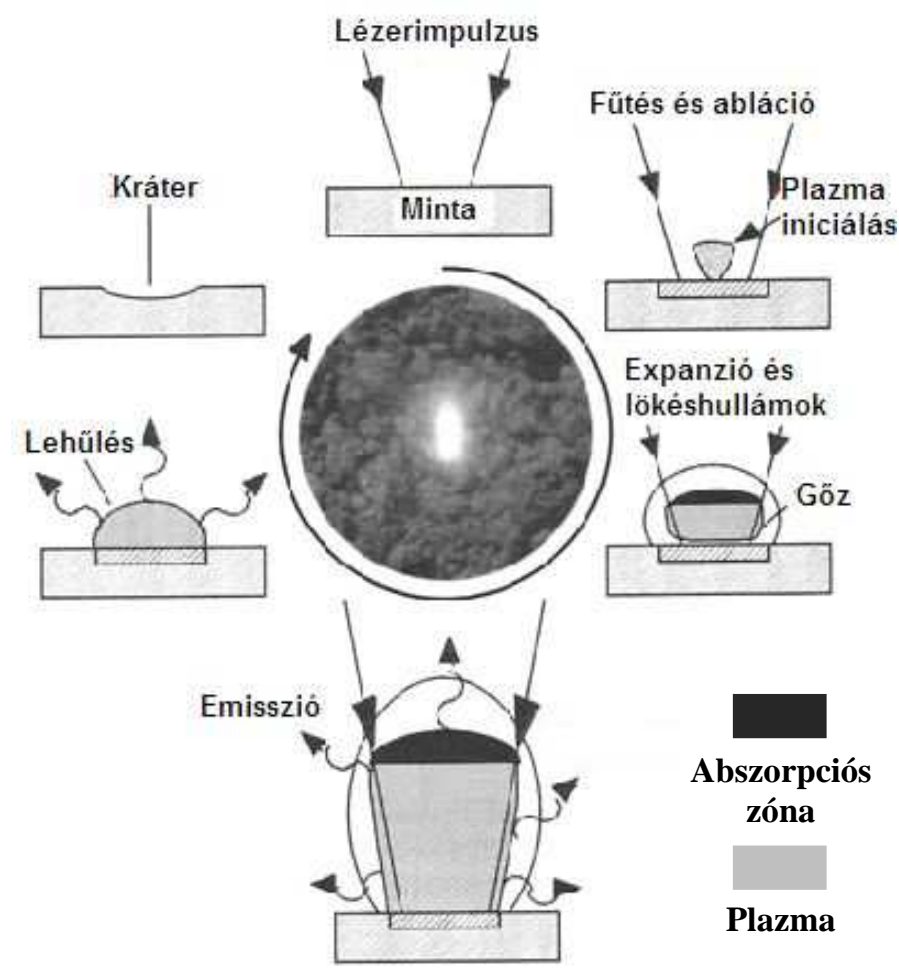

1-5. ábra: A LIBS folyamat során lejátszódó főbb lépések [45].

A lézeres ablációval kapcsolatban a szakirodalomban három küszöbérték fogalommal találkozhatunk:

(1) „damage" küszöbérték: az az energiasűrüség $\left(\mathrm{J} / \mathrm{cm}^{2}\right)$, amelyre ahhoz van szükség, hogy a mintafelületen optikai mikroszkóppal megfigyelhető változást hozzunk létre. Ilyenkor a mintafelület megolvad, megsérül, de anyageltávozás nem történik;

(2) ablációs küszöbérték: az az energiasűrüség, amelynél bekövetkezik az abláció, anyageltávozás. A céltárgyat elérő energia értéke egyenlő annak párolgási energiájával;

(3) plazmaképződési küszöbérték: az az energiasűrüség, amely a gőzfázis optikai lebontásához és letörési plazma keltéséhez szükséges. 
Magával a lézeres abláció jelenségeivel a fizika és az anyagtudomány foglalkozik. Az általuk használt lézerek energiája akkora, amely elegendő a minta lebontásához, vagyis az ablációs küszöbérték tartományában van, de az ablációt plazmaképződés nem kíséri.

Analitikai szempontból a lézeres abláció kétféleképpen hasznosítható. Az egyikben mintabeviteli módszerként szolgál szilárd halmazállapotú minták megfelelően érzékeny atomspektrométerekbe juttatására, lehetővé téve a közvetlen, mikropróbás szilárdmintás elemzést. A lézeres ablációt az ív- és szikraporlasztás egyik modern változatának is tekinthetjük. A másik alkalmazás a nagy teljesítménysűrüséggel létrehozott mikroplazma emissziójának megfigyelésén alapuló, önálló analitikai módszer, a LIBS.

Az ablációt követő letörési plazma kiterjedése és élettartama több paramétertől függ: az ablált anyag mennyiségétől és tulajdonságaitól, az elnyelt energia mennyiségétől, a lézersugár fókuszfoltjának méretétől, a lézerimpulzus hosszától és a környezettől (anyagi minőség, halmazállapot, nyomás). Ezen hatások tárgyalására az 1.3.1. fejezetben kerül sor. Atmoszférikus körülmények között az abláció (vagy plazmaképződés) során a mintát elhagyó gőzök és fragmentumok a környező gázban lökéshullámot hoznak létre, így a folyamatot jól hallható, éles, csattanó hang kíséri.

A lézerrel indukált plazma emissziós spektruma hőmérsékletével együtt az időben gyorsan változik. Ezt az időbeli fejlődést mutatja be az 1-6. ábra.



1-6. ábra: Az SP-LIBS fontosabb időbeli periódusai ( $t_{d}$ (késleltetési idő):

a plazma létrejötte és az adatgyűjtés megkezdése között eltelt idő;

$t_{b}$ (integrációs idő): az adatgyújtés időtartama) [45]. 
A plazma létrejöttét követő rövid időszakban (kb. $2 \mu \mathrm{s}$ ), a több tízezer Kelvin hőmérsékletű plazmában a szabad elektronok és az elemi ionok vannak többségben. Ebből eredően ebben az időszakban a plazma emissziós spektruma UV tartományba eső ionvonalakban gazdag és az alapvonal a szabad elektronok okozta fékezési sugárzás miatt emelkedett. Ha a spektrumot a lézerimpulzus beérkezésétől számított néhány $\mu \mathrm{s}$ vagy nagyobb késleltetéssel vesszük fel, amikorra a plazma már jelentősen (néhány ezer Kelvin hőmérsékletre) lehűlt, akkor inkább atomvonalakban gazdag, a fékezési sugárzástól nagymértékben mentes spektrumot rögzíthetünk. Nagyon hosszú késleltetési idő alkalmazása nyilvánvalóan nem célszerü, hiszen a plazmahőmérséklet rohamos csökkenésével a spektrumvonalak intenzitása is gyorsan csökken.

A leírtakat az 1-7. ábra illusztrálja, amely levegő LIBS-spektrumának (nitrogénés oxigénvonalak) időbeli változását mutatja be. Hasonlóak a tapasztalatok más halmazállapotú és összetételü minták esetében is. Analitikai célokra az elmondottak miatt leginkább a 3-10 $\mu$ s késleltetési idővel felvett spektrumok használatosak.

Amikor a plazma hőmérséklete a minta forráspontja alá csökken, az atomok elkezdenek kondenzálódni, nano- és mikrorészecskék képződnek, amelyek a keletkezett kráter körül rakódnak le. A részecskék méretét a lehűlés időtartama és a plazma sürüsége határozza meg. Az ICP-MS mérések és a nanotechnológia terén betöltött szerepe miatt jelenleg is számos kutatócsoport foglalkozik a részecskeképződés mechanizmusával [46-48]. A LIBS mérések során ez a folyamat általában az emissziós intenzitások csökkenéséhez vezet.

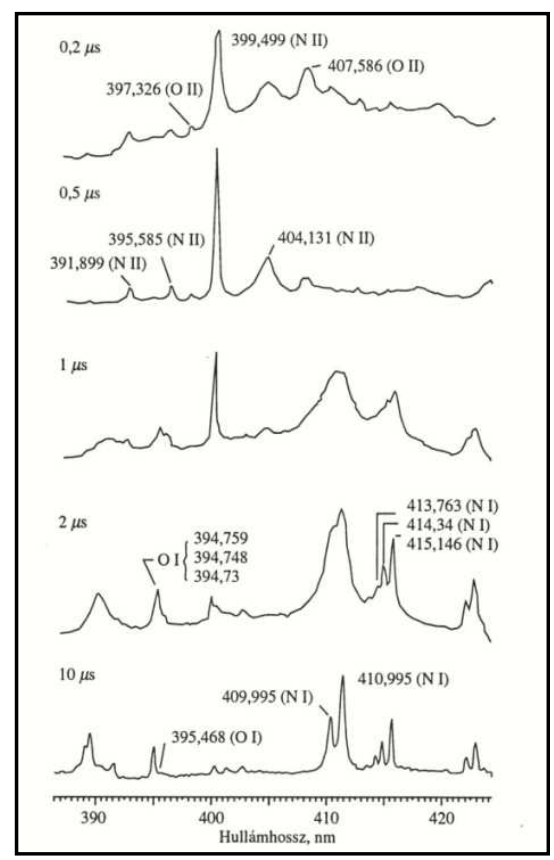

1-7. ábra: Levegő LIBS spektrumának alakulása a késleltetési idő függvényében [30]. 
A mintából ablált anyag mennyiségének jelentős része nem gőz, hanem részecskék formájában van jelen. A részecskeképződés történhet az elpárologtatott anyag kondenzációja, a minta folyadékállapotban lévő részének szétfröcskölődése és a szilárd mintarész felpattogzása révén. Az így keletkezett részecskék nem járulnak hozzá az analitikai jelhez, hacsak a plazma maga újra el nem párologtatja és gerjeszti azokat. A LIBS készülékekben a lézerfény paramétereit célszerü úgy megválasztani, hogy lehetőség szerint minél inkább elkerülhető legyen ez a folyamat.

\subsubsection{Az ablációt befolyásoló paraméterek}

A lézeres abláció folyamata során összetett, nem lineáris jelenségek játszódnak le, amelyek a lézer és a minta tulajdonságaitól függnek. Ezeknek a paramétereknek a kísérleti elválasztása és a hatásuk külön-külön történő vizsgálata nagyon bonyolult. Ebben a fejezetben egy általános, áttekintő leírást törekszem adni ezen paraméterekről és az ablációra gyakorolt hatásukról. A különböző kutatócsoportok által publikált eredmények összehasonlítása azonban nagyon nehéz, mivel az egyes kísérleti berendezések paraméterei jelentősen eltérnek.

A lézeres abláció során lejátszódó mechanizmusok elsődlegesen a lézer teljesítménysűrűségétől (teljesítmény/egységnyi terület) függnek. Általánosan elmondható, hogy az alacsony intenzitású nanoszekundumos lézerimpulzusok alkalmazása során a termikus elpárologtatás a domináns folyamat. A pikoszekundumos és a nagy intenzitású nanoszekundumos impulzusok esetében mind termikus és nem termikus folyamatok is jelen vannak. A nagyintenzitású femtoszekundumos impulzusok során a Coulomb robbanás az elsődleges ablációs mechanizmus [93]. Ezek miatt azt lehet mondani, hogy a kísérleti körülmények definiálásához a legfontosabb paraméterek az impulzushossz és a teljesítménysűrüség. További paraméterek, amelyeket hasznos figyelembe venni: a lézer hullámhossza, sugárnyaláb keresztmetszeti intenzitás profilja és ismétlési sebessége. Jelentős hatással bírnak a környező gáz minősége, nyomása és a minta fizikai és kémiai tulajdonságai is.

A különböző folyamatoknak - amelyek meghatározzák a képződő plazma tulajdonságait (hőmérséklet és elektronsürüség), valamint az ablált anyag mennyiségét eltérő energia- és teljesítménysűrűség küszöbértékük van [49-51]. A lézer energiájának hatását egymagában meglehetősen bonyolult lenne tanulmányozni. Általánosan elmondható, hogy azonos impulzushossz és fókuszfolt méret mellett az ablációs ráta (ablált anyag mennyisége/lézerimpulzus) növekszik a lézerenergia növelésével.

Russo és társai több tanulmányt is publikáltak a lézerenergia ablált tömegre gyakorolt hatásával összefüggésben [52-54]. Nanoszekundomos impulzushosszú 
lézert alkalmazva azt tapasztalták, hogy a teljesítménysürüséget egy bizonyos értékig $\left(\approx 0,3 \mathrm{GW} / \mathrm{cm}^{2}\right)$ növelve meredeken, de közel lineárisan növekszik az ablált anyagmennyiség. A teljesítménysűrűség további növelésével a növekedés nem áll meg, de a görbén egy kisebb meredekségű szakasz következik (1-8. ábra). A jelenség a plazmaárnyékolás („plasma shielding”) következménye, azaz ha a plazma elér egy kritikus sürüséget, a lézersugárzás későbbi része részlegesen elnyelődik benne, mielőtt elérné a minta felszínét.

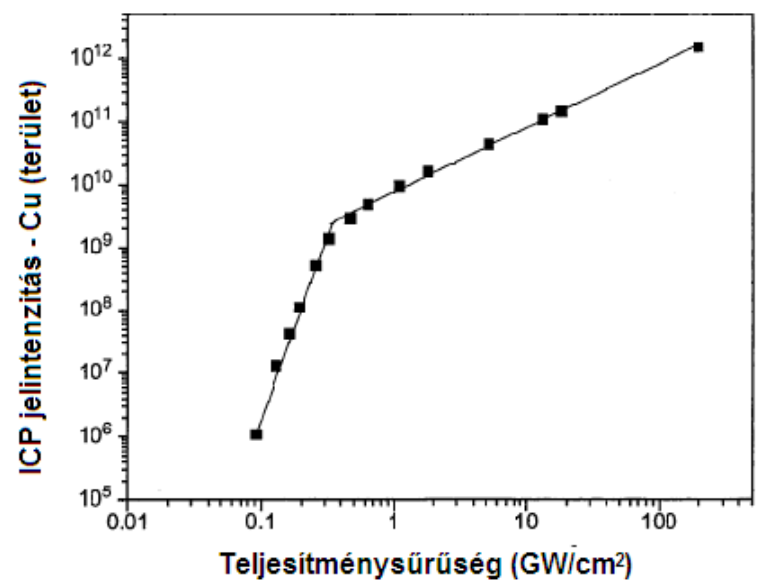

1-8. ábra: Az ablációs ráta változása a teljesítménysűrűség függvényében [52].

Az ablációs ráta kísérleti paraméterektől (teljesítménysűrűség, impulzushossz, mintafelszín tulajdonságai) való függésének atmoszférikus nyomáson történt vizsgálatai azt mutatják, hogy általában az ablált anyag mennyisége növekszik a teljesítménysürüség növelésével és a rövidebb impulzusok (ps, fs) nagyobb mennyiségű anyagot ablálnak, mivel nem lép fel plazmaárnyékolás. A lézerimpulzus energiájának a mintában hővezetés révén elveszített része kisebb a rövidebb impulzusok esetében [54-56].

Ha a lézer impulzushossza a nanoszekundum nagyságrendbe esik és teljesítménysürüsége elég nagy $\left(>10^{8} \mathrm{~W} / \mathrm{cm}^{2}\right)$, a termikus folyamatokkal egyidőben nemtermikus folyamatok is felléphetnek. Az impulzus időtartama alatt a minta felszínének hőmérséklete emelkedik, végül megolvad és elpárolog. Az elpárolgott anyag elnyeli a beérkező lézersugárzást, ezáltal ionizálódik és plazma képződik. Ha a plazma elér egy kritikus sűrűséget, fellép a plazmaárnyékolás jelensége, amelyet Mao és Russo tanulmányoztak lézerimpulzusok transzmittált és reflektált időbeli profiljának segítségével [52]. Alacsony teljesítménysűrüségeknél a transzmittált impulzusok profilja hasonló volt az eredeti impulzus profiljához, de 0,3 $\mathrm{GW} / \mathrm{cm}^{2}$ teljesítménysürüség felett a lézerimpulzus későbbi része csonka volt.

Az analitikai alkalmazásokban - különösen a LIBS berendezésekben - a leggyak- 
rabban a nanoszekunumos impulzushosszú lézereket alkalmazzák. Ezen lézerek analitikai teljesítőképességét (a hullámhossz, az energia, az ismétlési sebesség, a környező gáz, az impulzusszám hatása) több kutatócsoport is megvizsgálta már [57-59].

A pikoszekundomos lézerimpulzusokkal kivitelezett lézerabláció során a lézer teljesítménysűrűségétől függően a rács termikus és/vagy nemtermikus folyamatok révén olvadhat meg. Az impulzus időtartama alatt elektronok lépnek ki a minta felszínéről. A szabad elektronok kölcsönhatásba lépnek a levegővel és lézerenergiát abszorbeálnak, így az impulzus időtartama alatt egy levegőplazma keletkezik, sokkal hamarabb, mint ahogy anyag távozik a mintából. Ez a levegőplazma a beérkező lézersugár egy részét elnyeli, tehát ebben az esetben is fellép a plazmaárnyékolás, de ellentétben a ns tartományú esettel, itt nem a mintából képződött plazma abszorbeál.

A femtoszekundumos lézerimpulzusokkal előidézett lézerablációt egy közvetlen szilárd-gőz (vagy szilárd-plazma) átmenetnek tekinthetjük. A lézerimpulzus időtartama alatt a mintában a hővezetés elhanyagolható.

Chichkov és társai fs, ps és ns hosszúságú impulzusokkal létrehozott kráterek morfológiai jellemzőit hasonlították össze [60]. Eredményeiket az 1-9. ábra szemlélteti. Egyértelműen megfigyelhető, hogy a fs időtartamú lézerimpulzussal keletkezett kráter rendelkezik a legjobban definiált alakkal, elhanyagolható a kráter köré visszarakódott anyag mennyisége, valamint az is jól látszik, hogy a mintában valóban elhanyagolható a hővezetés (kevés dilatációs gyűrű). Tehát ez az impulzushossz a legmegfelelőbb, ha lézeres anyagmegmunkálásról van szó, továbbá a hőveszteség hiánya miatt alacsonyabb lézer teljesítménysürüség mellett hozhatók létre a megfelelő mélységű kráterek.

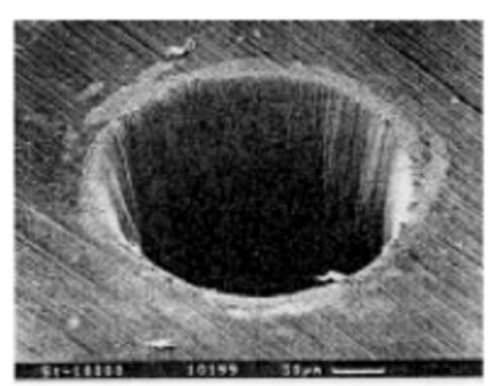

a)

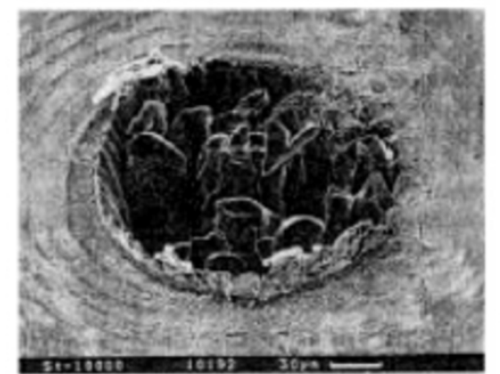

b)

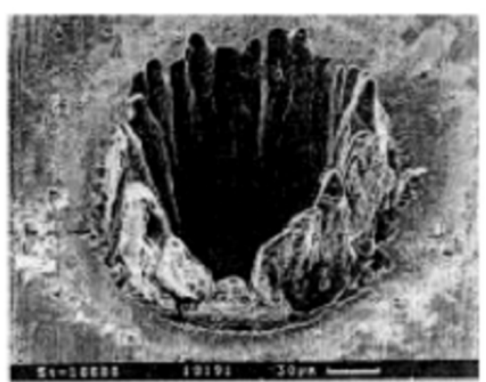

c)

1-9. ábra: Különböző impulzushosszú lézerekkel $(\lambda=780 \mathrm{~nm})$, acélmintákon létrehozott kráterek SEM felvételei (a) $200 \mathrm{fs}, 120 \mu \mathrm{J}, \mathrm{F}=4,2 \mathrm{~J} / \mathrm{cm}^{2}$ ，(b) $80 \mathrm{ps}, 900 \mu \mathrm{J}, \mathrm{F}=3,7 \mathrm{~J} / \mathrm{cm}^{2}$, (c) $3,3 \mathrm{~ns}, 1 \mathrm{~mJ}, \mathrm{~F}=4,2 \mathrm{~J} / \mathrm{cm}^{2}$ [60].

Eland és társai is végeztek összehasonlító vizsgálatokat pikoszekundumos és nanoszekundumos lézereket alkalmazva [55]. Azt tapasztalták, hogy az ablált anyag- 
mennyiség reprodukálhatósága sokkal jobb volt pikoszekundumos lézer esetében. A kráterekről készült SEM felvételeken ők is megfigyelték, hogy a pikoszekundumos lézerrel létrehozott kráternél kevésbé olvadt meg és roncsolódott a minta, valamint a kráter körüli anyaglerakódás is csekélyebb volt. A LIBS spektrum jel/zaj viszonya is sokkal jobb volt a rövidebb impulzushossz esetén. A plazma térfogata kb. egy nagyságrenddel nagyobb volt a nanoszekundumos esetben, mivel az impulzus későbbi része újrahevítette azt. Arra a következtetésre jutottak, hogy az impulzushosszakban lévő különbségek ellenére a lejátszódó mechanizmusok körüli zűrzavar nagymértékben az energiasűrűségbeli eltéréseknek köszönhető.

Le Drogoff és munkatársai az emissziós vonalak időbeli fejlődését vizsgálták különböző impulzushosszak alkalmazásával [61]. Azt tapasztalták, hogy a plazma hőmérséklete nő az impulzushosszal, míg az elektronsűrűség relatíve állandó marad az általánosan használt késleltetési időknél. Az 5 pikoszekundumnál hosszabb impulzusok esetében fellép a lézer-plazma kölcsönhatás, amely a plazma újrahevítését eredményezi. Ezért ahogy az impulzushossz femtoszekundumról nanoszekundumra nő, a plazma élettartama hosszabb lesz. Ezt a jelenséget néhány évvel később Russo és társai is megfigyelték [56]. A korai szakaszban ( $<30 \mathrm{~ns}$ ) a femtoszekundumos plazma emissziójának intenzitása csökken, míg a nanoszekundumos plazmáé egy ideig növekszik, mivel a lézerimpulzus későbbi részének a plazma általi abszorpciója újrahevíti a plazmát. Sirven és munkatársai is hasonló megfigyeléseket tettek [62]. A fs és ns impulzushossz esetében hasonló volt az emissziós intenzitás, kivéve a korai szakaszban. A nanoszekundumos impulzus esetében a háttér kb. háromszor magasabb volt.

Russo és társai 266 nm-es, ns és fs impulzushosszú lézerekkel, szilícium mintán létrehozott kráterek mélységét hasonlították össze [56]. Mindkét impulzushossz esetén az impulzusszám növelésével lineárisan nőtt a kráterek mélysége, azonban a femtoszekundumos impulzushossz esetén azonos impulzusszámnál és energiasűrüségnél kb. kétszer mélyebb krátereket kaptak. Megvizsgálták továbbá acélmintákon keltett plazmák időbeli alakulását árnyékkép ("shadowgraph”) technikával. Látható az 1-10. ábrán, hogy a femtoszekundumos lézerrel létrehozott plazma a kezdeti szakaszban csak a mintafelszínre merőleges irányban terjed ki, a laterális növekedés csak nanoszekundumos időskálán kezdődik meg lassan. A nanoszekundumos lézer által keltett plazma a kezdetektől fogva mindkét irányba növekszik, hasonló sebességgel és a mérete jelentősen nagyobb. 



$100 \mu \mathrm{m}$

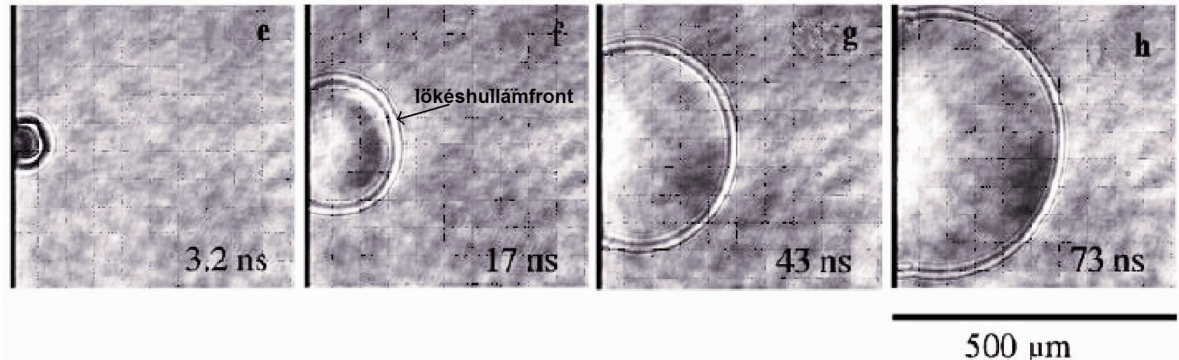

1-10. ábra: Fs (a-d) és ns (e-h) impulzushosszú lézerekkel létrehozott plazmák árnyékkép ("shadowgraph") felvételei különböző időpillanatokban [56].

A lézer hullámhosszának hatása két szempont szerint tárgyalható: a lézer-anyag kölcsönhatás és a plazma fejlődése.

A lézer-anyag kölcsönhatás: a rövidebb hullámhosszak nagyobb foton energiát nyújtanak a kötéshasadási és ionizációs folyamatok számára. Például a 193 nm-es hullámhossz 6,4 eV foton energiát szolgáltat, míg az 1064 nm-es 1,16 eV-ot. A legtöbb anyag kötési energiája néhány eV. Ha a foton energia magasabb a kötési energiánál, fotoionizáció történik és a nem termikus folyamatok játszanak fontos szerepet az abláció során. Továbbá az UV tartományba eső hullámhosszak optikai penetrációs mélysége kisebb, így az ablációhoz egységnyi felületre nagyobb energia jut. Általánosan elmondható, hogy a rövidebb hullámhosszak esetén nagyobb az ablációs ráta, amely indirekt módon jelzi a lézerenergia és a céltárgy közötti csatolás hatékonyságát is, valamint növeli a mérés térbeli (laterális és mélységi) felbontását.

Günther és társai tanulmányozták a lézer hullámhosszának ablációs rátára való hatását [63]. Fém- és üvegmintákat vizsgáltak egy 266 nm-es Nd:YAG és egy 193 nm-es excimer lézert használva. Azt tapasztalták, hogy az ablációs ráta az alacsony abszorbanciával rendelkező anyagoknál függött a lézer hullámhosszától. Az üvegmintáknál különböző volt az ablációs ráta a 266 nm-es lézerrel, amit különböző hatékonyságú lézer-minta kölcsönhatás eredményezhet. A 193 nm-es lézert használva a három üvegminta esetében hasonló volt az ablációs ráta, az optikai behatolási mélység pedig meglehetősen alacsony volt. 
A plazma fejlődése és tulajdonságai szintén függnek az alkalmazott lézer hullámhosszától.

Laserna és társai fémminták plazmaképződési küszöbértékeinek hullámhossz függését tanulmányozták [64]. Annak ellenére, hogy a lézerenergia becsatolása sokkal hatékonyabb a rövidebb hullámhosszakon, a küszöbérték nagyobbnak adódott egy 266 nm-es lézert egy 532 nm-es és egy 1064 nm-es lézerrel összehasonlítva. Ezek a megfigyelések összhangban vannak a plazma inverz fékezési sugárzás általi képződésének feltételezésével, amely szerint az inverz fékezési sugárzás abszorpciós koefficiense $\lambda^{3}$-nal arányos, így sokkal kedvezőbb IR hullámhosszak esetén.

Amikor jelen van az inverz fékezési sugárzás, a lézersugár egy része a plazma melegítésére fordítódik. A plazma újrafútése növeli annak élettartamát és az emissziós vonalak intenzitását, amely kedvező a LIBS mérések számára, habár a háttér emisszió szintén növekedhet. A teljes mechanizmus megismeréséhez még további alapos kutatások szükségesek. Nagy energiasűrüségeknél jelentős a plazmaárnyékolás, amelynek kedvez a hosszabb hullámhossz, de ebből eredően alacsonyabb az ablációs ráta [65, 66]. Általánosan elmondható, hogy a legtöbb LIBS tanulmány során 1064 nm-es Nd:YAG lézereket alkalmaznak, míg az LA-ICP-MS mérések legtöbbje az Nd:YAG lézerek negyedik vagy ötödik harmonikusán (266 vagy $213 \mathrm{~nm}$ ) alapul.

A lézer indukált plazma (LIP) mérete, kiterjedésének sebessége, stabilitása, energiája és emissziós tulajdonságai nagymértékben függnek a környező közegtől, amelyben a plazma képződik és kiterjed. Több kutatócsoport is foglalkozott a plazma tulajdonságainak vizsgálatával a környező gáz minőségének és nyomásának függvényében [67-71], valamint folyadékokban [71-73]. A környező gáz egyaránt segítheti vagy akadályozhatja a lézerenergia plazmába való csatolását. Például a környezet árnyékolhatja a mintafelszínt (plazmaárnyékolás), ha előbb történik a gázban letörés („breakdown"), mint hogy a minta elpárologna. A környező gáz a plazma sugárzását is kiolthatja azáltal, hogy az ütközések révén a plazma gyorsabban hül le; levegőben rövidebb élettartamú és alacsonyabb hőmérsékletű plazmát figyeltek meg, mint argonban [74]. Ezt a megfigyelést az argon levegőnél kisebb vezetőképességével és fajhőjével magyarázták.

Wisbrun és társai azt tapasztalták, hogy az argon atmoszféra kedvezőbb mind a jelintenzitás, mind a reprodukálhatóság szempontjából, valamint hogy a környező gáz atomtömegének növekedésével az ütközéses transzlációs energiatranszport hatása kevésbé jelentős és a plazma élettertama növekszik [75].

Sdorra és Niemax atmoszférikus nyomásnál kisebb nyomású argon, neon, hélium, nitrogén és levegő plazmaképződésre gyakorolt hatását vizsgálta azonos kísérleti körülmények között [76]. Azt tapasztalták, hogy az argonban képződött plazma a legmagasabb hőmérsékletű, a legnagyobb elektronsűrűségű, ennek ellenére itt volt a 
legkisebb az ablációs ráta, valamint a kiválasztott elemek vonalaira ez a plazma szolgáltatta a legnagyobb intenzitást. Továbbá a hőmérsékletcsökkenés sebessége a lé-

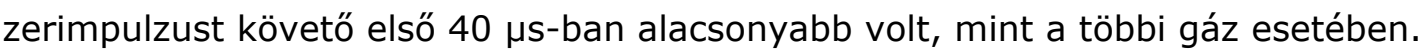

Ezek az ellentétes hatások valószínüleg kevésbé fontosak gáz vagy aeroszol minták esetén, de hatásuk lényeges szilárd mintáknál, úgymint lecsökkent ablációs ráta (plazmaárnyékolás), magasabb folytonos háttéremisszió és rövidebb plazmaélettartam. A környező gáz szintén elősegítheti a plazma lassabb kiterjedését és minimalizálhatja a atmoszférikus elemek háttéremisszióját. Bizonyos esetekben, amikor a spektrumot 100-200 nm-es tartományban rögzítjük, inert gáz használatával elkerülhetjük az oxigén molekulák abszorpcióját [77].

A környező gáz nyomása is befolyásolja a plazma kiterjedését és az emissziós vonalak intenzitását. Alacsony nyomáson ( $<1$ mbar) a plazma majdnem teljesen szabadon terjed ki és külső része az energiaveszteség miatt alacsonyabb hőmérsékletűvé válik. 1 mbar-nál magasabb nyomáson az energiaveszteség csökken és egy sokkal egységesebb energiaeloszlás valósul meg a plazmában. Különböző nyomású és anyagi minőségű gázok különböző hatást fejtenek ki.

Iida azt tapasztalta, hogy a vas 374,95 nm-es vonalának intenzitása 760 torr nyomáson héliumban nagyobb volt, mint levegőben és argonban, azonban a nyomást 100 torr-ra csökkentve az intenzitás 10-szeresére növekedett argonban és 2-3szorosára levegőben (1-11. ábra). Megfigyeléseit azzal magyarázta, hogy argonban sűrűbb plazma képződik, mint héliumban [78].

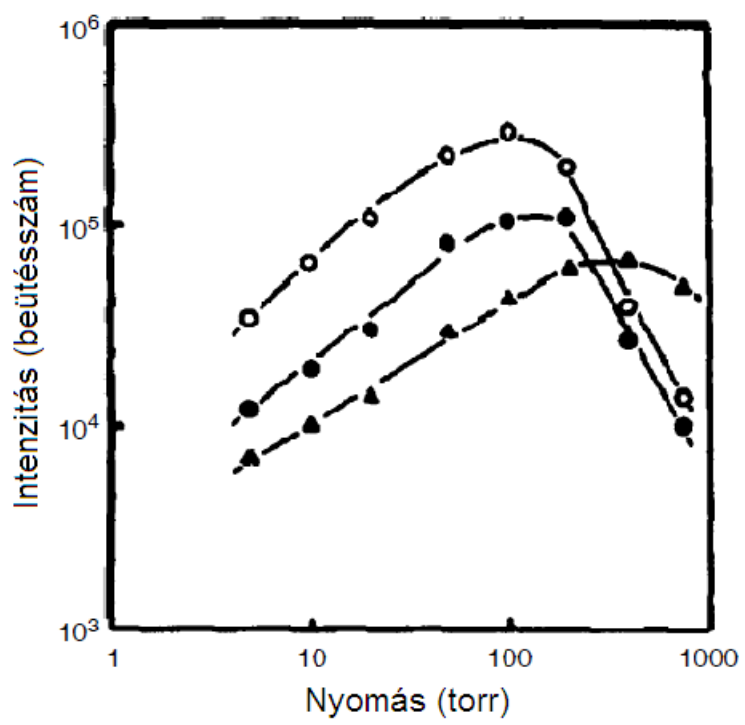

1-11. ábra: $A$ Fe(I) 374,95 nm-es vonalának intenzitásváltozása a környező gáz anyagi minőségének és nyomásának függvényében ( $\bigcirc$-argon, •-levegő, $\boldsymbol{\Delta}$-hélium). Minta: standard Al ötvözet 0,97\% vastartalommal [78]. 
Általános tapasztalat, hogy csökkentett nyomáson a plazma mérete növekszik. $10^{-3}$ torr alatti nyomáson jelentős csökkenés következik be a jelintenzitásban, amely az ütközéses gerjesztődés csökkenésének következménye. A plazma vákuumban való szabad kiterjedése (rövid élettartam) előnytelen a LIBS mérések során. Számos LIBS tanulmány készült nagy nyomású körülmények között is.

Noda és társai szálló hamu, faszén és porított szén széntartalmát határozták meg sikeresen nagynyomású és magas hőmérsékletü üzemi körülmények között [79]. Az ilyen szélsőséges körülmények között elvégezhető méréseknek szintén jelentős szerepe van az in-situ geokémiai vizsgálatok során, pl. mélytengeri és vulkáni mérések, vagy éppen más bolygókon történő analízisek [80, 81].

A nagynyomású környezet által okozott hátrányok a spektrumvonalak kiszélesedése és az önabszorpció, amely jelenségek korlátozzák a LIBS használhatóságát.

Nyga és társai is tapasztalták ezen hatásokat víz alatti minták mérésénél (1-12. ábra) [73]. A vonalkiszélesedés és a jelcsökkenés kiküszöbölésére a kétimpulzusos LIBS módszer használatát javasolták. Véleményük szerint a két impulzussal elérhető javulás abból ered, hogy az első impulzus egy buborékot hoz létre a mintafelszín felett, így a második impulzus már egy gázból álló környezetbe érkezik.

Arp és társai a Vénusz bolygón uralkodó körülményeket szimulálva 90 atm nyomású nitrogén és 56 atm nyomású szén-dioxid környezetben végeztek LIBS méréseket. Azt tapasztalták, hogy míg néhány vonal mutat vonalkiszélesedést és önabszorpciót, addig más vonalak mentesek ezen hatásoktól [80].
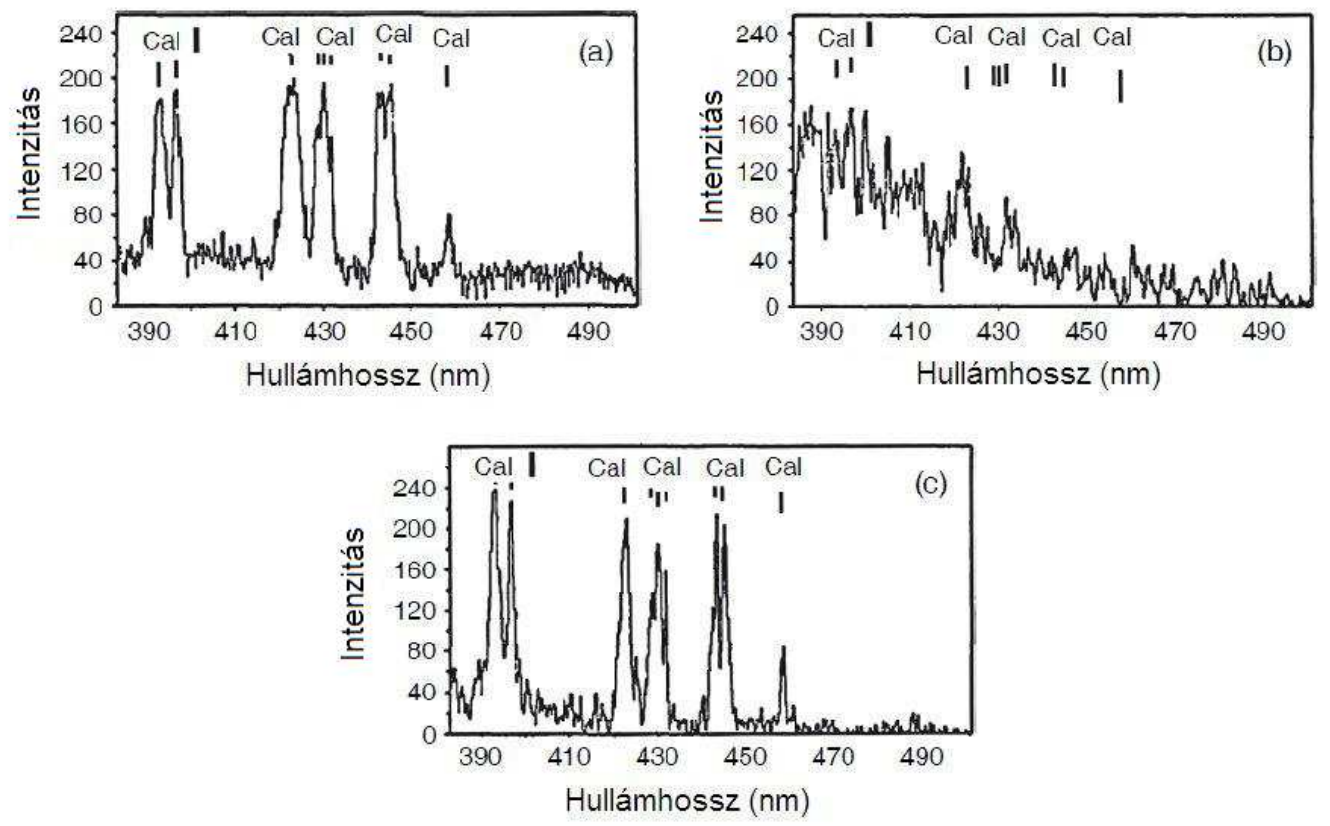

1-12. ábra: Kalcit emissziós spektruma (a) levegőben, (b) víz alatt 1 impulzussal és (c) víz alatt 2 impulzussal [73]. 


\subsubsection{A LIBS, mint analitikai módszer}

\subsubsection{Analitikai jellemzés}

A LIBS-szel a periódusos rendszer majdnem minden eleme detektálható és szimultán multielemes analízis lehetséges. Mivel a lézerimpulzust optikai elemekkel fókuszáljuk a minta felületére és a keletkezett fényemissziót is optikai úton gyűjtjük be, így nincs szükség közvetlen kontaktusra sem a mintával, ami a LIBS módszert egyedi analitikai előnyökkel ruházza fel, pl. távolról történő méréseket tesz lehetővé. Összefoglalóan a LIBS módszert a főbb analitikai előnyök tekintetében az alábbi listával lehet jellemezni:

- egyszerüség,

- gyors (közel valós idejű) elemzés,

- mintaelőkészítés nem szükséges,

- a vizsgált rendszer megzavarása nélküli (in-situ, nem destruktív) analízis lehetősége,

- gáz, folyadék és szilárd halmazállapotú, alaktalan minták is vizsgálhatók,

- jó érzékenység a más módszerekkel rosszul detektálható elemekre (pl. halogének),

- többféle mérési üzemmód (pl. terepi, távoli, laboratóriumi) lehetősége,

- robusztus, szélsőséges körülmények között is működő plazmaforrás.

Érdemes kiemelni, hogy a LIBS méréseket megelőzően - szemben a legtöbb más atomspektrometriai módszerrel - általában semmilyen mintaelőkészítés nem szükséges, hiszen nem kell a mintát oldatba vinni, de legtöbbször még méretre vágni sem szükséges a szilárd mintákat, ami időt, energiát és vegyszert kímél. A LIBS-hez részben hasonló, lézerablációs mintabeviteli módszerhez (pl. az elterjedt LA-ICP-MS kivitelhez) képest is van több előnye; olcsóbb, egyszerűbb, akár terepi mérésekre alkalmas és zavaró transzport folyamatoktól mentes mérést biztosít. A LIBS mintaelőkészítés szilárd mintáknál általában arra korlátozódik, hogy a mérések előtt egy ún. tisztító lövést alkalmazunk a mintafelületen (pl. oxidréteg, felületi szennyeződések eltávolítása), esetleg alkohollal, acetonnal letöröljük a szilárd minta felszínét.

$\mathrm{Az}$ analízis sebessége igen nagy, hiszen mintaelőkészítésre gyakorlatilag nincs szükség, a plazma pedig rövid élettartamú (néhány $10 \mu \mathrm{s}$ ), vagyis egy LIBS mérés (egyszeri lövés a mintafelületre és a spektrum rögzítése) tulajdonképpen mindössze néhány másodpercet igényel. A tapasztalatok azonban azt mutatják, hogy megbízható eredmények eléréséhez több ismételt mérésre van szükség, mivel a spektrális intenzitások szórása, ismételhetősége általában 10-20\% körüli. Az analitikai teljesítményjellemzők (pontosság, precizitás, kimutatási határ) a LIBS módszernél a mintaelőkészítés 
hiánya miatt sokkal inkább függnek a minta tulajdonságaitól, mint az oldatos atomspektroszkópiai módszereknél.

Az 1-1. táblázatban a LIBS módszerrel elérhető jellemző kimutatási határok láthatók néhány elemre, különböző mátrixokban. A táblázatot áttekintve látható, hogy igen eltérő kimutatási határok szerepelnek ugyanazon elemekre. Ennek egyik oka a mátrixok különbözősége, de az egyes irodalmi forrásokban használt kísérleti paraméterek (pl. a lézerimpulzus energiája, a mérések száma, atmoszféra, optikai rendszer, stb.) is nagymértékben befolyásolják az eredményeket.

Halmazállapot / Mátrix

\begin{tabular}{|c|c|c|c|}
\hline Elem & Gáz (ppm) & Folyadék (ppm) & Szilárd (ppm) \\
\hline $\mathrm{Al}$ & & $20[82]$ & $\begin{array}{l}54 \text { (üveg, } 1 \text { Torr) [84] } \\
130 \text { (vasérc) [85] }\end{array}$ \\
\hline $\mathrm{Be}$ & 0,0006 (aeroszol) [16] & $10[82]$ & $9[26]$ \\
\hline $\mathrm{K}$ & & $1,2[82]$ & 190 (üveg, 1 Torr) [84] \\
\hline $\mathrm{Li}$ & & $\begin{array}{l}0,006[82] \\
0,013[83]\end{array}$ & 10 (üveg, 1 Torr) [84] \\
\hline $\mathrm{Mg}$ & & $100[82]$ & $\begin{array}{c}\text { 0,5 (alumínium ötvözet) [86] } \\
130 \text { (üveg, } 1 \text { Torr) [84] } \\
230 \text { (vasérc) [85] }\end{array}$ \\
\hline $\mathrm{Na}$ & 0,006 (aeroszol) [16] & $\begin{array}{c}0,0075[83] \\
0,014[82]\end{array}$ & 14 (üveg, 1 Torr) [84] \\
\hline $\mathrm{Pb}$ & & $12,5[83]$ & $\begin{array}{c}10 \text { (talaj) [75] } \\
50 \text { (talaj) }[87] \\
298 \text { (talaj) }[26] \\
17 \text { (homok) }[32] \\
10 \text { (beton) }[88]\end{array}$ \\
\hline
\end{tabular}

1-1. táblázat: Jellemző kimutatási határok néhány elemre különböző mátrixokban.

Az 1-2. táblázatban látható a LIBS módszer összehasonlítása néhány elterjedten használt atomspektroszkópiai módszerrel. 


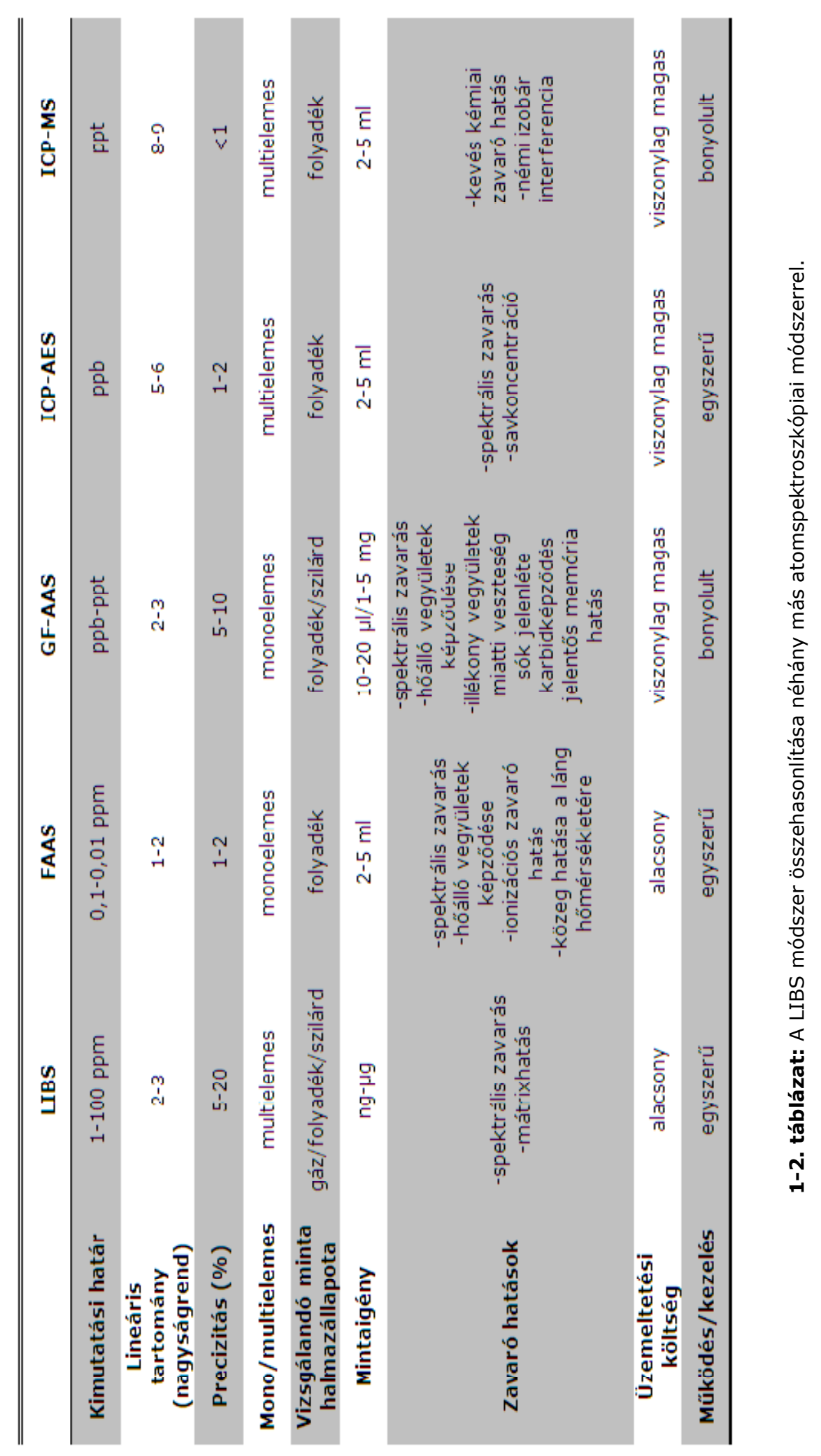




\subsubsection{Zavaró hatások}

Inhomogén szilárd minták esetében a mintaelőkészítés hiánya megnehezítheti az analízist, hiszen a LIBS egy mérés (egy lövés a lézerrel) esetén a mintának csak egy apró részletéről szolgáltat információt (a lézerimpulzus által hátrahagyott kráterek átmérője tipikusan 10-100 $\mu \mathrm{m}$, mélységük pedig legfeljebb néhány $\mu \mathrm{m}$ ). Ezzel szemben az oldott anyagokat tartalmazó gázok és folyadékok homogénnek tekinthetők, és így a mérési térfogatok összetétele az egész mintára nézve reprezentatív.

A LIBS sem mentes a mátrixhatásoktól. Általánosan elfogadott, hogy a minta fizikai tulajdonságai és kémiai összetétele befolyásolja az adott elem által szolgáltatott spektroszkópiai jel nagyságát. Tehát ugyanazon elem, azonos koncentrációban, de különböző mátrixokban különböző intenzitású spektroszkópiai jelet produkál. Mivel a LIBS mérés során mind az ablációt, mind a gerjesztést a lézerimpulzus végzi, így ez a hatás erőteljesebb mint más, mintaelőkészítést igénylő módszerek esetében. A mátrixhatásnak fizikai és kémiai típusait különböztetjük meg.

A fizikai mátrixhatás a minta fizikai tulajdonságaitól függ (fajhő, párolgáshő, hővezetőképesség, fényabszorpció, reflexió, stb) és elsősorban az ablációs lépéssel van kapcsolatban. Más szavakkal, különböző mátrixokban a lézerimpulzus által ablált anyagmennyiség (ablációs ráta) különböző annak ellenére, hogy a lézerimpulzus paraméterei változatlanok. Ez nyilvánvalóan az emissziós spektroszkópiai jel nagyságát is befolyásolja (pl. NIR lézer hullámhosszúságon az üvegminták fényelnyelése csekély, így alig ablálódnak). Az abláció során ráadásul általában elem frakcionálódás is bekövetkezik, vagyis az abláció nem sztöchiometrikus; az ablált anyagban a koncentráció arányok nem egyeznek a mintabeli arányokkal. Például egy olyan fémötvözet esetében, amely alkotóinak forráspontja nagymértékben eltérő, a kisebb forráspontú komponens a plazmában túlreprezentált lesz (pl. bronz mintákban a Zn [89]).

Kémiai mátrixhatásról akkor beszélünk, ha egy vagy több elem jelenléte (vagy a mátrix kémiai összetétele) a mintában befolyásolja a mérendő komponens emissziós jellemzőit. Ez a jelenség is megnehezíti a kalibrációt és így a kvantitatív meghatározást. A kémiai mátrixhatásra példa az ionizációs hatás. Egy elem ionvonalának emiszsziós intenzitása csökken (és a neutrális vonal intenzitása megnő), ha a könnyen ionizálható elemek (pl. alkáliák) koncentrációja szignifikánsan megnő a mátrixban, a plazma elektronkoncentrációjának növekedése miatt. Egy elem azonos koncentrációban, de különböző kémiai formákban ( $\mathrm{pl} . \mathrm{PbNO}_{3}, \mathrm{PbCl}_{2}$, stb.) való jelenléte is eltérő intenzitású spektroszkópiai jelet szolgáltat [32].

Többkomponensű minták esetében szinte mindig számolnunk kell spektrális zavaró hatások fellépésével, vagyis a különböző elemek egymáshoz közel eső vonalainak átlapolódásával. Ennek valószínűségét növeli a Doppler- és Stark effektus, a környező 
gáz nyomása, valamint az atomok és molekulák közötti ütközések által okozott természetes vonalkiszélesedés. Ha a mérések nem vákuumban történnek, a spektrumok kiértékelése még bonyolultabbá válik, hiszen abban megjelennek a környező gáz alkotóelemeinek spektrumvonalai is. A spektrális zavaró hatások mértéke csökkenthető nagyfelbontású spektrométer alkalmazásával.

További zavaró hatásként jelentkezhet a minták víztartalma. Rusak és társai azt tapasztalták, hogy a víztartalom jelentősen csökkenti a LIBS jelintenzitást [90]. Kísérleteik azt mutatták, hogy a két mennyiség között lineáris összefüggés áll fenn. Tehát a víztartalmú mintákat LIBS mérések előtt érdemes szárítani.

A zavaró hatásokról elmondottak miatt a LIBS módszernél - ugyanúgy, mint más szilárdmintás atomspektroszkópiai módszereknél (pl. SS-GFAAS, SS-ETV-ICPAES, LA-ICP-MS, XRF) is - a legjobb analitikai eredmények "mátrixazonos" kalibrációs minták segítségével érhetők el.

A LIBS spektrumok általában jelentős háttérrel rendelkeznek, amely nagymértékben a LIB plazma folytonos emissziójától származik. Ezért a kvantitatív meghatározásokat megelőzően mindenképpen szükséges a spektrumok, vagy legalább a mérővonal intenzitásának háttérkorrekciója. Ez történhet számítógéppel, alkalmas háttérkorrekciós program segítségével [pl. 91] vagy manuálisan, pl. kétpontos háttérkorrekcióval. Kísérleti munkánk során ez utóbbi megközelítést alkamaztuk.

1.3.2.3. Az analitikai teljesítőképesség javítása normalizációs és speciális kalibrációs módszerek alkalmazásával

Jelnormalizációs módszerek

A LIBS analitikai teljesítőképességének növelése az alkalmazások körének kiterjesztésében kulcsfontosságú szerepet játszik, ezért ez a terület folyamatosan kutatott. A terület eddigi eredményei szerint az érzékenység és a lineáris dinamikus tartomány növelésére elsősorban a többszörös lézerimpulzusok alkalmazása javasolt, amely lehetőségekkel a következő fejezetekben foglalkozok. Az analitikai jel precizitásának és pontosságának javítására az egyszeres lézerimpulzusokkal kivitelezett LIBS módszernél is van lehetőség, mégpedig speciális jelnormalizációs és kalibrációs módszerek alkalmazása révén.

A jelnormalizációs eljárások legegyszerübb csoportját azok a módszerek alkotják, amelyek magát az emissziós spektrumot, vagy ennek részleteit használják fel referenciajelként. Az első - az atomemisszión alapuló mérési módszerek során talán leggyakrabban alkalmazott normalizációs technika - a belső standard technika, amely egy referencia spektrumvonal intenzitását tekinti referenciajelnek. A módszert első- 
ként Gerlach alkalmazta [92]. A mérendő elem spektrumvonalának intenzitása helyett analitikai célra ezen vonal és a belső standard elem vonalának intenzitás arányát használta; ez az intenzitások értékeinek ingadozásaitól nagymértékben független. Belső standardként olyan elem használható, amely közel állandó mennyiségben van jelen minden mintában (azt hozzá is adhatjuk a mintáinkhoz). A belső standard kiválasztásánál figyelembe kell venni, hogy gerjesztési potenciálja hasonló legyen a meghatározandó eleméhez és a vonalintenzitás egy nagyságrenden belül hasonló legyen. Ötvözetek mérésekor belső standardként a vas gyakran használatos (pl. [94, 118]).

Egy másik módszer az emissziós spektrum hátterjelét használja referenciajelként. LIBS területen Xu és munkatársai publikáltak először ebben a témában [95]. Eredményeik szerint az egyes lövések által produkált $\mathrm{Zn}$ vagy $\mathrm{Cd}$ jel és a vonalak közelében mért háttérintenzitás korrelációt mutatott. Később több más kutatócsoport (pl. $[96,97])$ is sikeresen alkalmazta a normalizációnak ezt a formáját.

Az emissziós spektrumot felhasználó normalizációs módszerek közé tartozik a spektrális intenzitások integrációjával („teljes integrált emisszió”) való normalizáció is. Elsőként Bolger demonstrálta a módszer alkalmasságát egyenetlen felszínű kőzetek mérése során a lövésről-lövésre fluktuáló jelek korrekcióján keresztül [98]. A normálás sikerességét bizonyította a rézre és vasra meghatározott kalibrációs görbék linearitásának jelentős növekedése. Az eredményesség oka az lehet, amint azt Body és Chadwick [99] később kimutatta, hogy a teljes integrált emisszió és a lézer energiája egymással igen jó arányosságot mutat.

Az ablált anyagmennyiséget (és így a LIBS analitikai jelet) befolyásoló egyik nyilvánvalóan fontos kísérleti körülmény a lézer impulzusenergiája, vagyis végsősoron a teljesítménysűrűség. Az impulzusüzemű lézerek impulzushossza általában igen stabil, azonban az impulzusenergia ingadozása nem ritkán 5-10\% mértékű. Emiatt az ablációs mintabeviteli eljárásoknál gyakran alkalmazott, de a LIBS módszernél érdekes módon ritkán bevált eljárás a lézer impulzusenergiájának lövésről-lövésre való monitorozása egy fotodiódával és az így kapott feszültségjel felhasználása a jelnormalizációra.

Atmoszférikus körülmények között a lézeres ablációt (lézer letörési plazma keltését) éles, csattanó hang kíséri (1.3. fejezet). Chen és Yeung voltak az elsők, akik ezt az akusztikus jelet megpróbálták jelnormalizációra használni [100]. Az oszcilloszkóppal rögzített tranziens akusztikus jel első csúcsa és az általuk monitorozott mangán atomvonal $(403,1 \mathrm{~nm})$ intenzitása között igen jó korrelációt $\left(R^{2}=0,992\right)$ figyeltek meg. A jelenség magyarázatával később Chaléard és társai [33] valamint Možina és munkatársai [101] szolgáltak, amikor megmutatták, hogy az akusztikus jel intenzitásadatai és az ablált anyagmennyiség jó közelítéssel egyenesen arányos egymással. 
Kalibrációs módszerek

Az analitikai kémiában legáltalánosabban alkalmazott kalibrációs módszer a közvetlen/direkt vagy "klasszikus" kalibráció. A szilárdmintás módszerek esetében fellépő mátrixhatás miatt azonban pontos eredmény csak akkor érhető el, ha mátrixazonos standardekkel végezzük el a kalibrációt, amelyek viszont gyakran nehezen beszerezhetők és költségesek.

A szilárd minták analízise során ezért célszerűbb a standard addíciós kalibrációt alkalmazni. A módszer annyiban különleges, hogy nem igényel mátrixazonos standardeket és akár szilárd, akár folyadék halmazállapotú minták esetében lényegében azonos módon, folyadék standarddel kivitelezhető. A módszer kivitelezése során minden egyes ismeretlen mintából egy sorozatot készítünk elő, amelyek egyes tagjaihoz egyre növekvő mennyiségben (pl. $\mu \mathrm{g}, \mu \mathrm{mol}$, stb.) adjuk hozzá a mérendő komponenst. Ezután megmérjük az addíció nélküli, majd a rendre egyre nagyobb addícionált anyagmennyiséget tartalmazó minták jelét. Az addíciót és a mérést ezután újból és újból elvégezzük, az adatokból pedig kalibrációs grafikon szerkeszthető. Az illesztett egyenesnek a vízszintes tengellyel való metszéspontja megadja az ismeretlen mennyiségét a mintaoldatban, amelyet a térfogat ismeretében koncentrációra számíthatunk át. A kivitelezés során természetesen ügyelni kell néhány további gyakorlati részletre. Szilárd minták esetében az addíció térfogat- illetve tömegváltozás nélkül végrehajtható folyadék standard hozzáadásával és az oldószer infralámpával való elpárologtatásával vagy porított minták összekeverésével és pasztillázásával. Az addícionált anyagmennyiségeket úgy célszerű megválasztani, hogy az ne legyen túl kicsi (ekkor az addíció hatása nem jelentkezik a kalibrációs görbén, vagyis a meredekség közel nulla lesz) vagy túl nagy (ekkor pedig az ismeretlen mintabeli mennyiségének a jelre való hatása válik elhanyagolhatóvá, a meredekség túl nagy lesz).

Egy további megközelítés a Tognoni és társai által kidolgozott kalibrációmentes LIBS (CF-LIBS) [24]. Ez a megközelítés lényegében a plazma gerjesztési viszonyainak modellezésen alapul. Kísérleti paraméterként plazmadiagnosztikai adatokat és a minta emissziós spektrumát használja, és a lokális termodinamikai egyensúly (LTE), valamint optikailag vékony plazma (önabszorpció hiánya) feltételezésen alapulva, elméleti úton számítja a minta mennyiségi összetételét. Amint arra több kutatócsoport is rámutatott [102-104], a módszernek nyilvánvaló előnyei mellett számos hátránya is van, legfőképpen az, hogy pontosságát erősen korlátozza az a tény, hogy a plazmadiagnosztikai és spektroszkópiai segédadatok (pl. átmeneti valószínűség adatok) nagyon pontos ismeretét igényli, ezek azonban sokszor csak igen pontatlanul (10-30\% hibával) határozhatók meg.

Egy további, ígéretes kalibrációs eljárás a korrelációs kalibrációs módszer, amely a lineáris korrelációs koefficiens számításán alapul. Mivel ezt az eljárást kutató- 
csoportunk fejlesztette ki [105] és kísérleti munkám során én is alkalmaztam, ezért az alábbiakban annak működését részletesen ismertetem.

A lineáris korrelációs koefficiens széles körben alkalmazott matematikai paraméter, amely egy feltételezett lineáris összefüggés mértékét jellemzi két adatsor között, amelyeket statisztikai értelemben nem lehet egyértelmüen függőnek vagy függetlennek tekinteni. A lineáris korrelációs koefficiens értéke a következő képlettel számítható:

$$
r=\frac{\sum\left(x_{i}-\bar{x}\right)\left(y_{i}-\bar{y}\right)}{\sqrt{\sum\left(x_{i}-\bar{x}\right)^{2}} \sqrt{\sum\left(y_{i}-\bar{y}\right)^{2}}},
$$

ahol $x$ és $y$ a két összehasonlítandó adatsor. Az $r$ értéke -1 és +1 között változhat, nem korreláló adatsorok esetében 0-hoz közelít. Abszolút értékét az adatsorok közötti korreláció jellemzésére használhatjuk; ha $r=+1$, teljes pozitív korrelációról beszélünk, ha $r=-1$, akkor teljes negatív korrelációról van szó.

Ha egy kétkomponensű minta (pl. ötvözet) esetében a korrelációs együtthatót olyan spektrumok párban való összehasonlításakor számítjuk ki, amikor az egyik spektrum állandó, mégpedig pl. egy ötvözet egyik komponense tiszta állapotban (pl. $\mathrm{X}$ ), a másik pedig a két komponenst változó arányban tartalmazó ötvözetminták sorozata (Y), akkor az $r$ értékének az összetétel függvényében való ábrázolása egy monoton növekvő, egyértékű, korlátos függvényt ad eredményül, ami matematikailag alkalmas kalibrációs célra. Az így kapott kalibrációs görbék ( $r$ a koncentráció arány függvényében) legalább két okból is értékesek lehetnek az analitikai alkalmazások során. Az első ok az, hogy $r$ érzéketlen bármelyik, sőt akár mindkét összehasonlított spektrum lineáris transzformációjára. Ez azt jelenti, hogy a kapott kalibrációs görbe alakja és helyzete független a detektor érzékenységétől és az alapvonal eltolódásától mindaddig, amíg ezek a hatások a spektrum egészére nézve ugyanúgy jelentkeznek. Ezek a kalibrációs görbék tehát eltárolhatók és hosszú ideig használhatók egy bizonyos kísérleti beállításnál. A második ok, hogy a lineáris korrelációs koefficiens robusztus jellemző, így értéke kevésbé ingadozik (szór), mint az összehasonlított spektrumokban az egyes vonalak intenzitásai - vagyis alkalmazása jelentősen javítja a precizitást.

Az adatkiértékelés során javasolható a spektrumok „maszkolása”. A maszkolásnál pontról pontra megszorozzuk a spektrumot egy azonos hosszúságú adatvektorral, amely nullákat és egyeseket tartalmaz. Az egyesek azokat a helyeket jelölik, ahol a spektrális információt meg kívánjuk tartani, pl. a mérendő komponensek zavarmentes, intenzív vonalainak helye. Így lehetségessé válik az olyan spektrumrészletek figyelmen kívül hagyása, amelyek dominánsak, de analitikai szempontból haszontala- 
nok és/vagy spektrális zavarással érintettek. Megemlíthető, hogy egy spektrumrészlet kivágása is valószínűleg hasonló eredménnyel alkalmazható.

A kalibrációs görbe felvételéhez egy ismert összetételű kétkomponensü mintasorozatot alkalmazunk. A kiszámított korrelációs kalibrációs görbéről, ami a tapasztalatok szerint egy harmadfokú polinommal jól illeszthető, ezek után az ismeretlen minta korrelációs együtthatója alapján az összetétel visszaolvasható.

A módszer alkalmazása többkomponensű mintákra is kiterjeszthető, mégpedig oly módon, hogy lényegében kételemes maszkok sorozatát alkalmazzuk a mért spektrumokra. Szükséges, hogy minden szignifikáns mintakomponenssel $(N)$ számoljunk, de csak $N$ - 1 elempár kombinációjára van szükség, amelyeknek minden elemet legalább egyszer tartalmazniuk kell. Annak előzetes ellenőrzése, hogy egy ismeretlen mintában milyen elemek fordulnak elő, a LIBS módszerrel könnyen elvégezhető. Külön-külön való kalibráció útján a páronkénti koncentráció arányok (pl. $c_{1,2}$ az 1-es és 2-es elemre, és így tovább a kiválasztott $N$-1 kombinációra) meghatározhatók. Ezek ismeretében és azt feltételezve, hogy teljeskörü az elemzés, a felírható $N$ számú egyenletből a koncentrációk meghatározhatók:

$$
\begin{gathered}
\sum_{\mathrm{m}=2}^{\mathrm{N}} \mathrm{c}_{\mathrm{m}-1, \mathrm{~m}}=1 \\
c_{1} /\left(c_{1}+c_{2}\right)=c_{1,2} \\
c_{2} /\left(c_{2}+c_{3}\right)=c_{2,3} \\
\cdot \\
c_{N-1} /\left(c_{N-1}+c_{N}\right)=c_{N-1, N}
\end{gathered}
$$

Ezeknek az egyenleteknek a megoldásával megkapjuk az ismeretlen mintában lévő elemek koncentrációját. Meg kell említeni, hogy a leírt multielemes alkalmazás hátránya, hogy a meghatározott koncentrációk ( $c_{1}$-től $c_{N}$-ig) akkumulálják az egyedi koncentrációarányok hibáit ( $c_{i, j}$ értékei).

Többféle mintatípus ( $p l$. sárgaréz ötvözetek, alumínium ötvözetek, tablettázott alumínium/vas porkeverékek) esetében is sikerült a módszer jó teljesítőképességét bemutatni. A korrelációs kalibrációval kapott eredmények mindig pontosabbak és jobb precizitásúak voltak, mint a klasszikus kalibrációval nyerhetőek.

Később a módszer továbbfejlesztésére is sor került [106]. Ezen javítások célja az volt, hogy az általános spektroszkópiai és nyomanalitikai alkalmazást is lehetővé tegyék. Bevezették egy, a mérendővel nagyságrendileg összemérhető koncentrációjú belső referencia komponens mintához való hozzáadását (R). Ez nemcsak a nyomanali- 
tikai alkalmazást könnyíti meg, hanem az ismeretlen abszolút koncentrációi is könynyen, közvetlenül kiszámíthatók az $\mathrm{R}$ ismert abszolút koncentrációja alapján. A másik javasolt változtatás, hogy a kalibrációs grafikon abszcisszáján az $[R] /([X]+[R])$ arány helyett az $[X] /[R]$ arány van feltüntetve. A legfőbb érv emellett a változtatás mellett az, hogy egy általános, többkomponensü minta esetében nem lehet közvetlenül használni az $[R] /([X]+[R])$ kifejezést attól kezdve, hogy ennek az értéke nem szolgáltat közvetlen százalékarányos eredményt az összetételre, ahogy ez a kétkomponensü minták esetében volt. $[\mathrm{X}] /[\mathrm{R}]$ képes lefedni a relatív koncentrációtartomány legalább 3 nagyságrendjét és ily módon könnyebb kiszámolni az abszolút mintakoncentrációt az $[X] /[R]$ arányból, amely az ismert $[R]$ értéken alapul. Ezt a továbbfejlesztett változatot általánosított lineáris korrelációs módszernek (GLCM) nevezték el és általános alkalmazhatóságát egy UV-VIS spektrofotometriás és két induktív csatolású plazma tömegspektrometriás (ICP-MS) alkalmazáson keresztül mutatták be. 


\subsection{Kétimpulzusos lézer indukált plazma spektroszkópia (DP-LIBS)}

A LIBS számos előnyös tulajdonsága mellett vannak természetesen olyan teljesítményjellemzői, melyek fejlesztést igényelnek. Az elérhető kimutatási határok még a legkönnyebben mérhető elemekre is a ppm tartományba esnek, amely értékek nem kelhetnek versenyre a rutinszerüen használt atomspektroszkópiai módszerek többsége által elérhető adatokkal. Emellett az ismételhetőség a legjobb esetben csak 5-10\% körül van, amelynek lehetséges okai a lézer instabilitása, a detektorzaj, az ablációs ráta és a plazma paramétereinek változása, valamint a minták mikroszkópikus inhomogenitása. A LOD és a precizitás javítására 1969-ben Piepmeier és Malmstadt [107], majd 1970-ben Scott és Strasheim [14] javasolták először a két lézerimpulzus alkalmazását. A DP-LIBS elrendezésben a két lézerimpulzus követési ideje rövidebb az első impulzus által létrehozott plazma élettartamánál. Az 1-13. ábrán láthatóak egy DPLIBS mérés fontosabb időszakaszai.

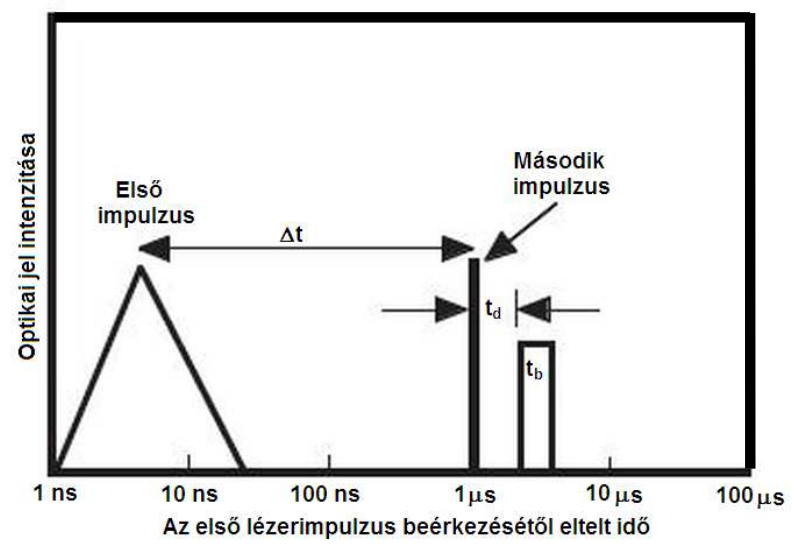

1-13. ábra: A DP-LIBS fontosabb időbeli szakaszai ( $\Delta \mathrm{t}$ : impulzusok követési ideje; $\mathrm{t}_{\mathrm{d}}$ (késleltetési idő): a plazma létrejötte és az adatgyüjtés megkezdése között eltelt idő;

$t_{b}$ (integrációs idő): az adatgyűjtés időtartama) [45].

A javaslatot azzal indokolták, hogy mivel a lézer energiájának egy része abszorbeálódik a plazmában, egy második impulzus beérkezése tovább gerjeszthetné a plazmában jelenlévő specieszeket. A javasolt technikát több-kevesebb sikerrel demonstrálták is, azonban reprodukálható impulzussorozatok előállítása a módszerhez szükséges időskálán az akkor elérhető lézerekkel nagyon nehéz volt, ezért arra a következtetésre jutottak, hogy kvantitatív analízisekhez mégis az SP-LIBS az előnyösebb. 1984-ben Cremers és társai is kipróbálták a DP-LIBS megközelítést és jelentős javulást értek el a bór vízben való meghatározásánál (SP: $L O D=1200 \mu \mathrm{g} / \mathrm{ml}$; DP: $L O D=80 \mu \mathrm{g} / \mathrm{ml}$ ) [82]. 
Az egyértelmü siker ellenére ez maradt az egyetlen DP-LIBS alkalmazás egészen a következő évtizedig. Ekkor jelent meg Übbing-nek és munkatársainak a DP-LIBS területen készült tanulmánya, amelyben arról számoltak be, hogy a második lézerimpulzusnak csak egy kis része nyelődik el az első impulzus által létrehozott plazmában, ennek ellenére a második impulzus hatására jelentős mértékben megnő a plazmahőmérséklet. Az emissziós vonalak intenzitásában is nagymértékű növekedést figyeltek meg [108]. Ezután több csoport is elkezdett foglalkozni a DP-LIBS módszerrel, de igazából csak a legutóbbi évtizedben (kb. 2000 óta) nőtt meg jelentősen a közlemények száma ebben a témában. A tapasztalatok egységesen azt mutatták, hogy két lézerimpulzus alkalmazásával a módszer teljesítőképességében jelentős növekedés érhető el. Az 1-14. ábrán egyértelműen látszik a DP-LIBS egyik nagy előnye, a spektrumvonalak intenzitásának jelentős növekedése. Ezen felül több tanulmányban is a szórás és a LOD csökkenését dokumentálták a kutatók az SP-LIBS-hez képest [57, 109-114], valamint azt is megfigyelték, hogy a DP-LIBS kalibrációs görbék dinamikus tartománya kiszélesedik (pl. [187]). Ez utóbbi oka valószínűleg a második lézerimpulzus által létrehozott lökéshullámfront mögötti nyomáscsökkenés következtében kialakuló kisebb részecske sürüség.

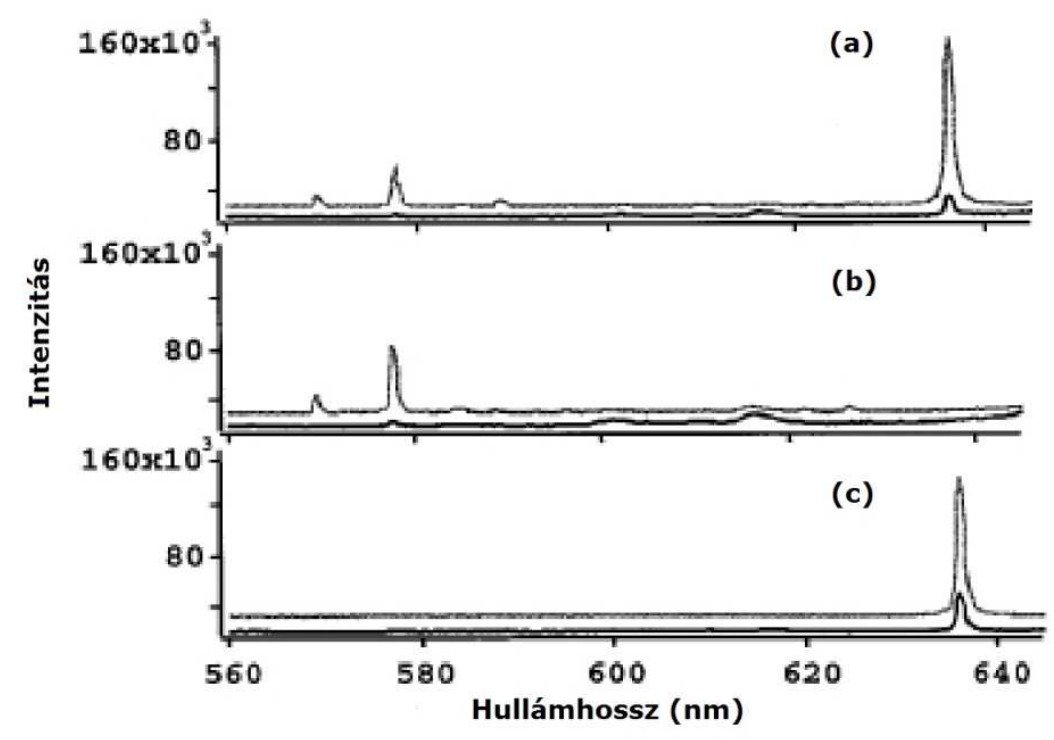

1-14. ábra: SP-LIBS (alsó görbe) és DP-LIBS (felső görbe) spektrumok összehasonlítása (a) bronz, (b) réz és (c) cink mintára [120].

Ma elmondható, hogy a DP-LIBS módszer technikai kivitelezésének már kialakult optikai módozatai vannak. A két lézerimpulzussal történő gerjesztés egyrészt megoldható két lézer működésének időbeli szinkronizálásával, másrészt egy lézer alkalmazásával, amely képes reprodukálható impulzussorozatokat kibocsátani, harmadrészt pedig szintén egy lézerrel, amely által kibocsátott impulzust nyalábosztóval két részre 
osztják és optikailag oldják meg a késleltetést. A DP-LIBS megvalósításának lehetőségeit szemlélteti az 1-15. ábra.
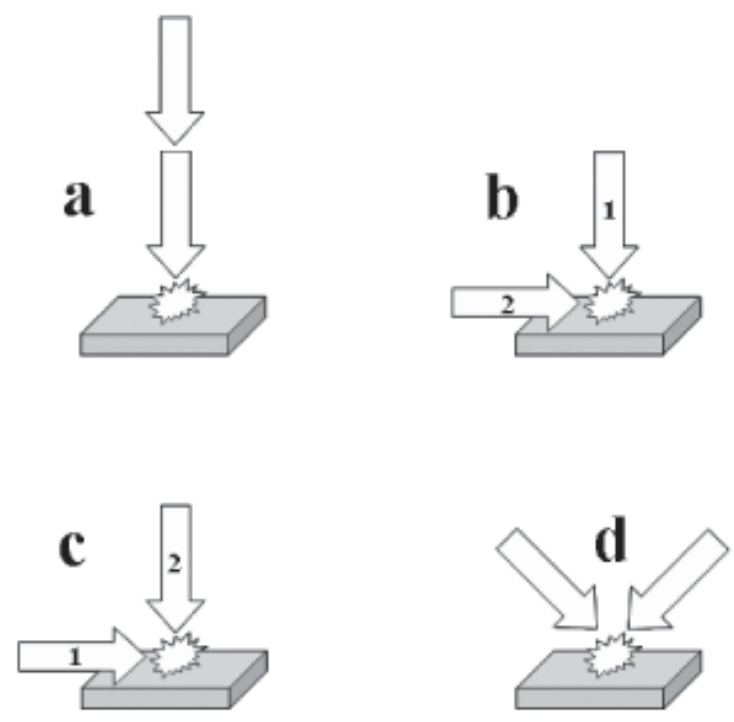

1-15. ábra: A különböző DP-LIBS konfigurációk: (a) kolineáris,

(b) ortogonális újrahevítéses, (c) ortogonális előablációs,

(d) keresztirányú (a nyilak a gerjesztő lézerimpulzusok irányát, a számok a sorrendjüket reprezentálják) [2].

Az (a) a kolineáris elrendezés, amelyben mindkét lézerimpulzus ugyanabból, általában a mintára merőleges irányból érkezik. A (b) az ortogonális újrahevítéses módszer, amikor az első impulzus a mintára merőleges irányból érkezik, létrehozza a mikroplazmát, majd a második impulzus, amely a mintával párhuzamos irányban érkezik, kölcsönhat az első impulzus által létrehozott plazmával. A (c) az ortogonális előablációs konfiguráció, amelyben az első impulzus érkezik a mintával párhuzamos irányból, közel a mintafelszínhez, felmelegíti azt és a környezetét, majd ekkor érkezik a második impulzus merőleges irányból a mintára és létrehozza a plazmát. $A$ (d) keresztirányú megoldás viszonylag ritka. Nagy előnye, hogy a fénygyűjtő optika elhelyezésére viszonylag optimális pozíciót (a minta felett, a két lézernyaláb között) kínál.

A legelterjedtebb a kolineáris elrendezés, mivel ez a legegyszerűbb és akár egy lézerrel is megvalósítható. Természetesen mindegyik elrendezésnél rendkívül fontos a lézerimpulzusok nagyon pontos térbeli és időbeli pozícionálása, hiszen a két impulzusnak pontosan ugyanarra a helyre kell érkeznie és lényeges, hogy megfelelő legyen az impulzusok közötti késleltetési idő is. A szakirodalomban különböző véleményeket találhatunk arra vonatkozólag, hogy mekkora az optimális késleltetési idő. Ez természetesen attól is függ, hogy milyen paraméter (kráter mélysége vagy térfogata, ionho- 
zam, ionok kinetikus energiája, emissziós intenzitás, plazmahőmérséklet, elektronsűrűség, ablációs ráta, stb) optimálása a cél. Ennek megfelelően az optimális késleltetési idő ps-tól egészen néhány száz $\mu$ s-ig változhat.

Koudoumas és társai demonstrálták, hogy az 1 pikoszekundumnál nagyobb késleltetési idővel érkező második impulzus hatására Si minta esetében az ionhozam növekedett és a késleltetési idő növelésével az ionok kinetikus energiája is nagyobb lett [115]. Ez a hatás néhány ps-tól néhány tíz ps-ig volt megfigyelhető. Forsman és csoportja azt tapasztalták, hogy ha az impulzusokat néhány tíz ns választja el egymástól, az ablált anyag mennyisége 3-10-szeresére növekszik [116]. Az alkalmazott minták rozsdamentes acél, Al és Si voltak, a lézerimpulzusok hossza pedig 3 ns. Mao és munkatársai a késleltetési idő hatását vizsgálták a plazma hőmérsékletére, részecskesűrűségére, az emissziós intenzitásra és a krátertérfogatra az 1 ns - $10 \mu$ s tartományban [117]. Azt tapasztalták, hogy 100-200 ns között az elektronsürüség és a hőmérséklet drasztikusan változást mutat. Az intenzitás kis mértékben csökken, amint az idő 100 ns-ra növekszik, majd 100 és 200 ns között kb. kétszeresére növekszik. A kráterek mélysége és térfogata szintén jelentősen növekszik 200 ns-nál hosszabb késleltetési idők alkalmazásával is.

Nem teljesen tisztázott azonban, hogy mi az oka az analitikai teljesítőképesség (intenzitás növekedés, RSD és LOD csökkenés) nagymértékű javulásának a két impulzussal történő gerjesztés során. Ami biztos, hogy a magyarázat nem csak a nagyobb teljes impulzusenergiában rejlik, mivel több kutatócsoport annak ellenére is jelnövekedésről számolt be, hogy kísérleteik során a két impulzus összenergiája megegyezett az egy impulzus energiájával [118, 119]. A szakirodalom egyelöre csak abban ért egyet, hogy a jobb teljesítőképesség több, valószínűleg igen komplex folyamat eredménye. A folyamatok tanulmányozása szempontjából az ortogonális elrendezések előnyösebbek, mert ezekben a konfigurációkban az egyik nyaláb nem hoz létre ablációt, így a folyamatok egyszerübbek.

Piepmeier és Malmstadt [107], valamint Scott és Strasheim [14] is úgy gondolták, hogy a második impulzus egy része elnyelődik a plazmában és így újrahevíti azt. Az első lézerimpulzus beérkezése után a mintából kiszakadó cseppek és szilárd mintadarabok a forró plazmába jutnak, ahol további párolgás és ionizáció következik be. Az első impulzus utáni atomizációs és lehűlési folyamatokat követően a plazmában relatíve magas a semleges atomok és a gyökök koncentrációja, a hőmérséklet alacsony és az emissziós vonalak intenzitása gyenge. Az emisszió csökkenése kb. $10000 \mathrm{~K}$ hőmérséklet környékén kezdődik. A fő gerjesztési folyamatok az elektronütközéses gerjesztési reakciók, amelyek aránya nagyon gyorsan csökken a hőmérséklet csökkenésével, mivel az elektronsürüség erősen függ a hőmérséklettől. Így szerintük a második impulzus fő hatása a plazma újrahevítése. 
Angel és társai (2001) ortogonális előablációs elrendezésben, ns impulzushosszú lézerek segítségével tanulmányozták a DP-LIB plazmákat. Jelentős jelnövekedést figyeltek meg az egyimpulzusos esethez képest, továbbá azt tapasztalták, hogy a jelnövekedés mértéke mátrixfüggő. Az SP- és DP-LIB plazmákról készített felvételek igazolták, hogy az intenzitásnövekedés a DP-LIB plazma nagyobb méretének eredménye, a megnövekedett abláció pedig feltehetően a minta és az ablációs impulzus közötti hatékonyabb csatolás következtében alakul ki. A szerzők szerint a DP-LIBS módszerrel elérhető javulásokért felelős fő mechanizmusok feltehetően a lézerenergia plazma általi abszorpciója és a plazma nagyobb mérete [120].

Colao és munkatársai (2002) kolineáris elrendésben, ns impulzushosszú lézerrel vizsgálták a nitrogén vonalak intenzitásának változását. A második impulzust követően, minden tanulmányozott impulzuskövetési idő esetében a vonalak szignifikáns csökkenését tapasztalták [58], amelyre a következő magyarázatot javasolták: az első impulzus csökkenti a levegő mennyiségét a mintafelszín közelében, ennek következtében csökken a nitrogén koncentrációja is.

Noll és társai (2004) szintén kolineáris elrendezést és ns impulzushosszú lézerfényt használtak kísérleteik során. Hasonlóképpen arra jutottak, hogy a teljesítményjellemzők javulásának elsődleges oka a részecskesűrűség csökkenése a minta környezetében az első lézerimpulzust követően [121]. A második impulzus mintával való kölcsönhatása így hatékonyabb. Plazmaújrahevítést nem figyeltek meg. A második impulzus hatására a plazma kiterjedése gyorsabb volt az első impulzus hatására létrejött csökkent sürüségü atmoszférába. Mindezek eredményeképpen egy lényegesen nagyobb térfogatú plazma keletkezett. Az elektronsürüség hasonló volt az egy- és kétimpulzusos esetekben, azonos energiák mellett. A második impulzus hatására létrejött nagyobb plazma térfogat és a megnövekedett ablált mintamennyiség következtében az elemek emissziója sokkal intenzívebb és hosszabb élettartamú volt.

Koudoumas és munkatársai (2004) ugyancsak kolineáris elrendezésben, fs és ps impulzushosszú lézerekkel, Si minta esetében azt tapasztalták, hogy a második impulzus hatására megnőtt az ionhozam és a szilícium ionok kinetikus energiája [115]. Úgy gondolták, hogy a tapasztalt jelnövekedés egy megváltozott optikai tulajdonságokkal rendelkező olvadt réteg kialakulásának az eredménye. A második impulzus ionhozamra gyakorolt hatása nem magyarázható gázfázisbeli kölcsönhatásokkal, mivel az impulzusok közötti késleltetési idő (ps nagyságrend) túl rövid a gázfázis jelentős kiterjedéséhez. 1 ps-nál rövidebb impulzuskövetési idő esetén nem képződött olvadt zóna, és a hatás hasonló volt az egyimpulzusos esethez. Nagyobb impulzuskövetési időknél az olvadékréteg vastagsága összehasonlíthatóvá vált a penetrációs mélységgel, így a második impulzus alkalmazása az ionhozam és a kinetikus energia növekedéséhez vezetett. 
Gautier és munkatársai (2005) az ortogonális elrendezésü, ns-os impulzusokkal dolgozó DP-LIBS hatékonyságát befolyásoló paraméterek részletes vizsgálatát végezték el [119]. Munkájuk célja az újrahevítéses és az előablációs elrendezések összehasonlítása volt. Az optimális emissziós intenzitást 200 ns-os impulzuskövetési időnél tapasztalták az előablációs ortogonális konfigurációban. Rámutattak, hogy az emisszió növekedése összefüggésben van a második impulzus energiájának plazma általi abszorpciójával. Arra a következtetésre jutottak, hogy a gerjesztési energiák és az intenzitásnövekedés között tapasztalt korrelációnak valószínűleg a plazmahőmérséklet növekedése az elsődleges oka. Úgy találták, hogy az intenzitásnövekedés összefüggésben van a plazma sűrüségében bekövetkező változással az előablációs impulzust követően. A gerjesztési energiák és az intenzitásnövekedés közötti korrelációt az előablációs elrendezésben is megfigyelték. A szerzők végül arra a következtetésre jutottak, hogy a LIBS érzékenységének növelése céljából az ortogonális újrahevítéses konfiguráció az előnyösebb.

Forsman és társai (2005) egy négylépéses modellt ajánlottak a kolineáris elrendezésüknél tapasztalt megnövekedett abláció leírására [116]. Az első impulzus által létrehozott plazma elnyeli a második impulzus energiáját és ez a magas hőmérsékletű plazma hatással van a mintafelületre. Az első impulzus ideje alatt az abláció mérsékelt a plazmaképződés során fejlődő nyomás miatt. A második impulzus azáltal, hogy a plazmát hevíti, hőforrásként szolgál. Ezáltal az abláció hatékonyabbá válik.

Összefoglalóan tehát a szakirodalomban alapvetően három lehetséges magyarázattal találkozhatunk, hogy vajon milyen folyamat(ok) okozzák a DP-LIBS-ben a jelnövekedést:

(1) a második lézerimpulzus egy része elnyelődik az első impulzus által létrehozott plazmában, így hatékonyabb gerjesztést tesz lehetővé, következésképpen nagyobb lesz a plazma elektronsürüsége és hőmérséklete;

(2) nagyobb ablált anyagmennyiség az által, hogy az első impulzus által létrehozott plazma felmelegíti a mintafelszínt;

(3) az első plazma keletkezésével kapcsolatos fizikai és energetikai hatások, úgymint lecsökkent nyomás és számsűrűség az első plazma képződésének a helyén és magasabb mintahőmérséklet a második impulzus hatására. Ez alacsonyabb ablációs és/vagy plazma küszöbenergiához vezet, több anyag ablálódik és nő a plazma hőmérséklete is.

A teljesíményjellemzőkben bekövetkező javulásnak köszönhetően a DP-LIBS egyre szélesebb körben alkalmazott. Ezt mutatja, hogy megjelentek az első kereskedelmi forgalomban kapható műszerek (pl. Modi, Crossfire) és az utóbbi években meg- 
jelent LIBS vonatkozású szakkönyvek $[6,45,93]$ is egyre többet foglalkoznak a témával. Az első DP-LIBS "review" cikkek is megjelentek (pl. [122, 123]). 


\subsection{Többimpulzusos lézer indukált plazma spektroszkópia (MP-LIBS)}

A két lézerimpulzus alkalmazásával elért javulások láttán természetesen felmerült néhány kutatóban a kérdés, hogy vajon három vagy több impulzus használatával még tovább javíthatók-e a LIBS analitikai teljesítményjellemzői. A szakirodalomban fellelhető, MP-LIBS kérdéskörével foglalkozó cikkek - amelyek száma igen csekély (tucatnál kevesebb) - eredményei alapján a válasz igen. Az MP-LIBS tanulmányok egy része alkalmazás jellegü, míg a többi a teljesítményjellemzők javulásának okait kutatja, kisebb-nagyobb részletességgel. Ebben a fejezetben ezen cikkek több impulzusra vonatkozó eredményeit tekintem át.

A több lézerimpulzussal történő gerjesztés praktikusan csak kolineáris módban valósítható meg egyetlen, olyan lézer fényforrás alkalmazásával, amely képes többszörös lézerimpulzusok kibocsátására. A szakirodalomban az MP-LIBS berendezések három különböző osztályával találkozhatunk, amelyek elsődlegesen a spektrális adatgyűjtés és az impulzusok szinkronizációjában különböznek. A Noll kutatócsoport - akik a kevés MP-LIBS cikk jelentős részét publikálták - kísérleti berendezéseiben a lézerimpulzusok száma szabályozható, az adatgyűjtés pedig az utolsó lézerimpulzus beérkezése után bizonyos késleltetési idővel kezdődik és az integrációs idő $\mu$ s nagyságrendű [94, 118, 124, 125]. Az MP-LIBS berendezések másik osztályát képviselik a kHz-es ismétlési sebességű, kontrollálatlan hosszúságú impulzussorozatokat kibocsátó microchip lézereket és nem kapuzott spektrométereket tartalmazó berendezések [31, 126-128]. Végül a harmadik típus, amelybe kutatócsoportunk berendezése is tartozik, szabályozható impulzusszámú lézert tartalmaz, integrációs ideje ms nagyságrendű és az adatgyűjtés az első impulzus beérkezése után indul bizonyos késletetési idővel [35, $37,129,130]$.

Noll és társai 1995-ben megjelent közleményükben összehasonlították az egy, kettő és négy impulzus által ablált anyagmennyiséget [118]. Kísérleteikben egy impulzusüzemü, Q-kapcsolós Nd:YAG lézert használtak, amely által kibocsátott lézerimpulzusok száma 1 és 6 között volt szabályozható, valamint az impulzusenergiák és a követési idők kontrollálhatók voltak. Az impulzuskövetési idő minden esetben 6 s volt. Méréseikhez $100 \mu \mathrm{m}$ vastagságú rozsdamentes acélfóliát használtak és különböző energiák mellett meghatározták azt a lövésszámot, amely a fólia átlyukasztásához volt szükséges. Ez a lövésszám nagyjából fordított arányosságot mutat a lövésenkénti ablált anyag mennyiségével. Azt tapasztalták, hogy 1013 mbar nyomáson az egy impulzussal ablált anyag mennyisége nem növekedett a lövések energiájának növelésével. Hasonló eredményre jutott 1971-ben Piepmeier és Osten is, akik szerint ez a minta felett képződött plazma árnyékolásának köszönhető [131]. A két impulzussal ablált anyag mennyisége nagyobb volt, mint egy impulzussal ugyanannál az energiánál, és 
négy impulzus alkalmazásával még tovább nőtt.

A csoport 2000-ben megjelent cikkében acélminták többszörös lézerimpulzusokkal történt multielemes analízisét mutatja be [94]. A kísérleteikhez használt Qkapcsolós Nd:YAG lézer három impulzus kibocsátására volt alkalmas, amely impulzusok energiája azonos, hosszuk pedig kb. 16 ns volt. Az impulzuskövetési idő 25 s volt az első és a második, valamint $40 \mu \mathrm{s}$ a második és a harmadik impulzus között. A lövés energiája $300 \mathrm{~mJ}$ volt. Az impulzusszám függvényében megvizsgálták a szén 193,09 nm-es vonalának intenzitását az idő függvényében. Egy lézerimpulzus alkalmazásánál azt tapasztalták, hogy a jel kevesebb, mint 10 ns alatt nagyon meredeken fut fel, majd a maximum elérése után kb. 500 ns alatt lecseng. Ebben a lecsengő szakaszban minimális különbséget észleltek különböző minták esetében. Két impulzus használatánál a jel viselkedése eltérő. Míg az emelkedő szakasz két minta esetében összehasonlítható, addig a lecsengő jelentősen különbözik. Továbbá a jel jóval nagyobb, összehasonlítva az egyimpulzusos esettel. A harmadik lézerimpulzus után a jel ugyanakkora, mint a második után. A különböző elemek, koncentrációk és kísérleti körülmények (pl. lézerenergia, impulzusok követési ideje, fókuszálás) során kapott jelek megegyeztek a fent leírtakkal mindamellett, hogy a lecsengés időtartama és így az integráció ideje és optimális pozíciója függött ezen paraméterektől. A legjobb kimutatási határokat 650 ns késleltetési idő és 12 s integrációs idő mellett érték el.

2004-es tanulmányukban felületi reve réteggel rendelkező acélminták tömbfázisban történt analíziséről számoltak be [132]. Az iparban az ilyen típusú mintákat általában SD-OES vagy XRF módszerrel vizsgálják be, azonban a mérések előtt a felületi reve réteget csiszolással vagy maratással el kell távolítani. A szerzők úgy gondolták, hogy a LIBS lehetőséget nyújt mindkét lépés (mintaelőkészítés és analízis) elvégzésére. A kísérletekhez preparált minták egyik oldalát megcsiszolták, míg a másik oldalon meghagyták az eredeti reve réteget. Mindkét oldalt megmérték LIBS módszerrel és összehasonlítás céljából a csiszolt oldalt SD-OES módszerrel is. Első lépésben megvizsgálták az ablációs ráta változását az impulzusszám függvényében, egy (SP), kettő (DP) és három (TP) lézerimpulzus alkalmazásával, konstans értéken tartva az impulzusok energiáját $(600 \mathrm{~J})$ és az összimpulzusszámot ( $\mathrm{SP}=3000$, $\mathrm{DP}=1500$ és $\mathrm{TP}=1000$ ). A három impulzussal létrehozott kráterek átlagos mélysége 0,27 mm-nek adódott, amely érték 2,7-szer nagyobb volt az egyimpulzusos krátermélységnél és 1,4-szer nagyobb a kétimpulzusosnál. A kráterek átmérője nem mutatott szignifikáns változást. A minták mindkét oldalán elvégezték a kalibrációt annak érdekében, hogy megvizsgálják a mintaelőkészítés során képződött kráter geometriájának esetleges hatását: (1) a csiszolt oldalon $D P=100$ előkészítő lövés és $D P=500$ mérésre felhasznált lövés, míg (2) a felületi reve réteget tartalmazó oldalon TP=1000 mintaelőkészítő lövés, $D P=100$ előkészítő lövés és $D P=500$ mérésre felhasznált lövés segítségével. Az 
eredmények összehasonlítása után azt tapasztalták, hogy a kalibráció precizitása és érzékenysége kis mértékben ugyan, de rosszabb volt a reve réteget tartalmazó oldaIon, ahol szükséges volt a mintaelőkészítő lépés. A kimutatási határok a vizsgált elemekre (9) kettő kivételével $10 \mu \mathrm{g} / \mathrm{g}$ érték alattiak voltak az (1) esetben, míg a (2) esetben néhány elemnél a többszörösére emelkedtek.

Kísérleti munkám kezdetét megelőzően kutatócsoportunknak egy MP-LIBS vonatkozású közleménye jelent meg 2005-ben, amelyben a teljesítményjellemzők javulásának mértékét tanulmányozták többszörös lézerimpulzusok alkalmazása esetén [35]. Az 1-16. ábra cink minta kettő és négy impulzussal felvett spektrumát ábrázolja. Látható, ha kettő helyett négyre emelték az impulzusszámot, az emissziós jel igen nagymértékü növekedést mutatott, míg a folytonos háttéremisszió változása elhanyagolható volt. Megvizsgálták az impulzusszámmal normalizált jel viselkedését is az impulzusszám függvényében, 1-7 impulzus alkalmazásával és azt tapasztalták, hogy a normalizált jel is mutat növekedést az impulzusok számának növelésével.

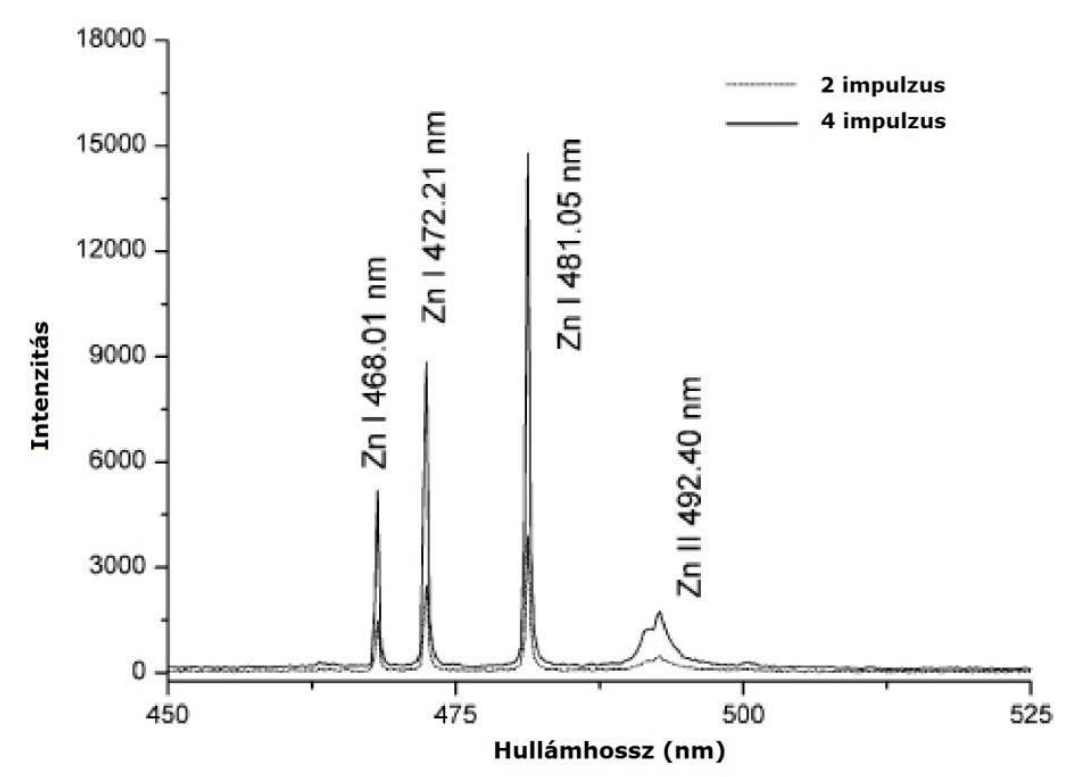

1-16. ábra: Cink minta két- és négyimpulzusos spektrumának részlete [35].

7 impulzus alkalmazásával 4-6-szoros javulást értek el az ismételhetőségben az egyimpulzusos esethez képest, azaz a relatív standard deviáció 2-5\%-ra csökkent csupán 5 párhuzamos mérés elvégzésével, amely igazán kiemelkedő eredmény LIBS területen, de bármely más szilárdmintás analitikai módszernél is nagyon jónak számít.

A Noll csoport 2006-ban kifejlesztett egy többimpulzusos LIBS módszert acélminták bevonatvastagságának és mélységi profilozásának mozgó szalagon való meghatározására: más szóval a LIBS olyan szituációban való alkalmazására, ahol csak 
egyetlen lézerlövésre van lehetőség minden egyes acéllemez pozícióban [133]. A mélységi eloszlás meghatározását a következőképpen közelítették meg: kis léptékekben változtatták a lövés energiáját és vizsgálták a keletkezett kráterek mélységét, valamint minden lövés után rögzítették a LIBS jelet. Eredményeik demonstrálták a LIBS alkalmasságát galvanizált bevonatok alumínium tartalmának online mélységi eloszlásvizsgálatára, valamint az elérhető mélységi információ három nagyságrenddel nőtt, ha három impulzussal dolgoztak és minden egyes impulzus után mérték a LIBS jelet.

Szintén 2006-os tanulmányukban a többszörös lézerimpulzusokkal létrehozott ablációt vizsgálták az impulzuskövetési idők és a környező, konstans nyomású gáz minőségének függvényében [124]. Különböző gázokat és gázkeverékeket alkalmaztak, amelyek argonból, oxigénből és nitrogénből tevődtek össze. Meghatározták egy acéllemez átütéséhez szükséges lövésszámokat az előbbi paraméterek változtatásával. A szerzők munkája azt mutatja, hogy az abláció során nem a gáz minőségi összetétele, hanem a sürüsége dominál és az oxigéntartalom szerepe csekély a tanulmányozott gázkeverékek esetében. Közel lineáris összefüggést állapítottak meg a gázsűrüség és a lövésszám között. A gáz sűrűségének növelésével a lövésszám egyaránt csökkent SP és DP esetében. Minden impulzuskövetési idő esetében az impulzusszám növelésével jelentősen nőtt a lövés behatolási mélysége.

2007-ben Noll és társai a többszörös lézerimpulzusokkal indukált plazmák diagnosztikáját és az abláció tanulmányozását végezték el [125]. Kísérleteik során a fent bemutatott eredményekhez hasonlóan azt tapasztalták, hogy az impulzusszám növelésének hatására nőtt az ablált anyagmennyiség. A plazmafelvételekről megállapítható volt, hogy az SP-LIB plazma mindvégig a mintafelszín közelében tartózkodik és hül le, míg az MP-LIB plazmák eltávolodnak. Továbbá azt is megállapították, hogy az MP-LIB plazmák térfogata jóval nagyobb és az emisszió élettartama hosszabb. Az SP plazma sűrűsége az impulzust követő néhány száz ns során nagyobb volt. Ugyanezen idő alatt az atomvonalak alapján meghatározott elektron hőmérséklet alacsonyabb volt, mint az MP-LIB plazmáké, míg az ionvonalak alapján számított elektron hőmérséklet mindig nagyobbnak adódott az SP-LIB plazmákra. A kutatócsoport 2008-ban az SP- és MP-LIB plazmák összehasonlításával kapcsolatban újból, az előbb bemutatott eredményekkel analóg tapasztalatokat szerzett [134].

Összefoglalóan tehát elmondható, hogy az MP-LIBS-ben lejátszódó folyamatok még összetettebbek, mint a DP-LIBS-ben. A spektrális effektusok viszonylag jól dokumentáltak és már több, sikeres alkalmazás is született, azonban a plazmákban és a mintafelületen lejátszódó folyamatok részletes feltárása még várat magára. 


\subsection{Alkalmazási területek}

Annak köszönhetően, hogy a LIBS módszerrel közvetlenül mérhetők szilárd, folyadék és gáz halmazállapotú minták is, a technika igen szerteágazó területeken alkalmazható mind kvalitatív, mind kvantitatív meghatározásokra. Néhány alkalmazás meglehetősen egyedi és valóban kihasználja a LIBS által szolgáltatott előnyöket. Az alábbiakban bemutatott LIBS alkalmazások természetesen csak töredékei a szakirodalomban megtalálható munkáknak. Ezen fejezet célja nem is a teljességre való törekvés, hanem demonstrálni az általam is használt és megismert módszer előnyeit, egyszerűségét és mindenekelőtt sokoldalúságát. Az elmúlt években megjelent közleményekben a kutatók bizonyították, hogy a LIBS spektroszkópia - megfelelő készülék- és módszerfejlesztésekkel - jól helytáll a különféle alkalmazási területeken.

\section{Ötvözetek és fémipari minták}

Az ötvözetek gyártása során mind a gyártásközi minták, mind a végtermékek kémiai analízise nagyon fontos feladat. A napjainkban alkalmazott analitikai módszerek az GD-OES, XRF, SD-OES vagy ICP-AES, amelyekkel végzett mérések a legtöbb esetben külön erre a célra kialakított laboratóriumokban történnek, és az alkalmazott módszertől függően különböző mintaelőkészítési lépéseket kívánnak meg (pl. aprítás, őrlés, roncsolás, felületi csiszolás), amelyek igen időigényesek, költségesek és nagy odafigyelést igényelnek. Ezen okokból kifolyólag egyre inkább szükségessé válik egy olyan módszer kidolgozása, amely leegyszerűsíti vagy elkerüli a mintavételi és mintaelőkészítési lépéseket. A lézeralapú analitikai módszerek kulcsfontosságú szerepet játszanak az on-line módszerek fejlesztésében, mivel közvetlenül, a minták előkezelése nélkül végezhető az analízis, nincs szükség a mintával való közvetlen érintkezésre, a mérések távolról (akár néhány méterről) is történhetnek. Széleskörü ipari alkalmazása miatt a legnagyobb érdeklődést az acélminták mérése váltotta ki, de sárgaréz, arany és alumínium ötvözeteket is vizsgáltak már LIBS módszerrel. A LIBS pásztázó mikroanalízis (hibahelyek detektálása és felszíni elemanalízis) [135, 136], olvadék állapotban lévő ötvözetek analízise (magas hőmérsékletnek ellenálló szondákkal és teljesen automatizált rendszerekkel) [137, 138] és a gyártásközi alkalmazások [133, 139] érdemelnek elsősorban említést. Még tovább növelte a módszer iránti érdeklődést az ötvözetek víz alatt történő elemzésének lehetősége [71, 140].

Sturm és munkatársai [94, 132] valamint Vrenegor és társai [141] többimpulzusos LIBS-szel vizsgáltak acélötvözeteket. A három lézerimpulzust az egyik esetben [94] egy lézer, a másik esetben [132] két lézer bocsátotta ki. A harmadik esetben [141] a két lézerimpulzust egyetlen lézer hozta létre. Mindhárom elrendezésben 1064 
nm-en működő, ns impulzushosszú, Q-kapcsolós Nd:YAG lézereket alkalmaztak és a mintatartó kamrát argongázzal öblítették. A három kísérlet között a lényeges különbség a lézerek paramétereiben (teljes energia, impulzushossz) és a kísérleti berendezés összeállításában volt. A felvett analitikai görbék linearitása jó volt $\left(R^{2}>0,9\right)$, a kimutatási határok a 6-11 $\mu \mathrm{g} / \mathrm{g}$ tartományba estek, amely értékeken belső standard korrekció használatával még tovább tudtak javítani.

Lopez-Moreno és társai [126] egy hordozható mikrochip LIBS rendszer prototípusát alkalmazták acélgyártási folyamatok valósidejü elemanalízisére $(\mathrm{Cr}, \mathrm{Mo}, \mathrm{Ni}, \mathrm{Mn}$ és $\mathrm{Si}$ ). Egy miniatürizált spektrométerrel és egy iCCD kamerához kapcsolt Echelle spektrométerrel kapott eredményeket hasonlították össze. A miniatürizált spektrométerrel meghatározott kimutatási határok és relatív standard deviációk hasonlóak voltak az iCCD kamerával kapott eredményekhez. Tanulmányozták továbbá a minta hőmérsékletének hatását a spektrumvonalak intenzitására, mivel az acélgyártás során forró, olvadék állapotban lévő anyagot kell analizálni. A választott hőmérsékletek $25^{\circ} \mathrm{C}$, $300^{\circ} \mathrm{C}$ és $550^{\circ} \mathrm{C}$ voltak. A spektrumvonalak intenzitása növekedett a hőmérséklettel, azonban nem jelentek meg új vonalak, illetve a meglévő vonalak alakjában és helyzetében sem volt jelentős változás. Boltzmann-módszerrel kiszámolták a plazmák hőmérsékletét abból a célból, hogy el tudják dönteni, vajon a megnövekedett plazmahőmérsékletnek vagy a megnövekedett ablációnak köszönhető-e a jelnövekedés. A plazmahőmérsékletben nem volt jelentős változás (200 K növekedés, ha a minta hőmérsékletét $300^{\circ} \mathrm{C}$-ról $550^{\circ} \mathrm{C}$-ra emelték), így a jelnövekedés valószínüleg a megnövekedett abláció következménye.

Balzer és társai $[133,142]$ a LIBS két érdekes alkalmazását mutatták be az acélgyártás on-line követése során: a bevonat vastagságának mérését galvanizált acéllemezeken valamint az Al mélységi profiljának monitorozását tűzihorganyzott acéllemezekben. Mindkét kísérletsorozat alatt biztosították az ipari körülményeket, pl. a mintákat úgy mozgatták a lézer alatt, mint ahogy az a gyártósoron is történik. Ez a két tanulmány is mutatja, hogy a LIBS jól alkalmazható ezekben az ipari folyamatokban, és a röntgenfluoreszcenciával szemben megvan a lehetősége a könnyű elemek (pl. alumínium) vizsgálatának is.

Galbács és társai [105] egy új kalibrációs módszer használatát javasolták kétkomponensü ötvözetekben az alkotóelemek koncentrációjának meghatározására. A módszer a korrelációs koefficiensnek az elemek koncentrációjától való függésén alapul (1.3.2.3. fejezet). Az eljárás alkalmazhatóságát sárgarézötvözetek réztartalmának meghatározásával demonstrálták. A módszer mind a kétkomponensü, mind a többkomponensü ötvözetek esetében jó eredményeket szolgáltatott, annak ellenére, hogy azt eredetileg csak kétkomponensü rendszerekre találták ki. A kalibrációs görbék jó 
illeszkedést mutattak $\left(R^{2}>0,99\right)$ és azáltal, hogy az eljárás kiküszöböli a jelingadozás hatását, a görbék reprodukálhatósága is jelentősen javult.

\section{Környezetkémiai alkalmazások}

A LIBS környezetkémiai analízisekben való alkalmazása iránti érdeklődés elsősorban annak köszönhető, hogy a módszer alkalmas az in-situ terepen történő analízisekre és a méréseket megelőzően nincs szükség a minták elroncsolására. A mátrixhatás okozta zavarásokkal számolni kell, de ezek a problémák egy belső standard vagy más alternatív kalibrációs módszerek használatával elkerülhetők. A szakirodalomban megjelent legtöbb ide vonatkozó kézirat víz- és talajminták [143-148] LIBS analízisét írja le.

Niu és társai [149] tengeri alga minták stroncium tartalmának meghatározását végezték el. Az utóbbi években megnőtt az érdeklődés egy hatékony, tengeri organizmusok Sr tartalmának analízisére alkalmas módszer fejlesztése iránt, mivel ez az elem nagyon fontos ökológiai és nukleáris hulladék indikátor. A szerzők a Sr tartalom méréséhez a standard addíciós kalibráció módszerét választották. A minták elkészítése során kétféle tengeri alga standard részleteihez három különböző koncentrációjú standard Sr oldat kis térfogatát adták, majd ezután összekeverték cellulózzal és tablettát készítettek belőle. A LIBS eredmények jól egyeztek a bizonylatolt koncentrációkkal, az RSD értékek $5 \%$ körül voltak, az analitikai görbék linearitása is jó volt $\left(R^{2}>0,99\right)$.

Barbini és társai [150] tengeri üledékek elemanalízisére építettek egy terepen alkalmazható LIBS készüléket, amelyet egy antivibrációs egységgel láttak el, hogy csökkentsék a hajók mozgása által kifejtett hatást. Biológiai és földrajzi szempontból fontos az analízisek ezen típusa, hiszen információval szolgál az elemek rétegződéséről. Először kvalitatív mérésekkel meghatározták az üledékekben jelenlévő elemeket, amelyek a következők voltak: $\mathrm{Si}, \mathrm{Al}, \mathrm{Fe}, \mathrm{Mg}, \mathrm{Mn}, \mathrm{Na}, \mathrm{Ti}, \mathrm{Ba}, \mathrm{Sr}, \mathrm{Ca}$, valamint kis mennyiségben $\mathrm{Sn}, \mathrm{Pb}, \mathrm{Cd}, \mathrm{Cu}, \mathrm{V}$ és $\mathrm{Cr}$. Ezután a mélységi eloszlás fél-kvantitatív feltérképezése következett, majd normalizációs módszert alkalmaztak, hogy csökkentsék a felületek egyenetlenségének, a lézer instabilitásának és a minták más egyéb tulajdonságainak a hatását. A Ba koncentrációja mutatta a legnagyobb csökkenést a mélység függvényében. Kvantitatív méréseket is végeztek, amelyek során a kapott értékeket egy korábbi munkájukban [151] demonstrált önabszorpciós modell segítségével korrigálták.

Napjaink környezetszennyezésének jelentős részét a kőolajipar és az olajipari termékek okozzák, amelyek kis mennyiségben ugyan, de tartalmaznak különböző fémeket ( $\mathrm{Cu}, \mathrm{Ni}, \mathrm{As}, \mathrm{Be}, \mathrm{Mo}, \mathrm{Zn}, \mathrm{Cr}, \mathrm{Sb})$ is. Ezen elemek képesek felgyülemleni és visz- 
szafordíthatatlan károsodást okozni az emberi szervezetben. A nem lebomló olajipari hulladékok évekig a kőzetekben maradnak és elszennyezik vízkészleteinket vagy a táplálékként szolgáló tengeri halakban is éppúgy megtalálhatók a szennyezőanyagok. Az utóbbi időben ICP-MS-t használnak az analízisekre. Gondal és társai [152] nyersolaj maradványok elemanalízisére alkalmazta a LIBS módszert. A szerzők nyolc mikrokomponens koncentrációját határozták meg LIBS-szel és ICP-AES-sel : Ca, Fe, $\mathrm{Mg}, \mathrm{Cu}, \mathrm{Zn}, \mathrm{Na}, \mathrm{Ni}$ és Mo. Atmoszférikus és vákuumdesztillációt követően a nyersolaj maradékok pasztáiból korong alakú mintákat készítettek, míg a kalibrációhoz KBr-ból és a tiszta fémek különböző mennyiségű poraiból készített tablettákat használtak. A meghatározott koncentrációk általában jó egyezést mutattak az ICP-AES eredményekkel és a kimutatási határok is alacsonynak bizonyultak $(2-14 \mu \mathrm{g} / \mathrm{g})$.

\section{Régészeti minták és mütárgyak}

A kulturális örökségek megőrzésének és restaurálásának területén egyre inkább nő a kereslet a nem destruktív analitikai módszerek iránt. Nagyon fontos a festett felületek összetételének a meghatározása (a színező- és adalékanyagok azonosítása) ahhoz, hogy megfelelően restaurálhassák azokat (pl. olajfestmények, kerámiák, freskók). Hasonlóan, az antik ötvözetek összetételének és azok környezeti hatásokra történt átalakulásának ismerete mind múzeumi dokumentáció, mind megőrzési célokból nagyon fontos. Ezeken a területeken a LIBS módszer előnye az általában alkalmazott analitikai módszerekkel szemben (SEM, XRF, XRD, ICP-AES, ICP-MS vagy Raman mikroszkópia) elsősorban a mintaelőkészítés nélküli közvetlen analízis lehetőségében rejlik. További előnyöket jelent az in-situ mérések lehetősége, a nagy térbeli felbontás és a gyorsaság. Azt is érdemes megemlíteni, hogy a LIBS technikával szimultán elvégezhető a mütárgyak tisztítása (leggyakrabban szintén lézerekkel végzik) és az ablált anyag összetételének a meghatározása, ezáltal elkerülhető a mütárgyak jelentősebb károsodása. 2001-ben egy kézirat [153] összefoglalta a LIBS müvészeti és régészeti vonalon való alkalmazásait, de azóta is jelentős számú publikáció jelent meg ezen a területen.

Melessanaki és társai [154] közép és észak krétai ásatások során talált kerámiákat, ékszereket és fémből készült műalkotásokat vizsgáltak LIBS-szel. A tanulmány azt mutatja, hogy a spektrális adatok kvalitatív és gyakran fél-kvantitatív elemi összetételt is adnak. A színes mázzal bevont kerámiák esetében a színezőanyagokat vizsgálták, míg a fémtárgyak és ékszerek esetében a fémet vagy fémötvözetet azonosították. A munka demonstrálja a LIBS módszer alkalmasságát az archeológiai tárgyak rutin, gyors, in-situ vizsgálatára, amely lehetővé teszi a különböző típusú műtárgyak 
jellemzését és osztályozását.

Bicchieri és munkatársai [155] azurit és lazurit alapú színezőanyagokat (kék színezőanyagok középkori kéziratokban) vizsgáltak LIBS-szel és mikro-Raman spektroszkópiával. Megmutatták, hogy ez a két módszer tökéletes kiegészítői egymásnak: meghatározható a molekulaszerkezet és az elemi összetétel. Ezen felül a LIBS-szel kivitelezhető mélységi eloszlásvizsgálat is érdekes lehet a festmények és kéziratok analízisénél.

Colao és csoportja [156] középkori mázas umbriai agyagkészítményeket, románés modernkori rézalapú ötvözeteket vizsgáltak. Fél-kvantitatív analízist végeztek a többrétegü kerámiákon a mázra, a zománcra és a dekorációként jelenlévő festékekre koncentrálva. Az antik kerámiákon végzett vizsgálatok azt mutatják, hogy a LIBS mérések lehetővé teszik mind a máz, mind a dekoratív réteg összetételének félkvantitatív meghatározását, a felhasznált anyagok osztályozását.

\section{Ürkutatás}

A LIBS módszer a bolygók kőzettani elemzésének tekintetében is új lehetőségeket kínál. A korábbi ürküldetésekben alkalmazott elemanalitikai módszerek (XRF, APXS) korlátozott mennyiségű adatot tudtak gyűjteni és a minták elhelyezkedése is problémát okozhatott, mivel ezek a berendezések megkövetelik, hogy a detektor közel legyen a céltárgyhoz ( $1 \mathrm{~cm}$-en belül). Így a LIBS legfőbb előnye az előbb említett módszerekkel szemben a távolról is megvalósítható mérések lehetősége. További előnyt jelent, hogy mind a mállott, mind az alatta elhelyezkedő kőzet összetétele vizsgálható mélységi profilozással (ismételt abláció). Ahhoz, hogy a LIBS berendezést leszálló egységeken és mozgó robotokon lehessen alkalmazni az űrben, az analitikai teljesítőképesség vizsgálatát és a készülékfejlesztéseket több szempont figyelembevételével kell kivitelezni: méret, tömeg, teljesítmény és a környezet atmoszférájának minősége és nyomása.

Sallé és társai [157] végeztek egy tanulmányt bizonylatolt összetételű talaj- és agyagmintákon csökkentett nyomáson $\left(9,21 \cdot 10^{-3}\right.$ atm nyomású $\mathrm{CO}_{2}$-ban, szimulálva a Mars atmoszféráját), közel vákuumban $\left(6,58 \cdot 10^{-5}\right.$ atm nyomású levegőben, szimulálva a Hold vagy az aszteroidák légkörét) és atmoszférikus nyomáson levegőben (összehasonlítás céljából). Megvizsgálták a mintát körülvevő atmoszféra nyomásának hatását az analitikai görbékre és azt tapasztalták, hogy csökkentett nyomáson is hasonlóan jó kalibrációs görbék vehetők fel mint légköri nyomáson, az emissziós jel időbeli felbontása nélkül. A legjobb lineáris regressziós koefficienst és reprodukálhatóságot a csökkentett nyomású $\mathrm{CO}_{2}$-ban végzett mérések adták. 
Egy másik tanulmányukban Sallé és társai [81] in-situ Mars analízisek elvégzésére alkalmas LIBS müszer fejlesztésével foglalkoztak. Két különböző kísérleti elrendezés teljesítőképességét tesztelték. Az egyikkel alumínium és bazalt kvalitatív analízisét végezték el 3-12 m távolságokból. A fö alkotóelemek ( $\mathrm{Si}, \mathrm{Fe}, \mathrm{Al}, \mathrm{Mg}, \mathrm{Ca}, \mathrm{Na}, \mathrm{K}$ ) még 12 méteres távolságból is jól detektálhatók voltak, míg az alacsonyabb koncentrációban jelenlévők legtöbbje $(\mathrm{Ti}, \mathrm{Mn}, \mathrm{Cr}) 8$ méter távolságig volt kimutatható. $\mathrm{A}$ másik elrendezéssel kvantitatív méréseket végeztek. Kalibrációs görbéket vettek fel alumínium ötvözeteken olyan elemekre, amelyek kisebb vagy nagyobb mennyiségben jelen vannak a kőzetekben ( $\mathrm{Si}, \mathrm{Mg}, \mathrm{Cr}$ ). A kapott kimutatási határok nagyon hasonlók voltak az irodalomban található, más standard LIBS berendezésekkel meghatározott értékekhez.

Számos elem vonala ( $\mathrm{pl}$. $\mathrm{Br}, \mathrm{C}, \mathrm{Cl}, \mathrm{P}, \mathrm{S}$ ), amelyek a geológiai vizsgálatok szempontjából jelentősek, a VUV spektrális tartományban (100-200 nm) találhatók. Radziemski és munkatársai [77] ebben a tartományban vizsgálta ezen elemek emiszszióját egy $9,18 \cdot 10^{-3}$ atm nyomású $\mathrm{CO}_{2}$-dal megtöltött kamrában (marsi atmoszféra), mivel a szén-dioxidnak 115-165 nm között jelentős elnyelése van és ezáltal csökkenti az ebben a tartományban emittáló elemek spektrumvonalainak intenzitását.

\section{Gyógyszeripari termékek}

A gyógyszeripar termékeinek precíz minőségellenőrzését követeli meg. A gyógyszerkönyvi standard szerint egy tabletta hatóanyagának a koncentrációja a csomagoláson feltüntetett éték 95-105\%-a között változhat. A többi komponens (pl. töltő-, színező-vagy fényezőanyagok) ellenőrzése is nagyon fontos, hiszen ezek határozzák meg a tabletta mechanikai tulajdonságait, továbbá vannak olyan készítmények, amelyek multifunkcionális bevonattal rendelkeznek, így ezek vastagsági kontrollja is lényeges. A legtöbb gyógyszeripari analitikai meghatározásra a HPLC az elfogadott módszer. A HPLC-n kívül ICP-AES-t vagy GF-AAS-t szoktak még alkalmazni, amelyek szintén igénylik a minták előkészítését. Ezzel szemben a LIBS méréseket megelőzően erre nincs szükség és az analízis idő rövid, így alkalmazható akár a gyártósoron is és néhány perc alatt képes hasznos információkat szolgáltatni.

St-Onge és társai [158] demonstrálták a LIBS alkalmasságát többkomponensű tabletták gyors, kvantitatív analízisére. Azt is megmutatták, hogy egyszerű módszerekkel növelhető a módszer analitikai teljesítőképessége. A szén emissziós vonalát belső standardként alkalmazva csökkenthető volt a mátrixhatás, továbbá javítható volt a kalibrációs görbék linearitása, ha a plazma folytonos emisszióját használták, mint belső standard. Végül, ha halogéneket tartalmazó hatóanyagok mérése során hélium 
atmoszférában hozták létre a plazmát, a jel/háttér viszony nyolcszorosára növekedett.

Mowery és társai [159] a LIBS módszert tablettabevonatok vastagságának gyors meghatározására használták. A tablettában lévő Ca és a bevonat által tartalmazott Ti, Si és $\mathrm{Mg}$ emissziós spektrumát a lézerimpulzusok számának függvényében, a minta ugyanazon pontján vették fel. Az individuális lézerimpulzusok behatolási mélységét profilometriás mérésekkel állapították meg. A Ca vonalának megjelenéséből és a bevonatban jelenlévő elemek vonalainak intenzitáscsökkenéséből következtettek a rétegvastagságra. Az eredmények azt mutatták, hogy 100 mg-os tablettáknál, ahol a bevonatok vastagsága 5-21\% között változott, a vastagságban $2 \mathrm{~m} / \mathrm{m} \%$-nál kisebb eltérés is könnyen detektálható volt. A mérési idő igen rövidnek bizonyult, 15 perc alatt analizáltak 10 tablettát.

\section{Orvostudományi és biológiai alkalmazások}

Alacsony koncentrációban előforduló elemek, mint például a Zn, Ca és Fe fontos szerepet játszanak a sejtciklusokban, a sejtek anyagcseréjében és az apoptózisban (programozott sejthalál). Ezzel kapcsolatban számos analitikai módszerrel elvégezték már pl. a bőr/hámsejtek elemanalízisét (XRMA, STEM, XRF, NAA, PIXE). Sun és társai [160] a LIBS technika alkalmasságát vizsgálták a bőr hámjának legkülső rétegében (stratum corneum) végzett elemanalízisre. A szerzők a cinket választották a méréseikhez. A kalibrációhoz a mikroszkóp tárgylemezeket poli-(metil metakriláttal) vonták be, majd ezen oszlatták el centrifuga segítségével a Zn standard oldatokat. A felvett kalibrációs egyenes linearitása jó volt $\left(R^{2}=0,998\right)$ és a kimutatási határ értéke 0,3 $\mathrm{ng} / \mathrm{cm}^{2}$-nek adódott. Több önként jelentkező alkarjára cinkoldatot vagy cinkkenőcsöt tettek és rajta hagyták 0,5 és 2,75 óráig. Ezután fájdalommentesen, cianoakrilát ragasztó segítségével hat, egyenként 2-3 $\mu \mathrm{m}$ vastagságú bőrréteget eltávolítottak az alanyok karjáról és megvizsgálták LIBS-szel. Az eredmények azt mutatták, hogy a Zn felszívódott a bőrön keresztül és koncentrációja exponenciálisan csökkent az alsóbb bőrrétegek felé haladva.

Sajnos napjainkra a rák népbetegséggé nőtte ki magát, ezért nagyon fontos lenne egy olyan diagnosztikai eljárás, amely gyorsan, in-situ információt szolgáltatna az orvosok számára és a páciensnek nem kellene várni a szövettani eredményre. Tudomásom szerint Kumar és csoportja [161] elsőként alkalmazta a LIBS módszert egészséges és rosszindulatú sejtek megkülönböztetésére. Módszerük azon a megfontoláson alapul, hogy a kétféle sejtben az elemek koncentrációinak arányai (főleg $\mathrm{Ca} / \mathrm{K}$ és $\mathrm{Cu} / \mathrm{K})$ jelentősen különböznek. A bíztató tapasztalatok arra sarkallták a szerzőket, hogy próbálkozzanak egy új, in vivo használható LIBS diagnosztikai módszert kifejlesztésével. 
Aeroszolok mérése

Az apró szemcséjü nehézfémeket tartalmazó aeroszolok belégzése toxikus vagy karcinogén hatást fejthet ki az emberi szervezetben, ezért az ipar számára fontos egy gyors, on-line analitikai eljárás, amely képes a részecske kibocsátást ellenőrizni. Mivel az ultrafinom nehézfém aeroszolokban az analit tömege nagyon kicsi a térfogathoz képest, az elemi összetétel rutinszerű meghatározása ma szűrővel történő mintavétellel kezdődik, majd a minta roncsolásával folytatódik, végül AAS-el, ICP-AES-el vagy ICP-MS-el történik az elemanalízis. Neuhauser és társai [40] egy mobil LIBS rendszert fejlesztettek ki aeroszol szűrők közvetlen analízisére. Mielőtt a berendezést elhelyezték volna a hulladékégetőnél, laboratóriumi mintákkal kalibrálták. Az emissziós vonalak kiválasztásánál nagy figyelmet fordítottak az aeroszolszürőben található elemek vonalainak zavaró hatására. Tizenkét, a kiáramló gázok által tipikusan tartalmazott elem ( $\mathrm{Cd}, \mathrm{Ni}, \mathrm{As}, \mathrm{Co}, \mathrm{Mn}, \mathrm{Sb}, \mathrm{Cr}, \mathrm{Tl}, \mathrm{Sn}, \mathrm{V}, \mathrm{Cu}, \mathrm{Pb}$ ) vonalát választották ki, felvették a kalibrációs görbéket, amelyek alapján számított kimutatási határok 0,01-0,04 $\mathrm{\mu g} / \mathrm{cm}^{2}$ között változtak. A hulladékégető által kibocsátott gázból vett mintákban csak vasat és rezet tudtak detektálni, a többi elem koncentrációja a kimutatási határ alatt volt. Az eredményeik azt mutatták, hogy a LIBS berendezésük további fejlesztésekkel, amelyek a kimutatási határokat csökkentik, alkalmas lehet nehézfémtartalmú aeroszolok mérésére.

Mukherjee és munkatársai [162] kidolgozták a LIBS kvantitatív alkalmazását nanoaeroszolok összetételének a jellemzésére egy belső standard segítségével. Kísérleteik célja volt megtalálni az optimális késleltetési időt minden meghatározandó elem spektrumának a felvételéhez és ugyanolyan körülmények között mérni a plazma hőmérsékletét és a háttérgáz sürüségét. Ezek lehetővé tették a különböző kísérleti körülmények hatásának, a különböző energiaállapotú specieszek gerjesztésének, a plazmatérfogat időbeli változásának és a műszerjellemzők hatásának a kiküszöbölését. A kísérleti rendszerük lehetővé tette a nanorészecskék energetikai tulajdonságainak a megértését, különösen a passziválódott bevonat (fém-oxidok) reaktivitását és stabilitását. A módszert sikeresen alkalmazták alumínium nanorészecskék esetén az oxidáció mértékének kvantitatív megbecslésére.

Katonai és anti-terrorista alkalmazások

A taposóaknák a világ sok országában azután is problémákat okoznak, miután a katonai tevékenységek véget értek. Évente több mint 90 országban kb. 15000 20000 ember esik áldozatául az aknáknak. Ráadásul a felkutatásuk is nagy vesződséggel jár, hiszen a szemben álló erők nem szoktak pontos térképeket rajzolni az el- 
helyezett aknákról. Ezen kívül legtöbbjük olyan kevés fémet tartalmaz, hogy csak a legérzékenyebb fémdetektorok képesek azokat észlelni. Ezért kutatják gyors, olcsó, de egyben megbízható felderítési módjukat.

Harmon és csoportja [163] taposóaknák detektálására és megkülönböztetésére alkalmazta a LIBS módszert. Munkájukat egy laboratóriumi berendezés és egy hordozható készülék prototípusával végezték. Különböző gyártóktól származó gyalogos katonák és harckocsik elleni aknák burkolatainak, a talajban természetes körülmények között előforduló anyagoknak - úgymint műanyagok, kőzetek, fém tárgyak és cellulóz alapú anyagok - a spektrumait gyüjtötték össze. Két laboratóriumi tesztet végeztek, amelyben 100 spektrumot rögzítettek és összehasonlították ezeket egy adatbázis spektrumaival. Lineáris korreláció alkalmazásával az „akna/nem akna” meghatározások mindkét kísérlet során a minták több mint 90\%-ánál helyes eredményt szolgáltattak. Végeztek egy hasonló tesztet a hordozható berendezéssel is, amely analóg eredményeket szolgáltatott, tehát a LIBS módszer ezen alkalmazása sikeresnek bizonyult.

A veszélyes biológiai anyagok - baktériumok, vírusok, biotoxinok és gombák detektálása mind civil (pl. terrorizmus), mind orvosi és ipari szempontból fontos. Gyors, érzékeny és szelektív módszerre van szükség, amely rövid időn belül felismeri a veszélyes anyagokat. Az általánosan alkalmazott módszerek legtöbbje valamilyen biokémiai, mikrobiológiai vagy immunológiai folyamaton alapul, amelyek megfelelően érzékenyek és megbízhatóak, de a leggyakrabban időigényesek és specifikusak, így korlátozzák egy vagy több összetevő detektálását. Mintaelőkészítést is igényelnek, amely a munkát végző személy veszélyeztetésével vagy a minta elszennyezésével járhat.

Baudelet és társai [164] ebből a célból az Escherichia coli baktériumot tanulmányozták LIBS-szel. Munkájukban demonstrálták, hogy a CN kötés kinetikai vizsgálata lehetőséget nyújt arra, hogy megállapítsák a baktériumtól származó jel hozzájárulását a teljes CN jelhez. A spektrális információk összessége (atomvonalak, CN molekulasávok) ujjlenyomatként szolgálhat a tanulmányozott baktérium azonosításában. A szerzők rámutattak arra is, hogy az intramolekuláris kötések kinetikájának a megfigyelése célra vezető minden olyan minta esetében, amelyekben molekuláris funkciós csoportok találhatók.

\section{Bünügyi laboratóriumi analízis}

A különböző anyagok elemanalízise fontos bizonyítékokat szolgáltat a bünügyi eljárások során. A helyszínen összegyűjtött bizonyítékoknak, pl. a betörések, cserbenhagyásos gázolások helyszínén talált üvegszilánkok, fegyverrel elkövetett bűntettek 
esetében a lőpormaradványok nyomanalízise nagymértékben hozzájárul a bűncselekmények felderítéséhez. Napjainkban, a bűnügyi laboratóriumokban SEM-EDS-t, XRFet, ICP-AES-t, MS-t vagy LA-ICP-MS-t alkalmaznak. Azonban ezek igen drága berendezések, így sok laboratórium számára nehezen hozzáférhetőek. Ezért több kutatóban is felmerült a gondolat, hogy a szintén multielemes, minden halmazállapotú mintát kezelni képes, mikrodestruktív, mintaelőkészítést nem igénylő, könnyen kezelhető és relatíve olcsó LIBS megbízhatóan alkalmazható-e a bünügyi analízisekben.

Dockery és Goode [165] azt vizsgálták, hogy a lőpormaradványok kimutathatóak-e a LIBS technikával. A lőporanalízis alapja a bárium, az ólom és az antimon jelenlétének az igazolása lehet. Azonban számos olyan tevékenység létezik, amelyek során szintén rákerülnek ezek és persze más anyagok is az emberi kézre, ezért nagyon fontos, hogy lehetőleg az összes jelenlévő elem azonosítása megtörténjen. A gyanúsított kezéről egyszerüen, ragasztószalaggal vett minta közvetlenül a müszerbe helyezhető és analizálható. A lőpormaradványok detektálhatóak voltak, a szerzők egyértelműen bizonyították, hogy a LIBS megállja a helyét a lőporanalízisekben. A hibaértékeket Monte Carlo szimulációval becsülték meg és sikerült minimálisra csökkenteniük a téves azonosítások számát.

A bűnügyi laboratóriumi analízisekben az üvegből lévő bizonyítékok esetén hoszszú évek óta a törésmutató mérés a bevált módszer. Az üveggyártásban bekövetkezett technológiai fejlesztések miatt egyre kisebb a különbség a különböző üzemekből és gyártóktól származó üvegek fizikai és optikai tulajdonságaiban. Ebből kifolyólag folyamatosan csökken a törésmutató információs értéke, így szükségessé válik egy új, megbízható vizsgálati módszer az üvegminták megkülönböztetésére. Rodriguez-Celis és társai [166] azt javasolták, hogy a különböző, de hasonló törésmutatójú üvegek azonosítása történhet a LIBS spektrumuk „ujjlenyomat” tartományainak és egy statisztikus korrelációs módszernek a segítségével. Először a különböző helyszínekről származó ismeretlen üvegminták spektrumait hasonlították össze egy adatbázis spektrumaival, így azonosították azokat, majd az egyes spektrumokat egymással összevetve megállapították, hogy ugyanabból a forrásból származnak-e az üvegszilánkok. A módszerük robusztusságát a lineáris korreláció és egy spektrális maszk kombinációjával elért $100 \%$-os azonosítás bizonyítja, amely abban az esetben is megbízható volt, ha a kísérleteket különböző napokon vagy eltérő körülmények között végezték el. 


\section{Célkitúzések}

Az 1-4. és 1-5. fejezetben leírt módon, a többszörös lézerimpulzussal történő plazmakeltés módszerével jelentős teljesítőképesség növekedés érhető el a LIBS spektrometriában az SP-LIBS esethez képest. Ezt a jelenséget 2000 óta már számos tanulmány meggyőzően dokumentálta, elsősorban a technikailag könnyebben tanulmányozható/megvalósítható kétimpulzusos esetre vonatkozóan (DP-LIBS). Mindennek ellenére azonban még mindig nem teljesen tisztázott, hogy milyen részfolyamatok okozzák, illetve járulnak hozzá az analitikai teljesítőképesség nagymértékű javulásához; a szakirodalomban eltérő, némely esetben egymásnak ellentmondó megállapítások és elméletek olvashatók erre vonatkozóan. Mindennek természetesen az is az oka, hogy az egyes tanulmányokban használt LIBS kísérleti rendszerek nagymértékű változatosságot mutatnak, márpedig a magas hőmérsékletű és nagyon tranziens természetű LIB plazmákban lejátszódó folyamatokra a kísérleti körülmények jelentős hatással vannak.

Az elmondottak különösen érvényesek a kettőnél több lézerimpulzussal kivitelezett LIBS spektrometria (MP-LIBS) esetére. Az irodalomban ugyanis még nagyon kevés kísérleti adat található a kolineáris MP-LIB plazmákra és analitikai alkalmazásukra vonatkozóan, noha ezek az adatok igen ígéretesek.

Ezen okok miatt célul tűztük ki a kolineáris lézerimpulzusokkal keltett MP-LIB plazmák jellemzőinek és az MP-LIBS módszer analitikai alkalmazási lehetőségeinek vizsgálatát. Kísérleti munkám a következő három részterületre koncentrálódott:

1.) Időbeli és térbeli felbontású mérések kivitelezése abból a célból, hogy azonosíthatóvá váljanak a kolineáris MP-LIB plazmában lejátszódó azon folyamatok, amelyek felelőssé tehetők az előzetes kísérletekben tapasztalt megnövekedett analitikai teljesítőképességért.

2.) A kolineáris MP-LIBS módszer analitikai teljesítőképességének széleskörű, szisztematikus felmérése szilárd minták elemzésének esetére vonatkozóan.

3.) Analitikai módszerek kidolgozása a kolineáris MP-LIBS spektrometria alkalmazására különböző szilárd halmazállapotú minták elemösszetételének pontos meghatározására. A munka ezen részének végrehajtása során különös figyelmet szenteltem a kutatócsoportunk által korábban, fémötvözetek elemzésére kidolgozott újszerü, a lineáris korreláción alapuló kalibrációs módszer (általánosított lineáris korrelációs kalibráció, GLCM) alkalmazásának. 


\section{Műszerek, felhasznált anyagok és eszközök}

\subsection{Müszerek}

A 3-1. ábrán látható annak a laboratóriumunkban épített, többszörös impulzusokkal müködő LIBS rendszernek (továbbiakban „A" rendszer) a felépítése és fényképe, amellyel a kísérletek túlnyomó részét végeztem.
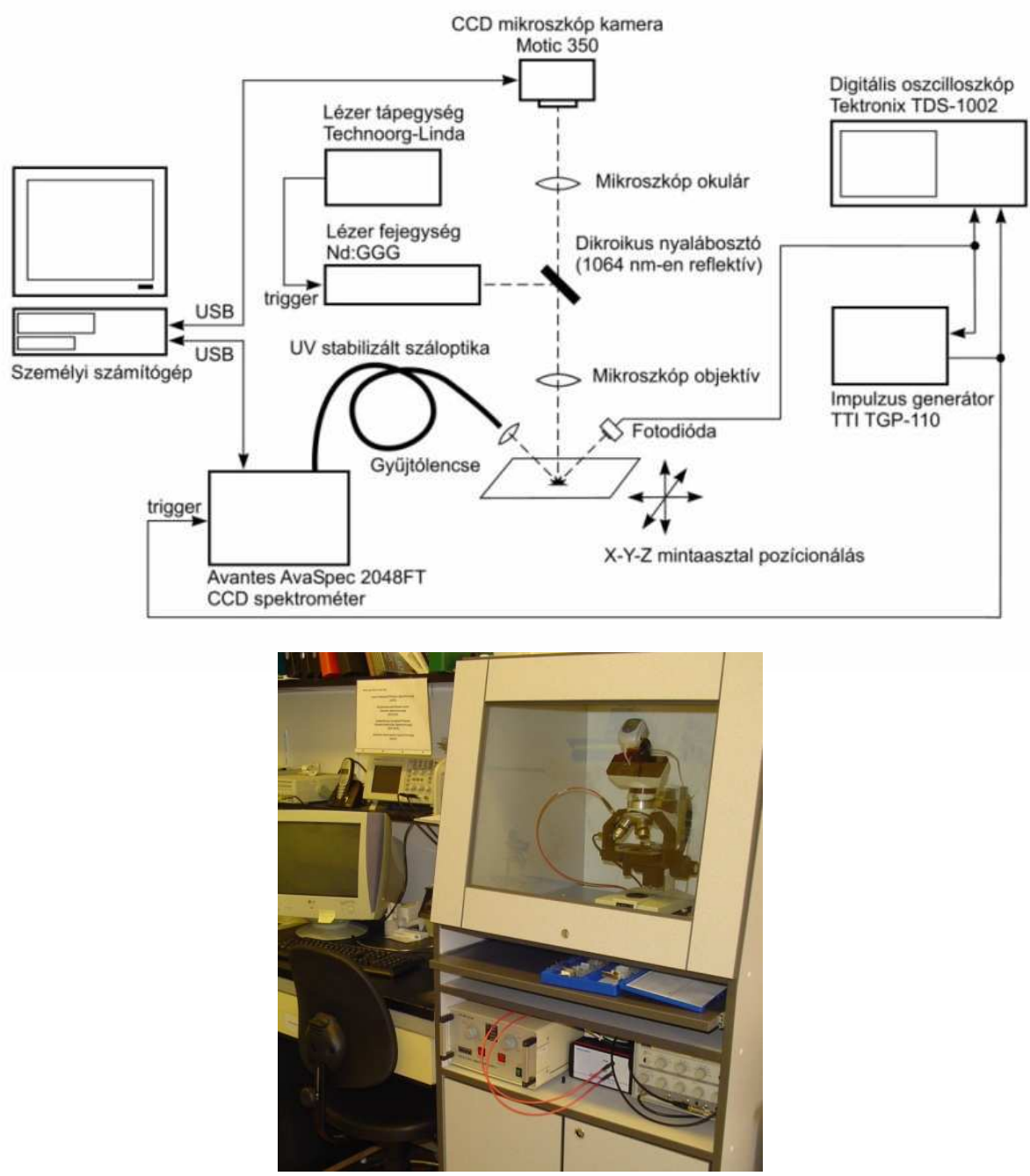

3-1. ábra: $A z$ " $A^{\prime \prime}$ kísérleti berendezés felépítése és fényképe.

A berendezés egy metallurgiás mikroszkóp köré épült (SP80, Brunel), amely lehetővé teszi a minta tárgyasztalon való mozgatását is. Műszerünkben egy infravörös, passzív 
LiF: $F_{2}^{-}$Q-kapcsolós, $1 \mathrm{~Hz}$ ismétlési sebességü, villanólámpás pumpálású, 1055 nm-en emittáló Nd:GGG lézer fényforrást (MP/G-Q-005, Technoorg-Linda) alkalmazunk, amely által kibocsátott lézerimpulzusok hossza $\approx 10$ ns és számuk 1-11 között szabályozható. A létrejött mikroplazmát száloptikás CCD spektrométerrel figyeljük meg (AvaSpec 2048FT, Avantes). A lézer fényét egy dikroikus nyalábosztó (SWP-45RU1064-TU400-750-RW, CVI Technical Optics) segítségével irányítjuk a mikroszkóp objektívre (4x, fókusztávolság: $22 \mathrm{~mm}$ ), amely a minta felületére merőleges irányból fókuszálja a nyalábot. A céltárgy felszínét ugyanezen az objektíven keresztül tudjuk megfigyelni egy digitális kamera segítségével (Model 350, Motic), amely a mikroszkóp okulárjához csatlakozik. A reprodukálható lencse-minta távolság és az optimális fénygyűjtés beállításának érdekében egy HeNe lézert (Typ 1508P-0, Uniphase) használtunk. Az optimálás során ezzel a lézerrel kivilágítottuk az Nd:GGG lézer által a mintafelszínen létrehozott krátert és ez a fényfolt segített nekünk a többi minta és a gyűjtőlencsék pontos, reprodukálható beállításában. A plazma által emittált fényt két gyűjtőlencse segítségével irányítjuk egy-egy $200 \mu \mathrm{m}$ átmérőjü, UV-stabilizált, szilíciumdioxidból készült optikai szálba. A gyűjtőlencsék $45^{\circ}$-os szöget zárnak be a mintafelület normálisával. A CCD spektrométert egy Si fotodióda (DET36A, Thorlabs) jele triggereli, amely oldalnézetből érzékeli a plazma keletkezését. A lézerimpulzusok struktúráját digitális tárolós oszcilloszkópokkal (TDS-1002, Tektronix illetve DS1102E, Rigol) figyeljük meg. Az impulzusok közötti késletetési idő hattagú impulzussorozat esetén kb. 28 s és kis mértékben emelkedik, ha kevesebb impulzussal dolgozunk. A késletetési időt egy impulzusgenerátor (TGP-110, Thurlby Thandar Instruments) segítségével szabályozzuk. Kísérleteink során általában 3,4 $\mu$ s késleltetési idővel és $2 \mathrm{~ms}$ integrációs idővel dolgoztunk: az utóbbi értéket a spektrométer CCD detektorának adatkiolvasási sebessége korlátozza. Rendszerünk időben és térben integrált adatgyűjtést tesz lehetővé mind az UV (198- $318 \mathrm{~nm}$; 0,09 nm-es optikai felbontással), mind a Vis (345-888 nm; 0,4 nm-es optikai felbontással) tartományban. A spektrumok felvétele minden esetben levegőben történik.

A 4.1.2. fejezetben található, a plazma időbeli vizsgálatára vonatkozó kísérletek egy több éve fennálló együttműködésnek köszönhetően a gainesville-i egyetemen (University of Florida, Florida, USA) épített LIBS berendezéssel (3-2. ábra, továbbiakban „B" rendszer) készültek. A műszer egy 1064 nm-en sugárzó, 4 ns hosszúságú impulzusokat kibocsátó, villanólámpás pumpálású, passzív Q-kapcsolós Nd:YAG szilárdtest lézerből (MK-367, Kigre), egy képalkotó spektrométerből (SpectraPro-500i, Acton Research) és egy ehhez csatlakoztatott iCCD kamerából (576-S/RB-E, Princeton Instruments) állt. A spektrométer $2400 \mathrm{~mm}^{-1}$ osztású ráccsal és $35 \mu \mathrm{m}$-es belépő réssel van ellátva. A fény gyüjtése $1: 1$ leképezéssel, oldalirányból történt a belépő résre. A berendezéssel lehetőség van nagy időfelbontású digitális fotók (teljesen nyitott rés) 
és térbeli felbontású emissziós spektrumok (10 nm-es ablakszélesség, 0,05 nm-es felbontás, UV tartomány) rögzítésére. A lézerfény mintára való fókuszálása mikroszkóp objektívvel (4x, Bausch and Lomb, fókusztávolság: $48 \mathrm{~mm}$ ) történt. Az adatgyűjtés triggerelését egy PIN fotodióda és egy impulzusgenerátor (HP8003A, Agilent) végezte. Az impulzusstruktúra rögzítése digitális oszcilloszkóppal (TDS 520D, Tektronix) történt. A lézerimpulzusok száma 1 és 4 között szabályozható.

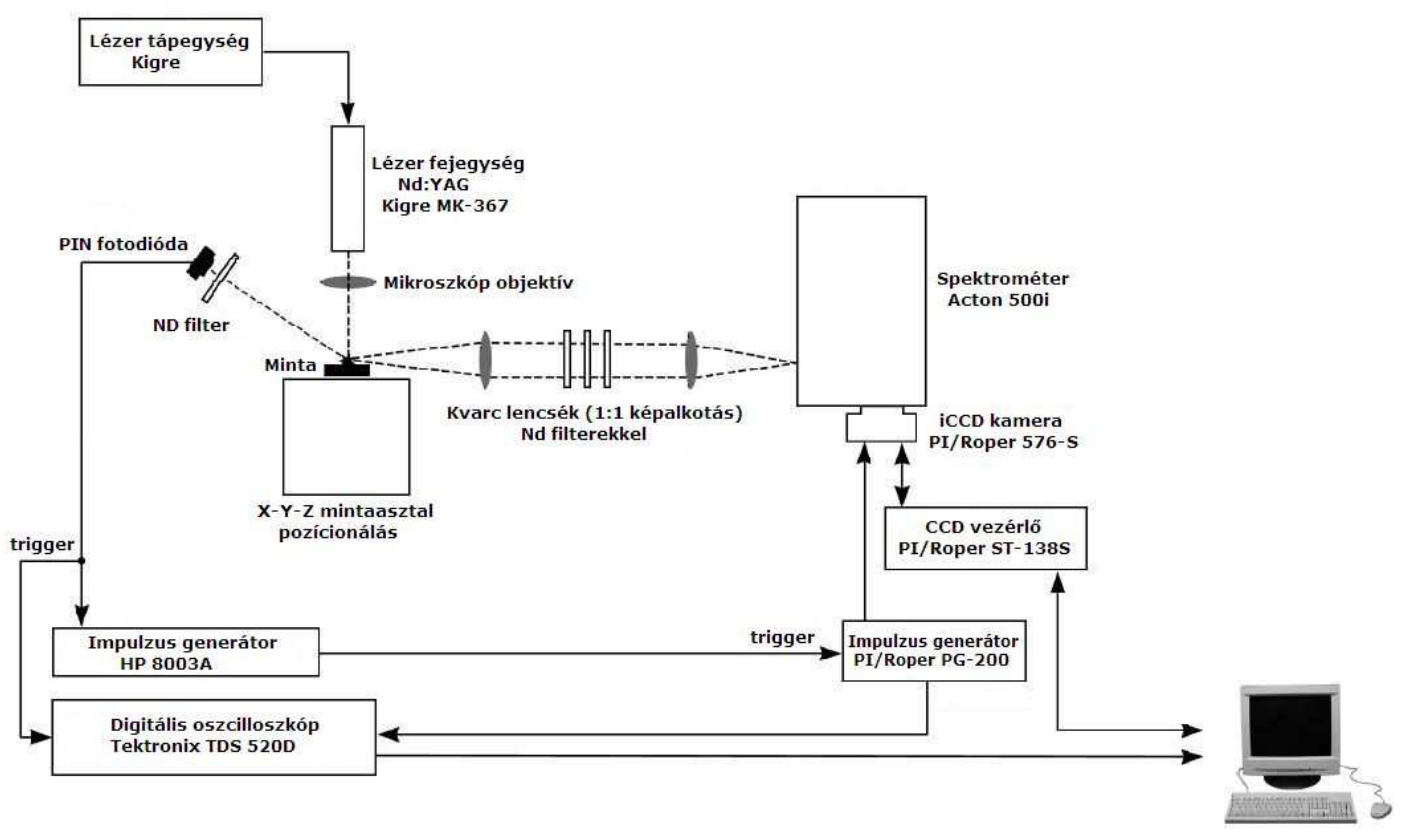

3-2. ábra: A B kísérleti berendezés felépítése.

Mindkét passzív Q-kapcsolós lézerre ("$A$ " és „B") jellemző az impulzusok intenzitáseloszlásának és követési idejének ingadozása. Az intenzitásokban kb. 10\%-os, a követési időkben pedig 10-15\%-os szórás figyelhető meg. A követési idők következetesen hosszabbak a később érkező impulzusoknál valamint akkor, ha kisebb impulzusszámmal dolgozunk. A 3-3. ábra illusztrálja mindkét lézer időbeli impulzusstruktúráját. Látható, hogy az " $A$ " rendszer lézerének ismétlési sebessége jóval kisebb, mint a " $B$ " lézeré. Mivel ezeknél a passzív Q-kapcsolós lézereknél az impulzusstruktúra szabályozására igen kevés lehetőség van, ezért bizonyos kísérleteknél (4.1. fejezet) a következetes adatgyűjtés érdekében minden esetben 20-50 mérést végeztünk, ezután pedig kiválogattuk azokat az adatokat, amelyek hasonló impulzusstruktúrájú lövésektől származtak ( $5 \%$-os tolerancia az intenzitás-eloszlásban és a követési időkben) és a kiértékelés során csak ezeket használtuk fel. Az átlagos követési idők megegyeztek a 3-3. ábrán láthatókkal. 
A

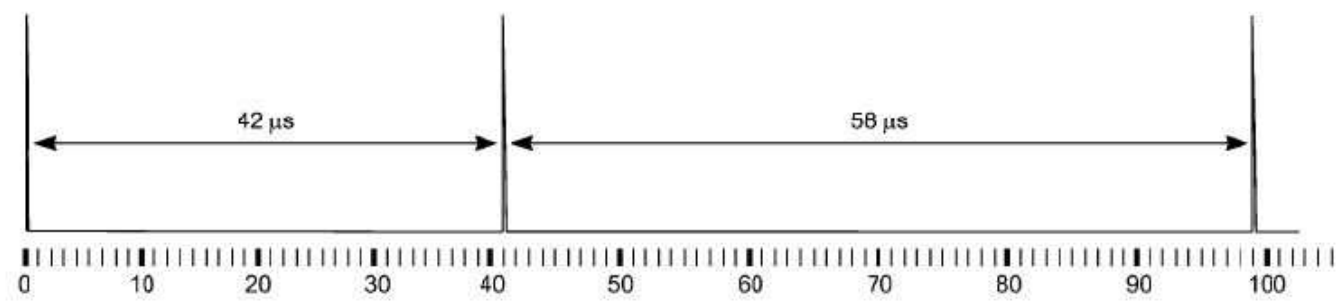

B

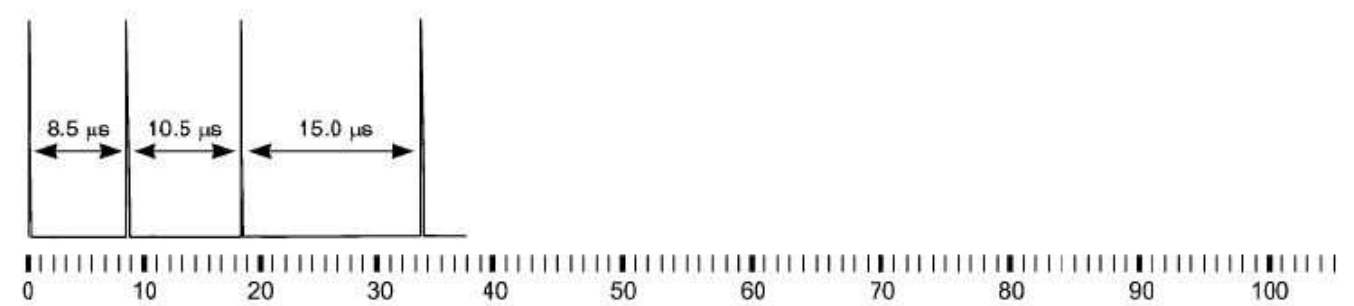

3-3. ábra: $A z$ "$A$ " és „ $B$ ” rendszerek lézereinek időbeli impulzusstruktúrája. Az időskála egysége $\mu$ s.

A profilometriás mérések szintén a gainesville-i egyetemen, egy Veeco Wyko 1000 NT típusú optikai profilométerrel történtek. A mikroszkópos felvételek nagyobbik része közvetlenül, az „ $\mathrm{A}$ ” rendszer mikroszkóp kamerájával, kisebbik része pedig egy Fischer Scientific Micromaster mikroszkópra szerelt digitális kamerával (Vitana PLA642, Pixelink) készült, száloptikás megvilágítás (Fiber-lite 190, Dolan-Jenner) mellett.

Mivel visszatérő fogalmakról van szó, ezért itt szeretném tisztázni, hogy mit értek az értekezés során a lézer "lövés" fogalma alatt. Egy lövés alatt a lézer egy alkalommal való „elsütését”, vagyis a beállított számú impulzust tartalmazó impulzussorozat kibocsátását értem. A spektroszkópiai kísérletekben egy lézer lövés egyúttal egy emissziós (UV és/vagy Vis) MP-LIBS spektrum felvételét is jelenti. 


\subsection{Felhasznált anyagok és eszközök}

> Analitikai tisztaságú fémek: $\mathrm{Al}, \mathrm{Cu}, \mathrm{Mg}, \mathrm{Si}$ és $\mathrm{Zn}$ lemezek (Reanal, Magyarország; BDH és Advent Material Research, Nagybritannia).

> Aranyötvözetek: kilenctagú, ötvösi bizonylattal rendelkező aranyötvözet sorozat, amely tagjainak jelölése és aranytartalma a következő: $8 \mathrm{~K}=334,1 \%$; $10 \mathrm{~K}=412,7 \%$ ； $12 \mathrm{~K}=506,3 \%$ ； $14 \mathrm{~K}=586,8 \%$ ； $16 \mathrm{~K}=674,2 \%$ ； $18 \mathrm{~K}=756,8 \%$ ； $20 \mathrm{~K}=838,1 \%$; $22 \mathrm{~K}=912,2 \%$ és $24 \mathrm{~K}=994,3 \%$ volt. Ezek a bizonylatolt koncentráció adatok két magyarországi fémvizsgáló hivatal által, a standardizált tűzipróba [167] módszerével meghatározott eredmények átlagai. Az ötvözőelemek aránya minden mintában állandó.

> Acélminták: hattagú, bizonylatolt összetételű acélötvözet sorozat (Vasipari Kutatóintézet, Budapest). Ezek jelölése és krómtartalma: $A 3=0,37 \%$; $A 2=0,66 \%$; $A 12=1,25 \% ; A 1=1,46 \% ; A 16=1,75 \%$ és $A 11=2,16 \%$.

> Alumíniumötvözet: SM10 jelü, 84,67\% Al, 2,9\% Si, 5,45\% Zn, 2,8\% Cu, 1,96\% $\mathrm{Fe}, 1,08 \% \mathrm{Mg}, 0,29 \% \mathrm{Mn}, 0,24 \% \mathrm{~Pb}, 0,26 \% \mathrm{Sn}$ bizonylatolt összetétellel rendelkező ötvözet (Apex Smelter Co., Dél-Afrika).

> Forrasztófémek: kereskedelmi forgalomban kapható ötvözetek, amelyek gyártója, termékszáma és összetétele a következő: CFH 52340 No. 3 (Sn 97\%, Cu 3\%), CFH 52330 (Sn 40\%, Pb 60\%), Multicore 419590 (Sn 5\%, Pb 93,5\%, Ag 1,5\%), Lux 539066 (Sn 30\%, Pb 70\%), Super Solder Wire (Sn 60\%, Pb 40\%).

> Galvanizált fémminták: kereskedelmi forgalomban kapható krómbevonatú réz és nikkelbevonatú cinkötvözetek.

> Pirolitikus grafit: nagy orientáltsági fokú, pirolitikus (HOPG) grafit lapka (Advanced Ceramics Corporation, Lakewood, OH, USA).

> Politetrafluoro-etilén (PTFE): kereskedelmi forgalomban kapható, $80 \mu \mathrm{m}$ vastagságú, 12 mm széles tömítőszalag (Schläfer, Németország).

> Polietilén (PE): BCR CRM 680, bizonylatolt összetételü műanyag standard (Institute for Reference Materials and Measurements, Belgium)

A méréseket megelőzően nem volt szükség mintaelőkészítésre. A mintadarabokat kétoldalú ragasztóval (TESA) mikroszkóp tárgylemezre rögzítettük és a mérések előtt a felületüket analitikai tisztaságú acetonnal vagy etanollal letöröltük.

A spektrumvonalak azonosítását a Peax v2.0 spektroszkópiai program (Systematix $A B$ ) segítségével végeztem, amely a NIST (National Institute of Standards and Technology) adatbázist használja, az intenzitásadatok leolvasása pedig a spekt- 
rométer mérőprogramjában (AvaSoft 7.4, Avantes) történt. Referenciaként az on-line Kurucz adatbázist is használtuk. Minden más adatkiértékelést és az adatok ábrázolását a Microsoft Office Excel 2003 (Microsoft) és az Origin 7.5 (OriginLab) szoftverekkel végeztem. 


\section{Eredmények és értékelésük}

\subsection{Az ablációs folyamatok és a plazmák térbeli, időbeli jellemzőinek vizsgálata}

A DP-LIBS irodalomban az SP-LIBS-hez képest tapasztalt, a plazma- és emissziós jellemzők megfigyelt változásainak okaira vonatkozó felvetések (1.4. fejezet) három csoportba, a lézer-minta, a lézer-plazma és a lézer-aeroszol kölcsönhatások csoportjába sorolhatók. Feltételezhető, hogy hasonló alapvető folyamatok játszódnak le az MP-LIBS során is.

A lézer-minta kölcsönhatások közé sorolhatók azok a mintafelületen vagy annak közelében bekövetkező változások, amelyek eredménye az ablációs jellemzők megváltozása. Az első és legfontosabb kérdés természetesen annak eldöntése, hogy vajon egyáltalán történik-e ismételt abláció. Ez nem nyilvánvaló, ugyanis a lézer-plazma és lézer-aeroszol kölcsönhatások dominanciája esetén előfordulhat, hogy az elsőt követő későbbi lézerimpulzusok energiájának legnagyobb része nem éri el a mintafelszínt. Amennyiben igen, akkor a mintafelület kondicionálódása (pl. felmelegedése, a felület fizikai/optikai jellemzőinek megváltozása kémiailag módosult ablációs törmelék lerakódása miatt, stb.) vagy a minta felett a nyomás-lökéshullám hatására időlegesen kialakuló nyomásesés miatt az ablációs/letörési küszöbenergia megváltozik, ezért várható, hogy a második/harmadik, stb. plazma jellemzői jelentősen eltérnek majd az elsőétől. A lézer-plazma kölcsönhatás elsősorban a plazma specieszeknek a követő lézerimpulzusok energiájának elnyelése miatt bekövetkező újra/tovább gerjesztését jelenti. A lézer-aeroszol kölcsönhatások közé a korábbi impulzusok által ablált anyag (kilökődött részecskék vagy olvadékcseppek, továbbá a plazma lehűlésekor keletkező kondenzációs részecskék) tovább ablálódásából származó effektusokat soroljuk.

A jelen fejezetben bemutatott kísérleteink célja az volt, hogy a fenti részfolyamatoknak a kolineáris MP-LIB plazmákban betöltött szerepének tisztázása érdekében adatokat gyűjtsünk. Ezeket a kísérleteket két LIBS rendszeren, idő, térbeli és spektrális felbontás alkalmazásával végeztük el, többféle fémes minta alkalmazásával.

\subsubsection{Az ablációs jellemzők tanulmányozása}

$A z$ egy lövésen belüli impulzusok számának függvényében, az " $A$ " rendszerrel vizsgáltuk az ablációs mélységet krómozott réz és nikkelezett cinkötvözet céltárgya- 
kon. A mérések célja különböző impulzusszámnál (1-7) a fémbevonat átlyukasztásához szükséges lövésszám meghatározása volt. Ez az érték megközelítőleg fordítottan arányos a lövésenkénti ablációs mélységgel. A mérések során a Cu (I) 521,8 nm-es és a Zn (I) 481,0 nm-es vonalának megjelenésével indikáltuk a fémbevonat réteg átütését. A kísérleti adatokat a 4-1. ábra szemlélteti. Az átütéshez szükséges lövésszám egyértelmű csökkenése (az ablációs mélység növekedése) látható, minél több impulzusból álló sorozattal dolgoztunk. A növekedés gyorsabb a lineárisnál, amely arra enged következtetni, hogy a mélység növekedése nem csupán a nagyobb, teljes bevitt energia következménye. Más szóval, az impulzusszámmal normált ablációs mélység is növekedést mutat az impulzusszám növelésével. Ez a megfigyelés összhangban van más, olyan kutatócsoportok MP-LIBS ablációs megfigyeléseivel is, akik hasonló impulzuskövetési időkkel dolgoztak [124, 125].



4-1. ábra: Fémbevonat átütéséhez szükséges lövések száma az impulzusszám függvényében $(\bullet)$ krómozott réz minta és (O) nikkelezett cinkötvözet minta esetében.

A hibasávok 5 párhuzamos mérés szórását jelölik.

Megvizsgáltuk az ablációs kráterek morfológiáját is fehérfény profilometria és fénymikroszkóp alkalmazásával. Ebben a kísérletsorozatban a kráterek réz mintán készültek, 10 különböző impulzusszámú ismételt lövéssel, illetve 40 egyimpulzusos

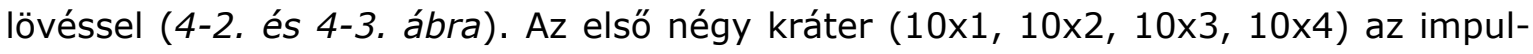
zusstruktúra ablációra gyakorolt hatásáról szolgál információval, míg az ötödiket (40x1) az elsővel (10x4) összehasonlítva azt az esetet vizsgálhatjuk, amikor különbö- 
ző impulzusszámú lövések mellett a teljes impulzusszám, vagyis a teljes bevitt energia azonos. A lézer ismétlési sebessége mindegyik esetben $1 \mathrm{~Hz}$-nél kisebb volt.

Amint az a 4-2. ábrán is látható, a többszörös impulzusokkal létrehozott kráterek morfológiája nagyon hasonló az egyimpulzusoshoz. Keresztmetszetük az x-y síkban közel kör alakú, míg a z-irányban (mélység) nagyjából háromszög alakú és a kráter pereme körül felfedezhető némi visszarakódott anyag. A fénymikroszkópos felvételeken (4-3. ábra) láthatóak a hőhatás következtében, a kráterek körül kialakult elszíneződések és dilatációs redők is, amelyek a kráter körül az átmérő többszörösének megfelelő távolságig is észlelhetők.
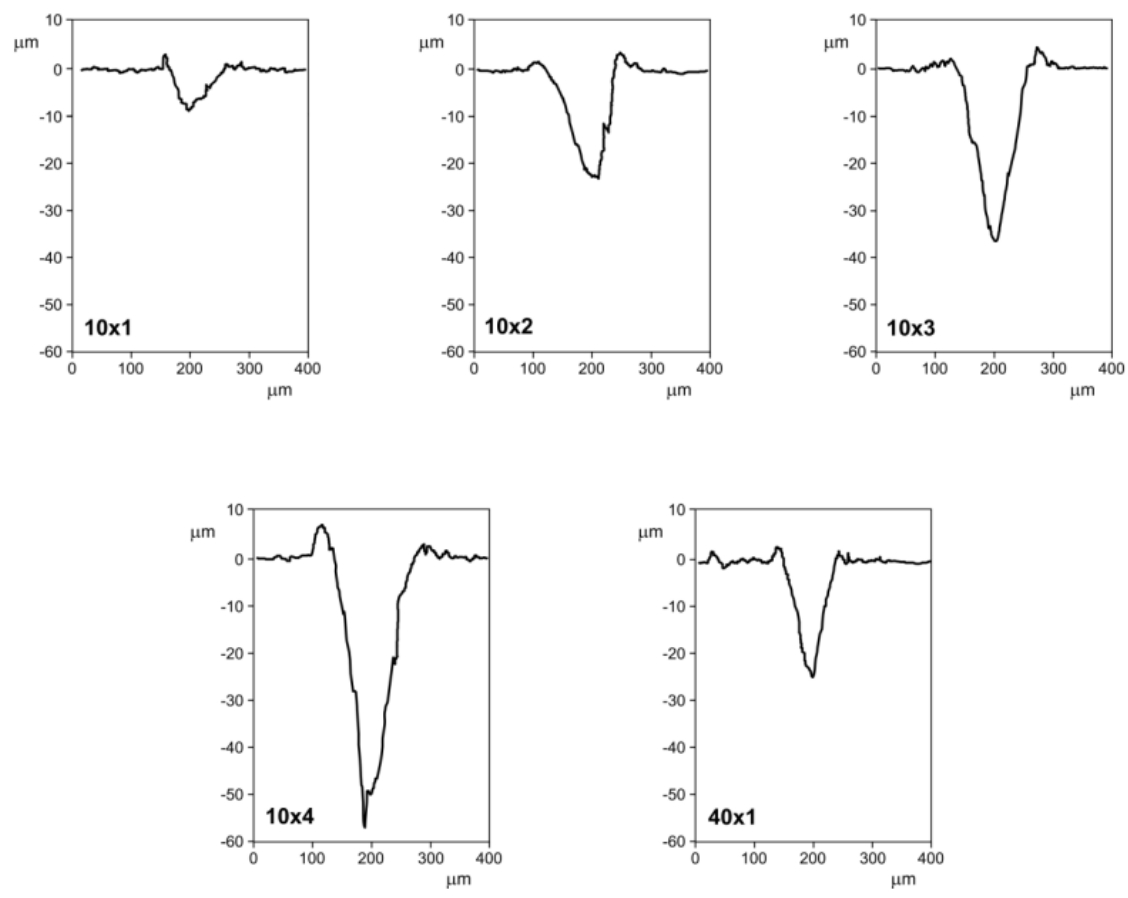

4-2. ábra: Réz mintán készült ablációs kráterek keresztmetszeti fehérfény profilometriás képei. A kráterek különböző impulzusszámú lövésekkel készültek. $A$ képeken látható felirat jelentése: lövésszám x lövésen belüli impulzusszám. 

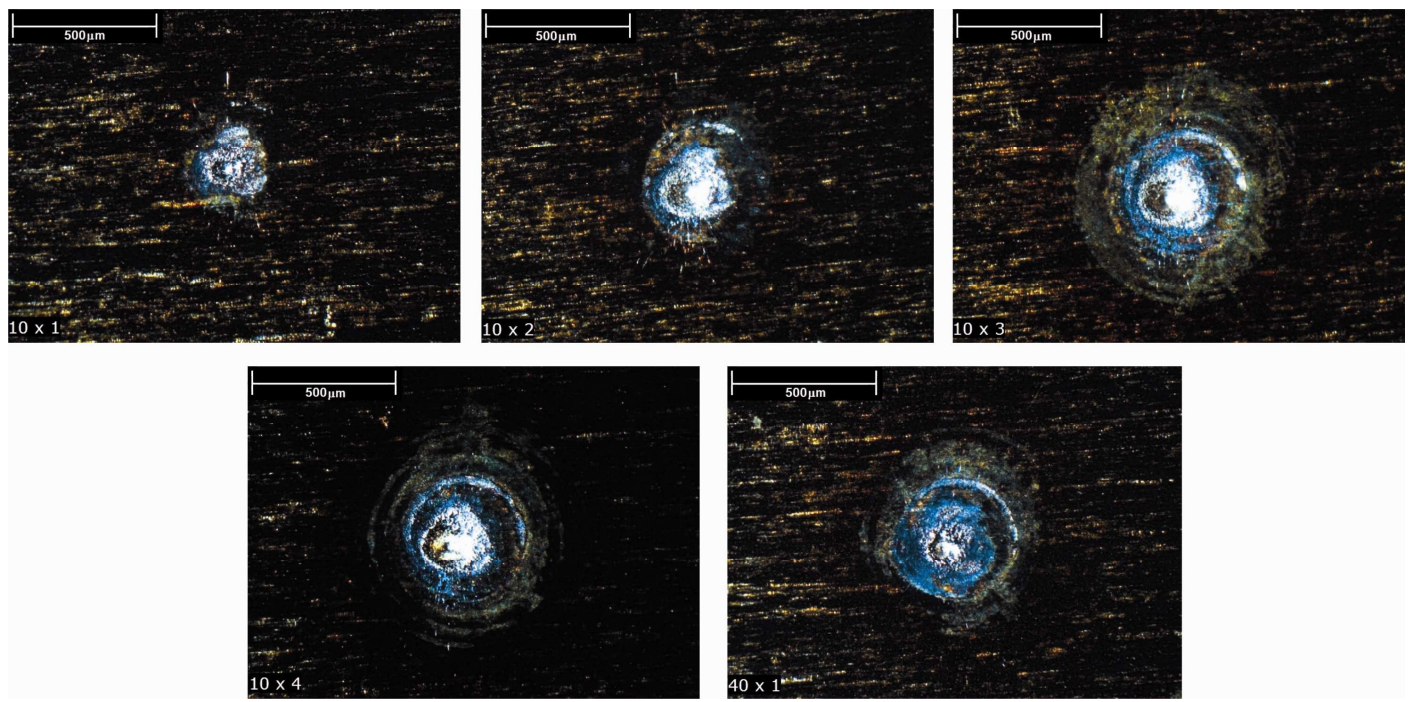

4-3. ábra: Réz mintán készült ablációs kráterek fénymikroszkópos

felvételei. A kráterek különböző impulzusszámú lövésekkel készültek.

A képeken látható felirat jelentése: lövésszám x lövésen belüli impulzusszám.

A profilometriás és mikroszkópos adatok kvantitatív kiértékelése lehetővé tette az ablált anyag mennyiségének közelítő becslését is, amely során a krátereket szabályos, köralapú kúpnak tekintettük, figyelmen kívül hagyva a peremet és a lerakódott törmeléket. A térfogat tömegre való átszámításánál a réz $8,96 \mathrm{~g} / \mathrm{cm}^{3}$ sürüségét használtuk. Az eredményeket a 4-4. ábra mutatja be. Eszerint az ablált anyag mennyisége jelentősen növekszik. Az összehasonlítható esetekben (10x4 és 40x1), ahol az összimpulzusszám, vagyis a befektetett teljes energia megegyezett, az ablált anyagmennyiség kb. hatszorosára emelkedett, ha a lövésen belüli impulzusszámot 1-ről 4-re növeltük. Mindez egyértelműen azt mutatja, hogy a lövésen belüli impulzusok hatása nem független egymástól, hiszen ha az lenne, az ablált anyagmennyiségnek megközelítőleg (a szóráson belül) egyenlőnek kellene lennie. További bizonyíték a lézerenergia mintával való hatékonyabb csatolására a mikroszkópos felvételeken, a kráterek körül látható kör alakú dilatációs redők átmérőjének az impulzusszám növelésével való növekedése. 1-ről 4-re növelve az impulzusszámot ez az átmérő $300 \mu \mathrm{m}$-ről 750 um-re nő. 




Lövésszám $x$ Lövésen belüli impulzusszám

4-4. ábra: A 4-2. ábrán bemutatott kráterek adataiból számított ablált anyag tömege és térfogata.

Megjegyzendő azonban, hogy pl. az „A" rendszerünkben található lézerünk azzal a különleges tulajdonsággal rendelkezik (3.1. fejezet), hogy az impulzuskövetési idő növekszik, ha csökkentjük az impulzusszámot. Az impulzusszám 2-ről 7-re való növe-

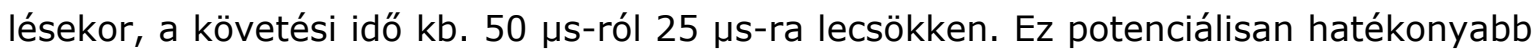
lézer-plazma csatolást eredményezhet és felmerülhet, hogy az impulzusszám növelésével az ablációs mélységben megfigyelt növekedés részben ezen csatolás hatékonyabbá válásának következménye.

Ennek a csatolásnak egyféle módja lehet a sorozaton belüli korábbi impulzusok által okozott lökéshullámfront mögött kialakuló csökkent gáznyomás (pl. [122]), amely a minta soron következő impulzus által való elpárologtatását segíti.

Az ablált anyagmennyiség növekedése részben a minta felmelegedésével is magyarázható lehet. Több ortogonális DP-LIBS tanulmány ugyanis megmutatta [169, 170, 171], hogy az ablált anyagmennyiség valóban jelentősen emelkedik, ha a mintát a plazmakeltést megelőzően kívülről felmelegítik. Egyes tanulmányokban leírt becslések szerint (pl. [122]) a lézerimpulzus beérkezése után a minta felszíni hőmérséklete a kráter környezetében, a minta termikus tulajdonságaitól függően emelkedett lehet, még az impulzus megszúnése után akár $100 \mu$ s-mal később is.

Ezen termikus effektust egy, az egyetemünk Optikai és Kvantumelektronikai Tanszékén Búzás András által kifejlesztett, az abláció termikus hatásait modellező program („T-model”) alkalmazásával mi is tanulmányoztuk. A mintafelszín hőmérsékletének az LIB plazmakeltés során való időbeli és térbeli fejlődését szimuláltuk többfé- 
le fém minta esetében, a hőmérsékleti ciklust fútési és hütési fázisokra osztva. A program a fütési ciklus során kiszámolja a plazmaárnyékolás és a reflexió által okozott veszteség lecsatolása után a bejövő lézerenergia azon részét, amely valójában felelős a minta fütéséért. Ezen számítások során azt az egyszerűsítő feltevést tettük, hogy a felületi fényabszorpció és más anyagi minőségi állandók a hőmérséklettől függetlenek. A kráter "helyén” számított csúcshőmérsékletet ezután betápláltuk a hütési modellbe, amely az energia térbeli és időbeli eloszlását számította háromdimenziós hődiffúziós képletek segítségével. A modell egyes paramétereit tiszta $\mathrm{Cu}$ mintákon, profilometriával mért valódi krátermélységek felhasználásával pontosítottuk. A Tmodell helyességét a Cu mintára számított maximális felületi hőmérséklet adatoknak a Bogaerts és társai által leírt [188], jóval összetettebb, plazmamodellezést is alkalmazó termikus modellje alapján számítható adatokkal való összevetésével ellenőriztük. Azt tapasztaltuk, hogy a hőmérsékleti adatok kiváló egyezést mutatnak $6 \mathrm{GW} / \mathrm{cm}^{2}$ teljesítménysűrűségig, ami nagyságrendileg megfelel a LIBS kísérleteinkben alkalmazott értéknek.

A T-modell alapján tiszta $\mathrm{Cu}, \mathrm{Al}$ és $\mathrm{Zn}$ céltárgyakra is kiszámítottuk a mintafelület maximális hőmérsékletét [168] az impulzuskövetési idő függvényében. Az eredményeket a 4-5. ábra mutatja be.
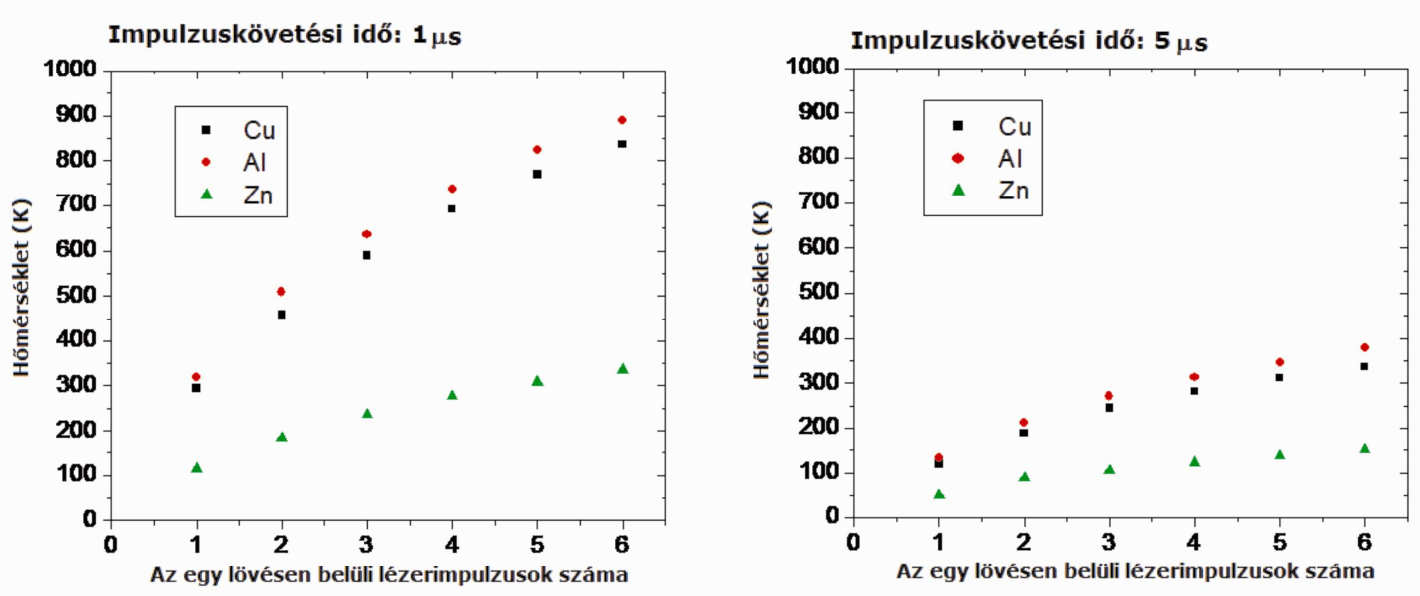

4-5. ábra: A mintafelület maximális hőmérséklete az impulzuskövetési idő és az impulzusszám függvényében [168].

A görbék azt mutatják, hogy 5 s-nál rövidebb impulzuskövetési idők esetén a mintafelület az ablációt/LIB plazmaképződést követően többszáz Kelvinnel magasabb hőmérsékletre hül csak le, mire az impulzussorozatban a következő lézerimpulzus beér- 
kezik. Ez a hőmérsékletemelkedés a három fém közül a $\mathrm{Cu}$ és $\mathrm{Al}$ esetén különösen jelentős.

A fenti, T-modellből számított hőmérséklet adatok pusztán a lézer-anyag kölcsönhatás miatt bekövetkező melegítő hatást veszik figyelembe és nem tartalmazzák azt a fütő hatást, amit a mintafelszín felett, minden egyes impulzust követően néhány tíz $\mu s$-ig jelenlévő, magas hőmérsékletű plazma kifejt. Ez utóbbi hatás a mintafelület lehülését jelentősen tovább lassíthatja.

A kráterek morfológiájával és az ablált anyagmennyiség növekedésével kapcsolatos, ismertetett megfigyeléseink jó egyezést mutatnak más kutatócsoportok legújabb kolineáris DP/MP-LIBS eredményeivel $[117,118,123,125,172]$ és azt mutatják, hogy az egymást gyorsan követő lézerimpulzusok által okozott ablációs folyamatok között erős kölcsönhatás áll fenn. Adataink demonstrálják, hogy ez a hatás jelen van akkor is, ha az impulzuskövetési idő eléri az 50 us-ot. Így az 1.4. fejezetben említett lehetséges mechanizmusok közül, amelyek a jelnövekedést okozhatják az MPLIBS esetében, az eredményeink elsősorban a megnövekedett abláció szerepét támasztják alá közvetlenül.

\subsubsection{A plazma térbeli és időbeli fejlődése}

Az MP-LIB plazmák keltésével kapcsolatban időszakos megfigyelés "extra szikrák" (második, harmadik) megjelenése néhány mm-rel a minta felszíne felett. Egy ilyen esetet mutat be a 4-6. ábra is, amelyet a " $\mathrm{B}$ " rendszerrel rögzítettünk képalkotó üzemmódban és hosszú integrációs idővel (>1 ms). Ebben az esetben egy "extra szikra" volt megfigyelhető a "fo"” plazma felett. Tapasztalataink szerint ez a jelenség gyakori tablettázott vagy szerves minták mérése során, de alkalmanként előfordulnak fémek és félfémek, pl. szilícium esetében is (4-6. ábra).



4-6. ábra: DP-LIB plazmák szilícium minta felett. 
Feltételezésünk szerint ezek individuális levegő/gőz plazmák, amelyeket a többszörös impulzusok okoznak és némi aeroszolt (por, kilökött részecskék, stb.) vagy oxidábilis vegyületeket tartalmaznak. Az általunk használt kis lézerek teljesítménysürüsége nem elég magas ahhoz, hogy a levegőben hozzon létre plazmát, kivéve, ha a küszöbérték aeroszol vagy gőz jelenléte miatt lecsökken. Utóbbi folyamatot elősegíti, hogy a lézerfény fókuszálásához használt mikroszkóp objektíveink relatíve rövid fókusztávolságúak (22 és $48 \mathrm{~mm}$ ), ami azzal jár, hogy a térerősség gradiens nagy a mintafelszín közelében, ahol az előző impulzus által létrehozott ablációból maradó gőz és/vagy részecskék vannak még jelen.

Amennyiben tehát keletkeznek ezek az "extra szikrák" és a detektálás időben és térben integrált (mint a mi LIBS rendszereink esetében), akkor a detektor ezen „szikrák" emisszióját is akkumulálja, ami jelnövekedést okozhat. Ez a mechanizmus úgy is tekinthető, mint egy közbenső folyamat a plazma újrafütése és az ismételt abláció között, mivel a már korábban ablált anyagtól származó emissziót hoz létre. Meg kell még jegyezni, hogy ha jelen vannak ezek az "extra szikrák", azok egymáshoz képest késleltetve keletkeznek, elvben nagyjából követve az impulzusok követési idejét. Ennek eredményeképpen egyes kísérleti körülmények között (gáznyomás, céltárgy minősége, teljesítménysűrűség, stb.) függően a "szikrák" az időben integrált felvételeken átlapolódva jelenhetnek meg, azt a hatást keltve, mintha a plazma hosszan megnyúlna függőleges irányban vagy eltávolodna a mintafelszíntől. Ez megmagyarázhatja az ilyen jellegü morfológiai jellemzéseket leíró tanulmányok megfigyeléseit is $[118,125]$.

Kísérleti rendszereinkkel az MP-LIB plazmákról időfelbontásos felvételeket (térbeli felbontással, de spektrális felbontás nélkül) és emissziós eloszlástérképeket (spektrális és térbeli, de nem időbeli felbontással) is készítettünk.

Az emissziós eloszlástérképek a 4-7. ábrán láthatók, a Si és Mg egy-egy atomilletve ionvonalára, valamint az átlagos háttérre vonatkozóan. A kísérletek során a plazma fényét oldalirányból, egy $200 \mu \mathrm{m}$-es száloptikával gyűjtöttük, amelyet egy 1,5 mm átmérőre kinyitott írisz és egy $10 \mathrm{~cm}$-es lencsetartó („lens tube”) mögött rögzítettünk. Az elrendezés precíz mozgatását egy X-Z mikrométer állvány segítségével végeztük. Hét impulzussal dolgoztunk, az "A" berendezést használva. Amint látható, sem az atom- és ionvonalak, sem a háttér emissziójának térbeli eloszlása nem különbözik jelentősen a rövid fókusztávolságú lencsékkel létrehozott SP-LIB plazmákra tipikusan jellemző gömbi eloszlástól (lásd pl. [45] 2. fejezetében). 

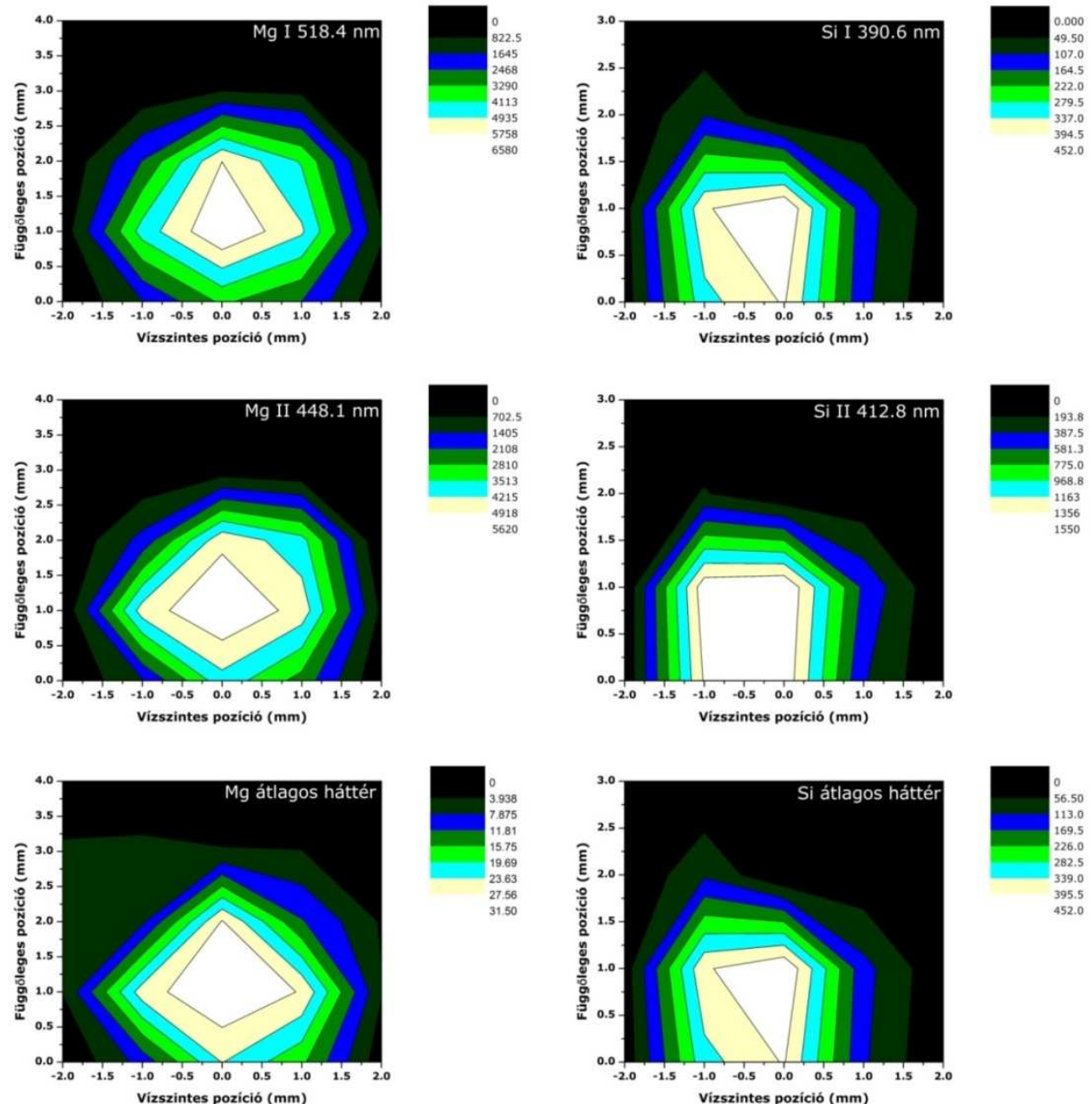

4-7. ábra: Időintegrált, térbeli felbontással, 7 impulzusos lövésekkel készült emissziós eloszlástérképek. A vonalintenzitások háttérkorrigáltak

(integrációs idő: 2 ms, késleltetési idő: 3,4 $\mu \mathrm{s}$ ).

Az időfelbontásos plazmafelvételeket $a$ „B" berendezéssel készítettük. Egy képsorozat készült a plazmáról alumíniumötvözet (SM10) mintán, 3 impulzusos esetben, $2 \mu$ sésletetési idővel és $2 \mu s$-os lépésekkel minden lézerimpulzust követően, $2 \mu$ s-os integrációs idővel. A felvételek a 4-8. ábrán láthatók. Rögtön megállapítható, hogy ebben a kísérletsorozatban nem észleltük „extra szikrák" megjelenését, valamint hogy az impulzussorozaton belül a lézerimpulzusok által keltett plazmák élettartamában, fényességében és térfogatában igen jelentős különbség van. Az első impulzus által létrehozott plazma térfogata a legkisebb és az élettartama is ennek a legrövidebb. Figyelembe véve az első és a második impulzus közötti követési időt ( $8,5 \mu \mathrm{s}, 3-3$. ábra $(B))$, ez a plazma szinte teljesen megszűnik, mire megérkezik a második impulzus. A második és a harmadik impulzus által keltett plazma maximális térfogata és élettartama is jóval nagyobb az elsőnél. A második plazma felfelé irányuló expanziójának lineáris sebessége az első plazmáénak kb. négyszeresére becsülhető. A második és a 
harmadik impulzus közötti követési idő kb. 10,5 s, így ez a plazma még létezik, amikor beérkezik a harmadik impulzus. Ennek hatására a térfogat nem mutat jelentős változást, de az élettartam még tovább nő: a harmadik plazma térfogata $17 \mu \mathrm{s}-$ mal a harmadik impulzus beérkezése után kb. még akkora, mint a második plazma térfogata

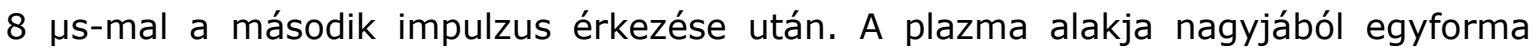
mindhárom esetben: gömb alakú, némi függőleges irányú megnyúlással. A plazma középpontjának magassága valamelyest nő ( $\approx 1 \mathrm{~mm}$-ről $\approx 1,5 \mathrm{~mm}$-re), azonban ha figyelembe vesszük az össztérfogat szignifikáns növekedését, ez már nem tűnik jelentős változásnak. Hasonló megfigyeléseket tettek más kutatócsoportok is DP-LIB plazmák tanulmányozásakor [117, 118, 121, 123].
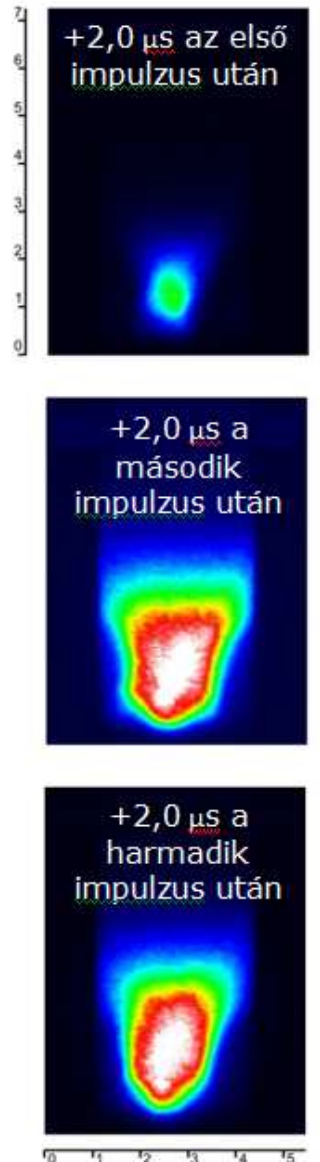
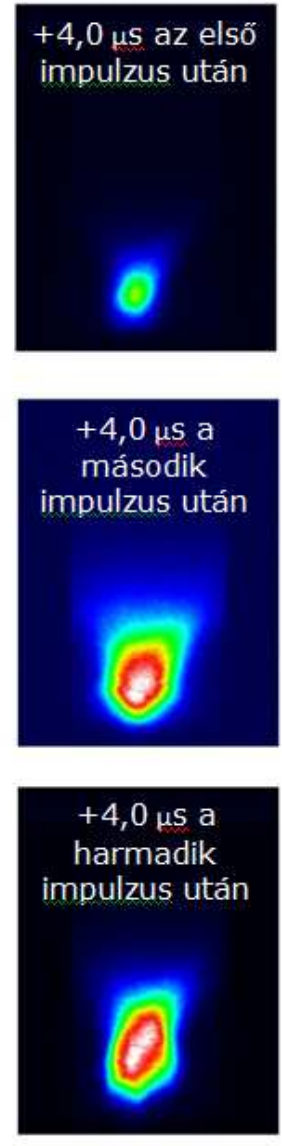
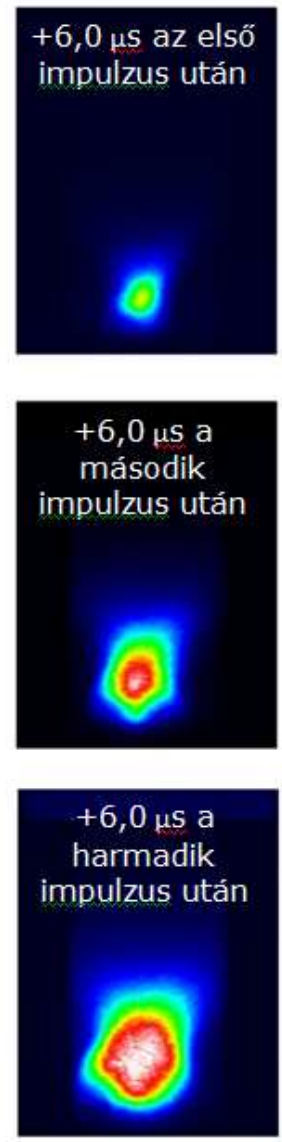
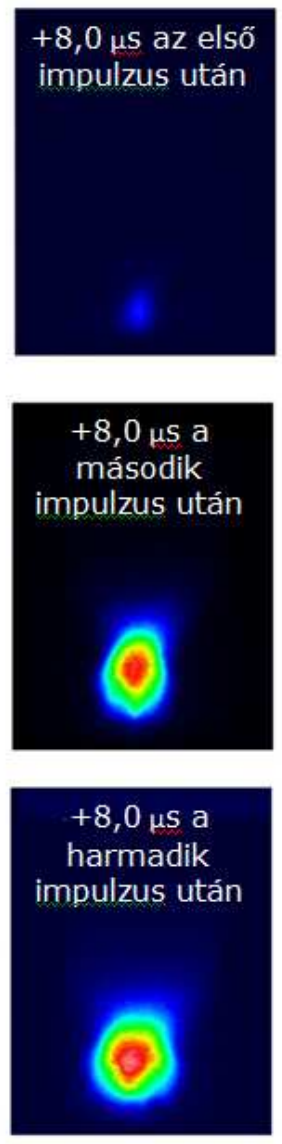
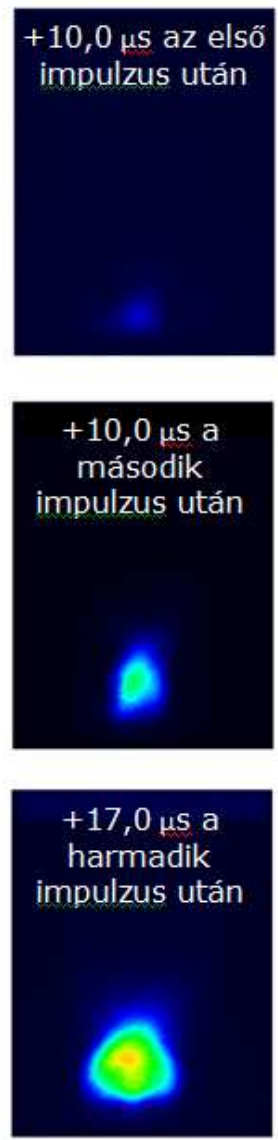

4-8. ábra: Alumínium ötvözeten, 3 impulzussal létrehozott plazma időfelbontásos képei. A skála egysége mm. A színskála mesterséges: a legnagyobb intenzitású területek fehérek, a legkisebbek feketék.

Ugyanakkor azt tapasztaltuk, hogy az általunk használt berendezésekkel létrehozott MP-LIB plazmák morfológiája hasonló az SP-LIB plazmákéhoz, az időbeli fejlődésük azonban nagyon eltérő. A plazmák kiterjedési sebessége, fényessége, maximális 
térfogata és az emisszió élettartama nagyobb az impulzussorozaton belül később érkező impulzusok esetében. Az irodalomban elterjedt egyik magyarázat erre a jelenségre, hogy a második impulzus által létrehozott plazma csökkent nyomású atmoszférában terjed ki. Bár ez a hatás az MP-LIBS abláció során is fontos szerepet játszik, nem szolgál magyarázattal arra, miért különböző a jelenség a harmadik, negyedik, stb. impulzust követően; ezen plazmák viselkedésének meglehetősen hasonlónak kellene lennie a második impulzus által keltett plazmáéhoz. Az ismételt/megnövekedett ablációra szolgáló bizonyíték a nagyobb ablációs rátára vonatkozó adatokból származik és azt Bogaerts és társainak a későbbi lézerimpulzustól származó kisebb mértékű plazmaárnyékolást felhasználó szimulációs számításai is alátámasztják [173]. Megítélésünk szerint esetünkben a folyamatok még összetettebbek és a lézerimpulzusok ablált anyaggal (részecskék, gőzök) való kölcsönhatása sem zárható ki.

\subsubsection{A plazmahőmérséklet}

Annak érdekében, hogy az impulzussorozaton belül a lézer-plazma kölcsönhatás relevanciáját tanulmányozzuk, meghatároztuk a gerjesztési hőmérsékletet is az egyes impulzusok keltette plazmákban. Az irodalomban általánosan elterjedt nézőponthoz igazodva lokális termodinamikai egyensúlyt (LTE) feltételeztünk és a Saha-Boltzmann módszert alkalmaztuk. LTE-ben a gerjesztési, az ionizációs és a kinetikus hőmérséklet is megegyezik, ezért a számított hőmérséklet nevezhető "plazmahőmérséklet"-nek. Magnézium ionvonalak (279,08 nm; 279,55 nm; 279,80 nm) intenzitás adatait használtuk fel a plazmahőmérséklet számítása során. A mérés egy alumíniumötvözet mintán (SM10) történt $\mathrm{a}$ „ $\mathrm{B}$ ” rendszerrel, négyimpulzusos sorozatokkal dolgozva. A vonalintenzitás adatokat az egyes lézerimpulzusok beérkezésétől számított 500 ns és 1500 ns késleltetési időknél és 500 ns integrációs idővel rögzítettük, a plazma legnagyobb fényességű területéről, így a számított plazmahőmérsékletek is ezekre az időtartamokra és zónákra vonatkoznak.

A 4-9. ábrán látható, hogy 500 ns késleltetési időnél a második impulzus hatására a hőmérséklet $20000 \mathrm{~K}$-ről $25000 \mathrm{~K}$-re emelkedett és bár az a további impulzusok hatására is mutatott némi növekedést, de nem olyan szignifikánsat, mint a második lézerimpulzus esetében. A hőmérséklet 1500 ns késleltetési időnél jelentősen alacsonyabb. Plazmahőmérséklet növekedés gyakorlatilag itt is csak a második impulzus hatására következik be (16 000 K-ről 19000 K-re), a hőmérséklet a további impulzusok hatására alig változik. Az eredmények alapján elmondható, hogy a második impulzus jelentős növekedést okoz a plazmahőmérsékletben, míg a további impulzusokra ez már nem érvényes. Eddigi adataink tehát azt bizonyítják, hogy ha történik plazma- 
újramelegítés, az az ablációs eseményektől nem független és hatása viszonylag csekély.

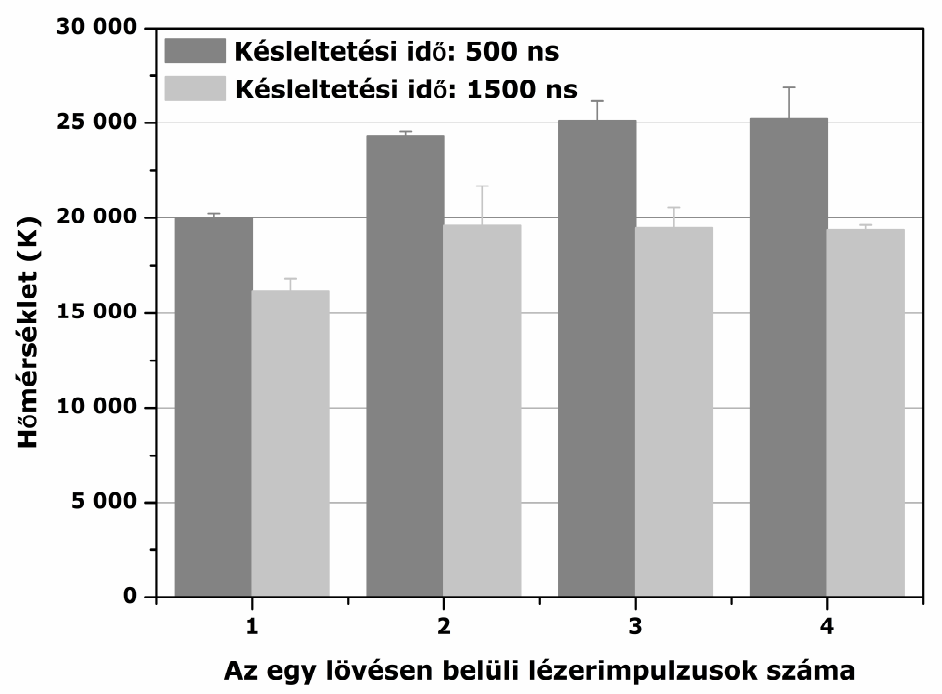

4-9. ábra: A hőmérséklet változása az impulzusszám függvényében, 500 ns és 1500 ns késletetési időnél, alumínium ötvözetmintán létrehozott plazmában $\mathrm{Mg}$ ionvonalra.

A hibasávok 5 ismételt mérésből adódó szórásadatok.

Fontosnak tartjuk megjegyezni, hogy a DP-LIBS [109, 117, 123, 174] és MPLIBS [125] kéziratokban közölt plazmahőmérséklet értékek erősen szórnak (8 $000 \mathrm{~K}$ től 25000 K-ig szinte minden értékkel találkozni lehet). Nagyjából általános megfigyelés, hogy a részecskék plazmában való inhomogén eloszlásának következtében az ionvonalak alapján számított hőmérséklet általában magasabb az atomvonalak alapján számítottnál; a plazma belső, melegebb magja több iont produkál [175]. Vannak tanulmányok, amelyek hozzánk hasonlóan a második impulzus hatására bekövetkező jelentős hőmérséklet emelkedésről számoltak be [109, 118, 174], mások éppen az ellenkezőjét figyelték meg $[117,176]$ és vannak, akik szerint a reláció függ az impulzuskövetési időtől is $[125,173]$. Ezek az eltérő tartalmú megfigyelések a műszerek optikai összeállítása és a céltárgy anyagi minősége között fennálló különbségekkel, valamint az LTE kondíció hasznos, de kérdéses érvényű feltételezésével magyarázhatók. 


\subsubsection{Az emissziós jel késleltetési időtől való függése}

Számos elem ( $\mathrm{pl}$. Si , Al, Zn, Cu, tiszta fémek) atom- és ionvonalainak, valamint az átlagos háttérnek a térben integrált nettó intenzitását tanulmányoztuk a késleltetési idő függvényében, háromimpulzusos esetben. A mérések az " $A$ " rendszerrel készültek, 2 ms integrációs idő mellett. Egy Cu és Zn atomvonalra, valamint a Zn vonal körüli átlagos háttérre kapott időfüggő intenzitás adatok láthatók a 4-10 ábrán. Ezek a görbék kutatócsoportunk egyik korábbi közleményében Al specieszekre közölt görbékhez hasonlóan, lefutásuk alapján két csoportba sorolhatók.

Néhány spektrumvonal (pl. Zn (I) 636,2 nm vagy Al (II) 559,3nm) emissziója a késletetési idő növekedésével lépcsőzetes lefutást mutat és a lépcsők időbeli pozíciója megfelel az impulzusok követési idejének (4-10. ábra (A) és 3-3. ábra (A)). Amint a késleltetési idő eléri az impulzuskövetési idő értékét, az emissziós jel hirtelen lecsökken és gyakorlatilag konstans marad a következő lézerimpulzus megérkezéséig (valójában a késletetési idő növekedése egyre több impulzus hatását "zárja ki" az emissziós megfigyelésből, integrációból). Ez a megfigyelés azt jelenti, hogy ezek a spektrumvonalak gyakorlatilag minden egyes lézerimpulzustól önálló gerjesztést szenvednek; ez megmutatható az intenzitásgörbe numerikus deriválásával is, ami csúcsokat eredményez az impulzuskövetési időknek megfelelő pozíciókban. A 4-10. ábra (B) is, amely az átlagos háttér lépcsőzetes viselkedését mutatja, alátámasztja a plazma megújulását (vagy a "breakdown” ismétlődését). Azok a spektrumvonalak, amelyekre ezt a megfigyelést tettük magas, 7 eV-ot meghaladó energiaszintektől induló elektronátmenettől származnak (Al (II) 559,3 nm: 15,47 eV és Zn (I) 636,2nm: 7,74 eV). Viselkedésük azt sugallja, hogy ezen részecskékre a plazmában lévő gerjesztési körülmények csak rövid ideig kedvezőek, amíg a plazma hőmérséklete magas.

Más, főként atomvonalak (Al (I) 309,3 nm és Cu (I) 309,4 nm) esetében eltérő viselkedést tapasztaltunk: ezt láthatjuk a 4-10. (C) ábrán. Ezek a vonalak az impulzussorozat teljes időtartama alatt (kb. $100 \mu \mathrm{s}-\mathrm{ig}$ ) folyamatos gerjesztést szenvednek és emissziójuk csak ezután kezd el nagyon lassan csökkenni. Erre magyarázattal szolgálhat relatíve alacsony gerjesztési energiájuk (Al (I) 309,3 nm: 4,02 eV és Cu (I) 309,4 nm: 5,39 eV) és az MP-LIB plazmákban uralkodó kisnyomású gerjesztési környezet. Ezzel kapcsolatban utalunk Matsuta és Wagatsuma alacsony nyomású SP-LIB plazmák emissziós jellemzőit vizsgáló tanulmányaira [177-179]. A kutatók úgy tapasztalták, hogy kb. 100 Torr nyomású gázatmoszférában (ami hasonló a Cristoforetti és társai becslése szerint, a DP-LIBS első impulzusa által létrehozott lökéshullámfront mögötti, a mintafelszín közelében uralkodó nyomásértékhez [172]) több atom- és ionvonal késleltetett és hosszantartó emissziót mutatott. 

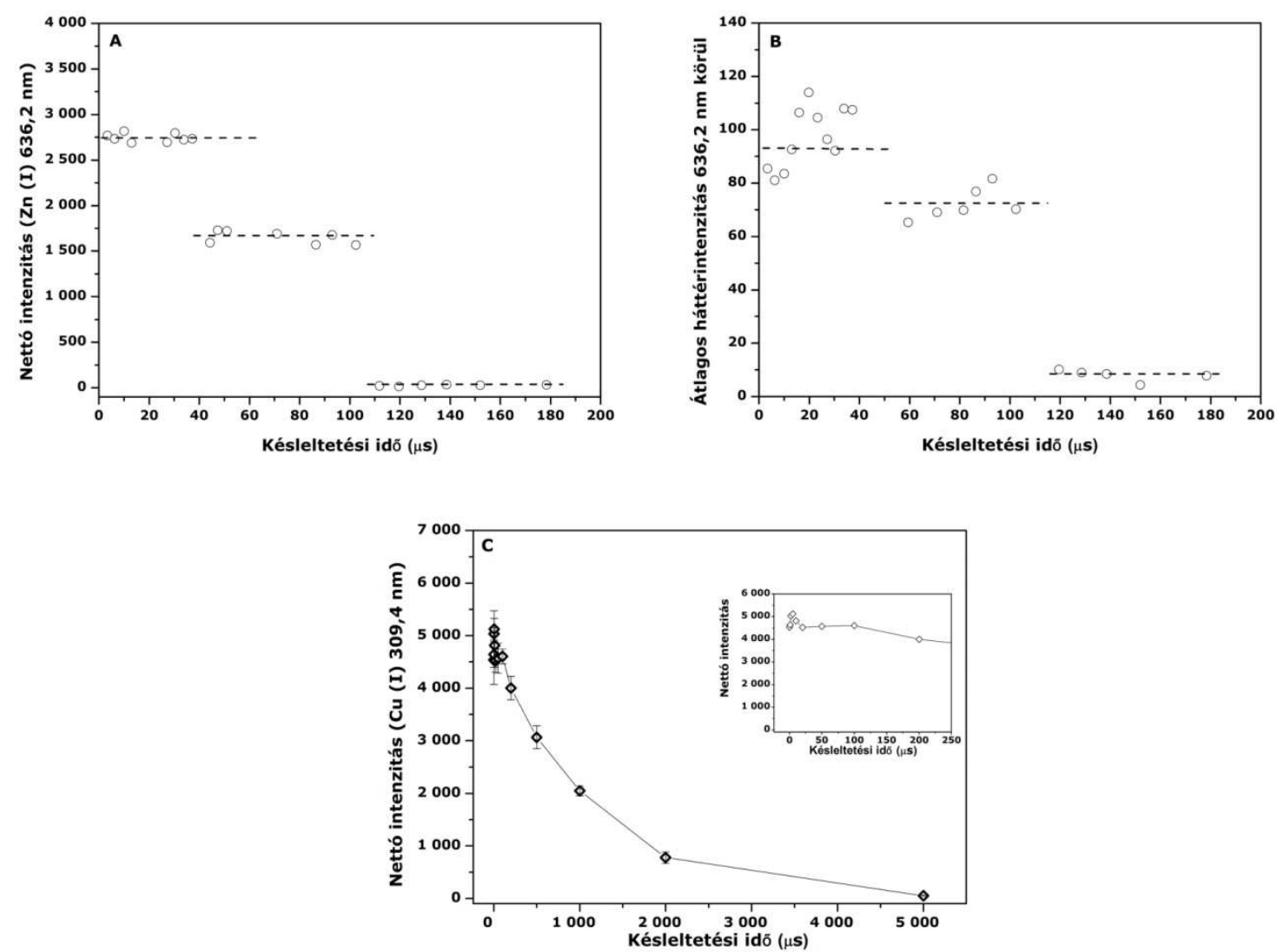

4-10. ábra: Háromimpulzusos lövésekkel kapott emissziós jel a késletetési idő függvényében (A) Zn (I) 636,2 nm, (B) átlagos háttérintenzitás a cink vonal körül és (C) Cu (I) 309,4 nm.

Így például a Cu (I) 324,8 nm-es vonalán az emisszió jelentős, mintegy 8,9 $\mu$ s időbeli késéssel (a lézerimpulzushoz képest) jelent meg és az több mint $20 \mu \mathrm{s}$-ig tartott. A jelenséget a szerzők azzal magyarázták, hogy a csökkent nyomás miatt gyorsan táguló plazmában a mintából és a környezetből származó atomok megnövekedett sebessége miatt nagyobb az ütközéses gerjesztés lehetősége. Tognoni és társai is hosszan-


son, $10 \mu \mathrm{s}$-ig tartó impulzuskövetési idő és DP-LIBS elrendezés mellett [180]. Mivel a fent leírt körülmények hasonlóságot mutatnak a mi MP-LIBS kísérleti körülményeinkkel, feltételezhető, hogy az általunk megfigyelt hosszantartó emisszió is az ütközéses gerjesztések következménye, amelyeknek kedvez az impulzussorozaton belüli korábbi impulzusok által okozott csökkent nyomású környezet. 


\subsection{5. Összefoglalás}

A DP-LIBS irodalomban az SP-LIBS-hez képest tapasztalt, a plazma- és emissziós jellemzők megfigyelt változásainak okaira vonatkozó felvetések (1.4. fejezet) három csoportba, a lézer-minta, a lézer-plazma és a lézer-aeroszol kölcsönhatások csoportjába sorolhatók. A jelen fejezetben bemutatott kísérleteink révén elsőként tettünk kísérletet ezen összetett folyamatoknak a kolineáris, térbeli és időbeli integrálást alkalmazó MP-LIBS esetben játszott szerepének tisztázására.

Kísérleti adataink azt mutatják, hogy a $\mu$ s időskálába eső impulzuskövetési idők esetén a kolineáris MP-LIBS során az egyes lézerimpulzusok okozta események között erős kölcsönhatás van és általában a lézer-minta egymásra hatás dominál. A követő impulzusok hatására mindig bekövetkezik abláció és plazmaképződés. A mintafelület előkondicionálódásának fontos szerepére utal, hogy az impulzussorozat által ablált anyagmennyiség igen jelentősen nő a lézer lövésen belüli impulzusok számával, miközben a plazmahőmérséklet a második impulzustól kezdődően közel állandó. A lézerminta kölcsönhatások közül a mintafelület előfütésének hatását kiemelten tanulmányoztuk modellezés segítségével és megállapítottuk, hogy az jelentősen hozzájárulhat a megnövekedett ablációhoz. Ugyanakkor a plazma specieszek újragerjesztődésére utaló kísérleti bizonyítékokat is találtunk (pl. egyes kisebb gerjesztési energiájú speciszek elnyújtott, az impulzussorozat időtartama alatt mutatott közel konstans emissziója), ezért ennek az effektusnak a hozzájárulása sem elenyésző pl. a térben és időben integrált emissziós jelek javulásának kialakulásához. 


\subsection{Az analitikai teljesítőképesség jellemzése}

A többszörös lézerimpulzusokkal történő gerjesztés hatására a fontosabb teljesítményjellemzőkben ( $p l$. érzékenység, ismételhetőség) bekövetkező, reprodukálhatóan tapasztalt javulás arra inspirált minket, hogy munkánk következő lépése az MPLIBS módszer analitikai teljesítőképességének részletes és szisztematikus vizsgálata legyen. Ezeket a vizsgálatokat 11 elem több mint 20 spektrumvonalának számos mintamátrixban való tanulmányozása révén végeztük el. Eredményeinket a következő alfejezetek ismertetik.

\subsubsection{Az emissziós jel viselkedése}

Nettó jelnövekedés

A nettó és az impulzusszámmal (energiával) normalizált nettó jelintenzitás változását vizsgáltuk az egy lövésen belüli impulzusszám függvényében fém, polimer és grafit mintákon. A számos elem atom- és ionvonalára vonatkozó adatokat mutatja be a 4-11. és 4-12. ábra. Az atomvonalak esetében (4-11. ábra) egyértelmúen megállapítható, hogy mind a nettó, mind az energiával normalizált nettó intenzitás növekszik az impulzusszám növelésével és ez a növekedés a nettó intenzitásoknál gyorsabb a lineárisnál. A normalizált görbék növekedése azt mutatja, hogy többimpulzusos esetben minden egyes impulzus által előidézett nettó jel nagyobb az előző impulzustól származó jelnél. Ha nem így lenne, akkor közel nulla meredekségű görbét kapnánk. Ebből következik, hogy a lézerimpulzusok hatása nem független egymástól.

Az ionvonalak vizsgálata során eltérő viselkedést tapasztaltunk (4-12. ábra). Némely vonalak (pl. a Mg (II) 448,1 nm és a Si (II) 412,8 nm) hasonlóan viselkedtek, mint az atomvonalak, vagyis erőteljes növekedés figyelhető meg mind a nettó, mind a normalizált nettó intenzitásukban az impulzusszám függvényében. Más ionvonalaknál (pl. Au (II) $312,7 \mathrm{~nm}$ és Al (II) 422,7nm) bár a nettó intenzitás szintén monoton nő az impulzusszám függvényében, a normalizált intenzitásgörbék gyakorlatilag nem mutatnak növekedést az impulzusszám növelésével. Ez azt jelenti, hogy ezeknél a magas gerjesztési energiával rendelkező vonalaknál minden egyes lézerimpulzus hasonló vagy csak kismértékben növekvő jelintenzitást produkál. Fontos ugyanakkor megjegyezni, hogy analitikai szempontból nem a normalizált, hanem a nettó jelnek van jelentősége. 

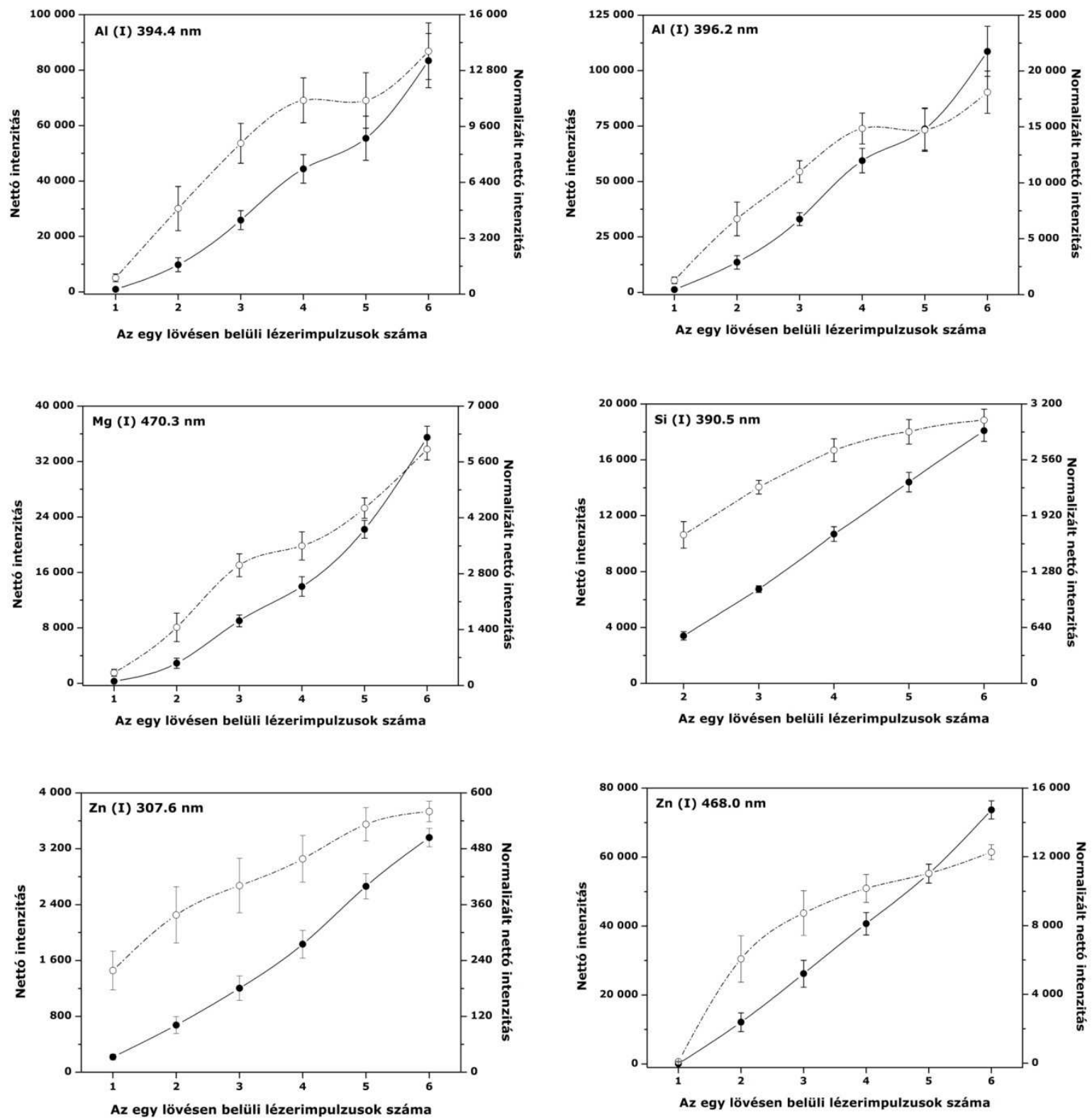

4-11. ábra: A nettó ( $)$ és az energiával normalizált nettó $(O)$ emissziós intenzitások néhány vizsgált atomvonalra az egy lövésen belüli impulzusszám függvényében.

A hibasávok 24, illetve 25 összimpulzusszámból adódó szórást jelölik (4.2.2. fejezet). 



4-12. ábra: A nettó $(\bullet)$ és az energiával normalizált nettó $(\bigcirc)$ emissziós intenzitások néhány vizsgált ionvonalra az egy lövésen belüli impulzusszám függvényében.

A hibasávok 24, illetve 25 összimpulzusszámból adódó szórást jelölik (4.2.2. fejezet).

Gautier és társai egy nemrégen megjelent tanulmányukban leírják, hogy megfigyeléseik szerint DP-LIBS-ben a gerjesztési energia ( $E_{g}$, ionvonalakra az ionizációs és a gerjesztési energia összegeként számítva) korrelációban van a jelnövekedéssel, továbbá ez a hatás az impulzusok közötti késleltetési idő növekedésével egyre hangsúlyosabbá válik [181]. Ez alapján esetünkben, ahol a késleltetési idő viszonylag hosszú (kb. min. $25 \mu \mathrm{s}$ ), a jelnövekedésnek az ionvonalak és a nagy $E_{g}$-vel rendelkező atomvonalak esetében kellene a legnagyobbnak lennie. Saját jelenlegi és korábbi [35, 37, 129] eredményeink nem támasztják azonban alá ennek az összefüggésnek a meglétét. Ezt illusztrálja a 4-13. ábra is, amely grafikusan ábrázolja a spektrumvonalak gerjesztési energiájának függvényében a nettó jelnövekedést (1-ről 6-ra növelve az impulzusszámot). Gautier-ék eredményeivel ellentétben azt tapasztaltuk, hogy a jelnövekedés az alacsonyabb gerjesztési energiával ( $\left.E_{g} \leq k b .7 e v\right)$ bíró vonalak esetében a legnagyobb. A 4.1. fejezetben leírt megfigyeléseink szerint ezeknél a "soft" spektrumvonalaknál az MP-LIBS feltételek időben elnyúló gerjesztést tesznek lehetővé, amely jelentősen hosszabb idejű emisszióhoz vezet. Másrészről, a magas $\mathrm{E}_{\mathrm{g}}$-vel ren- 
delkező spektrumvonalakon a gerjesztés rövid idejü és minden egyes újabb impulzus hatására megújul. A 4-13. grafikon alapján megállapítható, hogy az impulzusszámot hatra növelve a nettó jelnövekedés nagyobb az alacsony gerjesztési energiák esetében. A maximális jelnövekedés az 5-7 eV-tal rendelkező vonalaknál volt tapasztalható. Érdemes azt is megjegyezni, hogy az időintegrált detektálás (2 ms) miatt a magas gerjesztési energiájú ionvonalak is mutatnak intenzitásnövekedést.

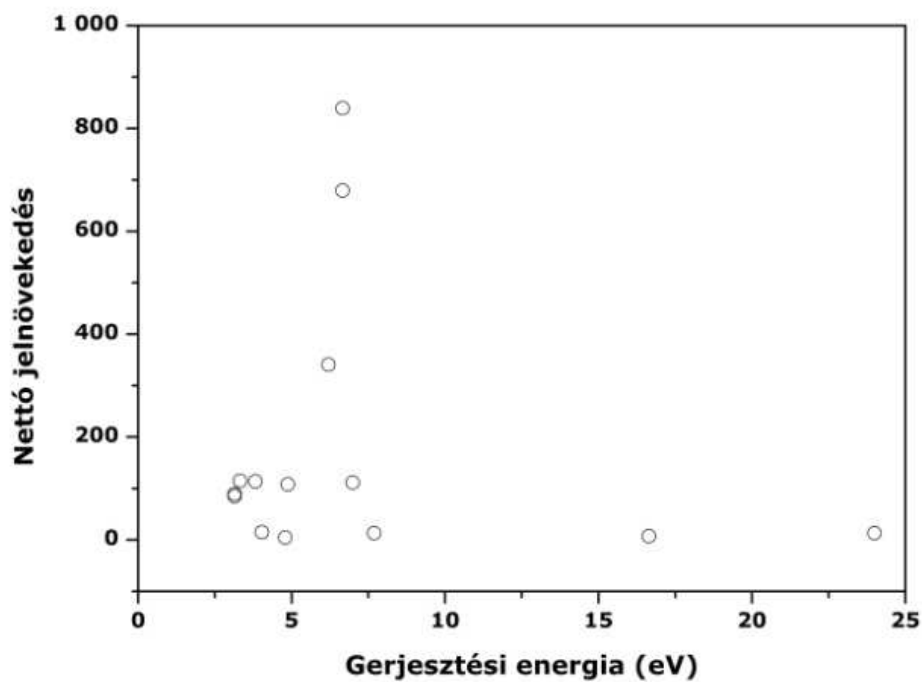

4-13. ábra: A nettó jelnövekedés hat impulzus esetén, az összes vizsgált spektrumvonalra a gerjesztési energia függvényében. A jelnövekedés számításánál az egy impulzussal kapott jel volt a referencia.

A 4-1. táblázat összefoglalja az összes vizsgált spektrumvonalra a nettó és a normalizált nettó jelnövekedést az egy impulzussal történt mérésekhez viszonyítva. Látható, hogy az analitikai szempontból fontosabb nettó jelnövekedés minden esetben szignifikáns, sőt egyes esetekben a többszázszoros értéket is eléri. Hangsúlyozni kell azonban, hogy az aktuális jelnövekedés erősen függ az optikai elrendezéstől és az adatgyűjtés módjától, így az értékek közvetlenül nem hasonlíthatók össze más kutatók által publikált eredményekkel (amelyek azonban hasonló nagyságrendű javulásról számolnak be). Az okokkal kapcsolatban, amelyeket több tanulmány is részletesen tárgyal [182, 183], szeretnénk rámutatni arra a tényre, hogy az oldalirányú, két gyűjtőlencsés elrendezés, amelyet sok LIBS berendezésben használnak, analitikai szempontból nem optimális a DP- és MP-LIBS mérések során, mivel így a plazmának csak egy kis részéből gyűjthető a fény. A DP- és MP-LIB plazmák esetében, amelyek sokkal gyorsabban tágulnak és nagyobb térfogatot érnek el, mint az SP-LIB plazmák, az 
egyetlen lencsével vagy lencse nélkül történő térbeli integráció sokkal alkalmasabb a jelnövekedés kihasználásához.

\begin{tabular}{|c|c|c|c|c|c|c|c|}
\hline \multirow{3}{*}{ Mátrix } & \multirow{3}{*}{ Speciesz } & \multirow{3}{*}{$\lambda(\mathbf{n m})$} & \multirow{3}{*}{$\begin{array}{l}E_{\text {gerj }} \\
(\mathrm{eV})\end{array}$} & \multicolumn{4}{|c|}{ Jelnövekedés } \\
\hline & & & & \multicolumn{2}{|c|}{ Nettó jel } & \multicolumn{2}{|c|}{$\begin{array}{c}\text { Normalizált nettó } \\
\text { jel }\end{array}$} \\
\hline & & & & 2 imp. & 6 imp. & 2 imp. & 6 imp. \\
\hline \multirow{19}{*}{ 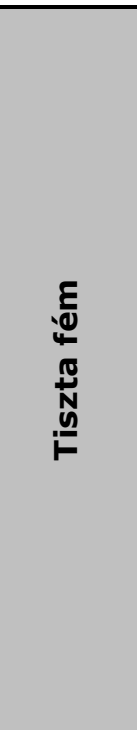 } & Al I & 394,4 & 3,14 & 10,5 & 89,3 & 5,2 & 14,9 \\
\hline & Al I & 396,2 & 3,14 & 10,6 & 85,1 & 5,3 & 14,2 \\
\hline & Al II & 422,7 & 23,99 & 2,1 & 13,2 & 1,1 & 2,2 \\
\hline & $\mathrm{Au} \mathrm{I}$ & 291,5 & - & 3,6 & 13,3 & 1,8 & 2,2 \\
\hline & Au II & 312,7 & - & 2,7 & 8,2 & 1,4 & 1,4 \\
\hline & C I & 247,8 & 7,69 & 2,2 & 13,3 & 1,1 & 2,2 \\
\hline & $\mathrm{Cr} \mathrm{I}$ & 520,8 & 3,32 & 10,4 & 115,1 & 5,2 & 19,2 \\
\hline & Cu I & 510,5 & 3,82 & 12,1 & 114,1 & 6,1 & 19,0 \\
\hline & $\mathrm{Cu} \mathrm{I}$ & 521,8 & 6,20 & 30,1 & 341,1 & 15,0 & 56,9 \\
\hline & $\mathrm{Cu}$ II & 203,7 & 16,64 & 2,3 & 7,4 & 1,2 & 1,2 \\
\hline & $\mathrm{Mg} \mathrm{I}$ & 470,3 & 6,99 & 9,2 & 111,7 & 4,6 & 18,6 \\
\hline & Mg II & 448,1 & 19,28 & $1,0 *$ & $10,4 *$ & $1,0 *$ & $3,5 *$ \\
\hline & Si I & 390,5 & 5,08 & $1,0 *$ & $5,3 *$ & $1,0 *$ & $1,8^{*}$ \\
\hline & Si II & 412,8 & 21,00 & $1,0 *$ & $6,6 *$ & $1,0 *$ & $2,2 *$ \\
\hline & Sn I & 270,7 & 4,79 & 2,2 & 5,0 & 1,1 & 0,8 \\
\hline & Sn I & 452,5 & 4,87 & 10,8 & 108,2 & 5,4 & 18,0 \\
\hline & $\mathrm{Zn} \mathrm{I}$ & 468,0 & 6,66 & 138,1 & 839,2 & 69,1 & 139,9 \\
\hline & Zn I & 481,0 & 6,66 & 94,8 & 679,3 & 47,4 & 113,2 \\
\hline & Zn I & 307,6 & 4,03 & 3,1 & 15,4 & 1,5 & 2,6 \\
\hline \multirow{3}{*}{ Acél } & $\mathrm{Cr} \mathrm{I}$ & 520,8 & 3,32 & 1,6 & 27,5 & 0,8 & 4,6 \\
\hline & Fe I & 414,4 & 4,55 & 3,0 & 48,1 & 1,5 & 8,0 \\
\hline & Au I & 291,5 & - & 2,4 & 6,5 & 1,2 & 1,1 \\
\hline \multirow{6}{*}{$\begin{array}{l}\stackrel{ \pm}{N} \\
: 0 \\
: 0 \\
: 0\end{array}$} & Cu I & 510,5 & 3,82 & 12,5 & 67,8 & 6,3 & 11,3 \\
\hline & Cu I & 521,8 & 6,20 & 26,7 & 171,6 & 13,4 & 28,6 \\
\hline & Cu II & 203,7 & 16,64 & 2,6 & 7,3 & 1,3 & 1,2 \\
\hline & Sn I & 270,7 & 4,79 & 1,9 & 5,6 & 0,9 & 0,9 \\
\hline & Sn I & 452,5 & 4,87 & 8,6 & 99.0 & 4,3 & 16,5 \\
\hline & Zn I & 481,0 & 6,66 & 76,8 & 572,4 & 38,4 & 95,4 \\
\hline PTFE & C I & 247,8 & 7,69 & 2,0 & 5,8 & 1,0 & 1,0 \\
\hline
\end{tabular}

4-1. táblázat: A kísérletsorozatban vizsgált spektrumvonalak hullámhossza, gerjesztési energiája, valamint a nettó jelnövekedés, ha egy helyett kettő és egy helyett hat impulzust használunk. A hiányzó $E_{g}$ adatok egyik általunk felhasznált adatbázisban sem voltak megtalálhatók. A*-gal jelölt esetekben az egy impulzussal kapott jel túl gyenge volt, ezért a kétimpulzusos jelet használtuk referenciaként.

\section{A háttérjel}

Az eddig bemutatott eredmények mindegyike háttérkorrigált nettó intenzitásadatokból származik, azonban szükségesnek tartottuk megvizsgálni a többszörös impulzusok és az időintegrációs detektálás háttérjelre gyakorolt hatását is, hiszen ha az egymást követő impulzusok mindegyike növeli a hátteret, ez az időintegrációs detektálás következtében akkumulálódik a spektrumban. A 4-14. ábra mutatja az átlagos háttérjel viselkedését az impulzusszám függvényében néhány atom- és ionvonal szomszédságában az UV és a Vis tartományokban. Látható, hogy az átlagos háttérintenzitás csak csekély mértékben növekszik az impulzusszám növelésével, és a norma- 
lizált görbe gyakorlatilag konstans vagy telítési jelleget mutat. Ez azt jelenti, hogy az egyes impulzusok által generált háttér rövid élettartamú és hozzájárulása a második impulzustól kezdve ugyanaz. Az első impulzus hozzájárulása kisebb a többiénél, ami a 3,4 us késleltetési idő használatából adódik, mivel ennyi idő elteltével a plazma hőmérséklete már alacsony és a belőle származó folytonos emisszió is lecsökken [37]. Ezek a megfigyelések tehát azt mutatják, hogy az általunk alkalmazott hosszú (2 ms) integrációs idő jelentősen nem rontja a jel/zaj viszonyt.


4-14. ábra: $A$ háttérjel $(\bullet)$ és az energiával normalizált háttérjel $(O)$ néhány vizsgált spektrumvonalra az egy lövésen belüli impulzusszám függvényében.

A háttérjel számítása a spektrumvonalak két oldalán, néhány nm-es tartomány átlagolásával történt.

\section{Mátrixhatás}

Mint minden szilárdmintás módszernél, így a LIBS-nél is számolni kell a mátrixhatással (1.3. fejezet). Röviden ezért mi is tanulmányoztuk a mátrix hatását az emiszsziós jelintenzitásra, illetve a jelnövekedésre. A 4-15. (A) és (B) ábrán láthatjuk a nettó jel viselkedését egy réz, egy arany, egy króm és egy szén vonalon tiszta elemi formájú minta esetén, valamint ugyanezen spektrumvonalak viselkedését eltérő mátrix- 
ban (ötvözet vagy polimer). A nettó jelnövekedés hat impulzus esetében tiszta állapotban és többkomponensü mátrixban rendre kb. 13,3 és 6,5 az Au (I) vonalra; 341 és 171 a Cu (I) vonalra; 7,4 és 7,2 a Cu (II) vonalra; 2,2 és 1,0 a C (I) vonalra; 6,8 és 4,3 a Cr (I) vonalra. A görbék lefutása hasonló a két mátrixban, ami azt sugallja, hogy az elektronszerkezet jobban befolyásolja a jelnövekedést, mint a mátrix.
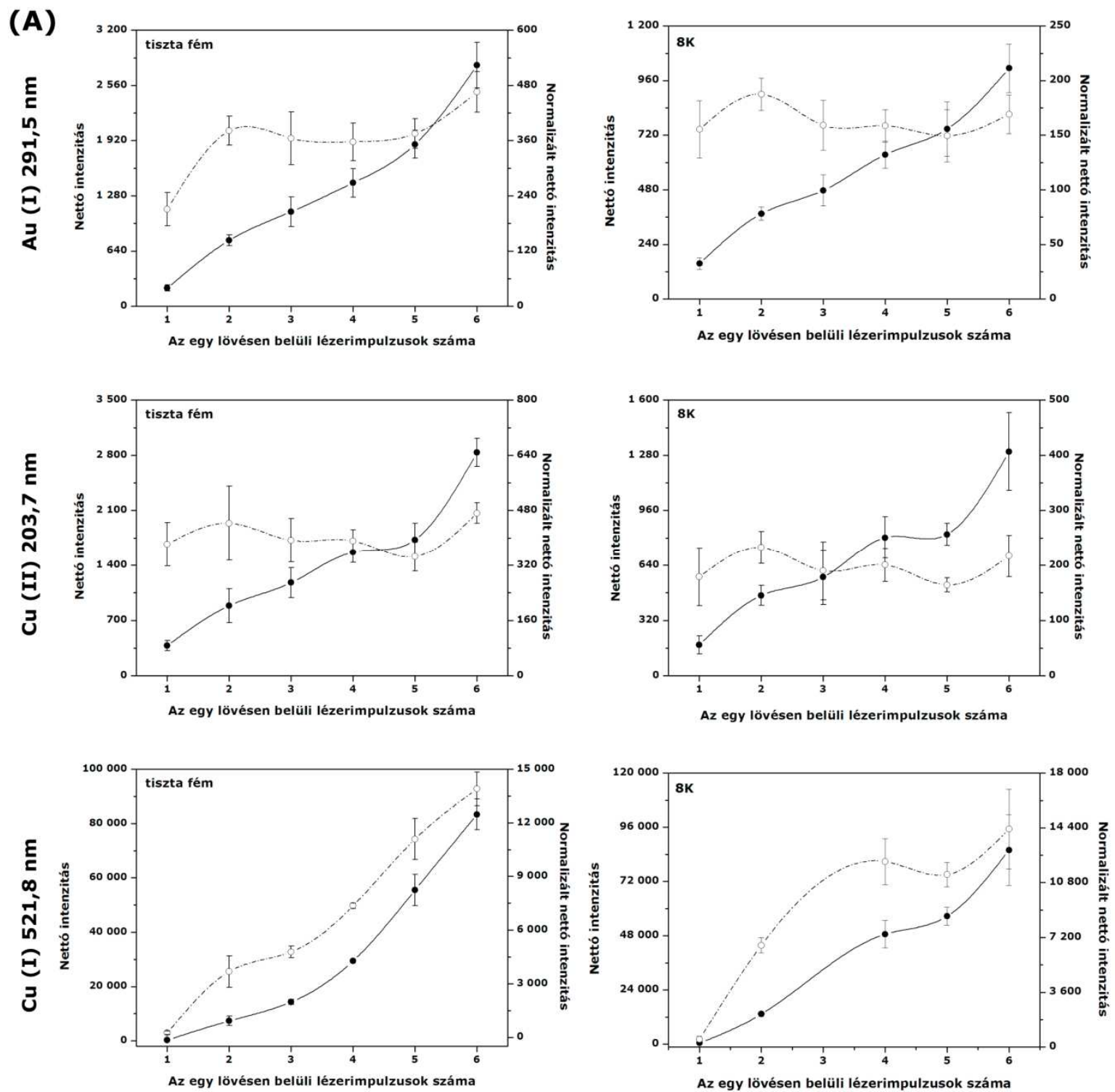

4-15. (A) ábra: A nettó $(\bullet)$ és az energiával normált nettó $(\bigcirc)$ intenzitás összehasonlítása ugyanazon spektrumvonalak, de két különböző mátrix esetén, az egy lövésen belüli impulzusszám függvényében. A hibasávok 24, illetve 25 összimpulzusszámból adódó szórást jelölik (4.2.2. fejezet).

A relatív nettó jelnövekedés ugyanarra a spektrumvonalra eltérő különböző mátrixokban, de következetesen alacsonyabb az összetettebb mátrixban. Továbbá az is jól lát- 
szik a grafikonokon, hogy ugyanabban a mátrixban a különböző elemek vonalai eltérően viselkednek.
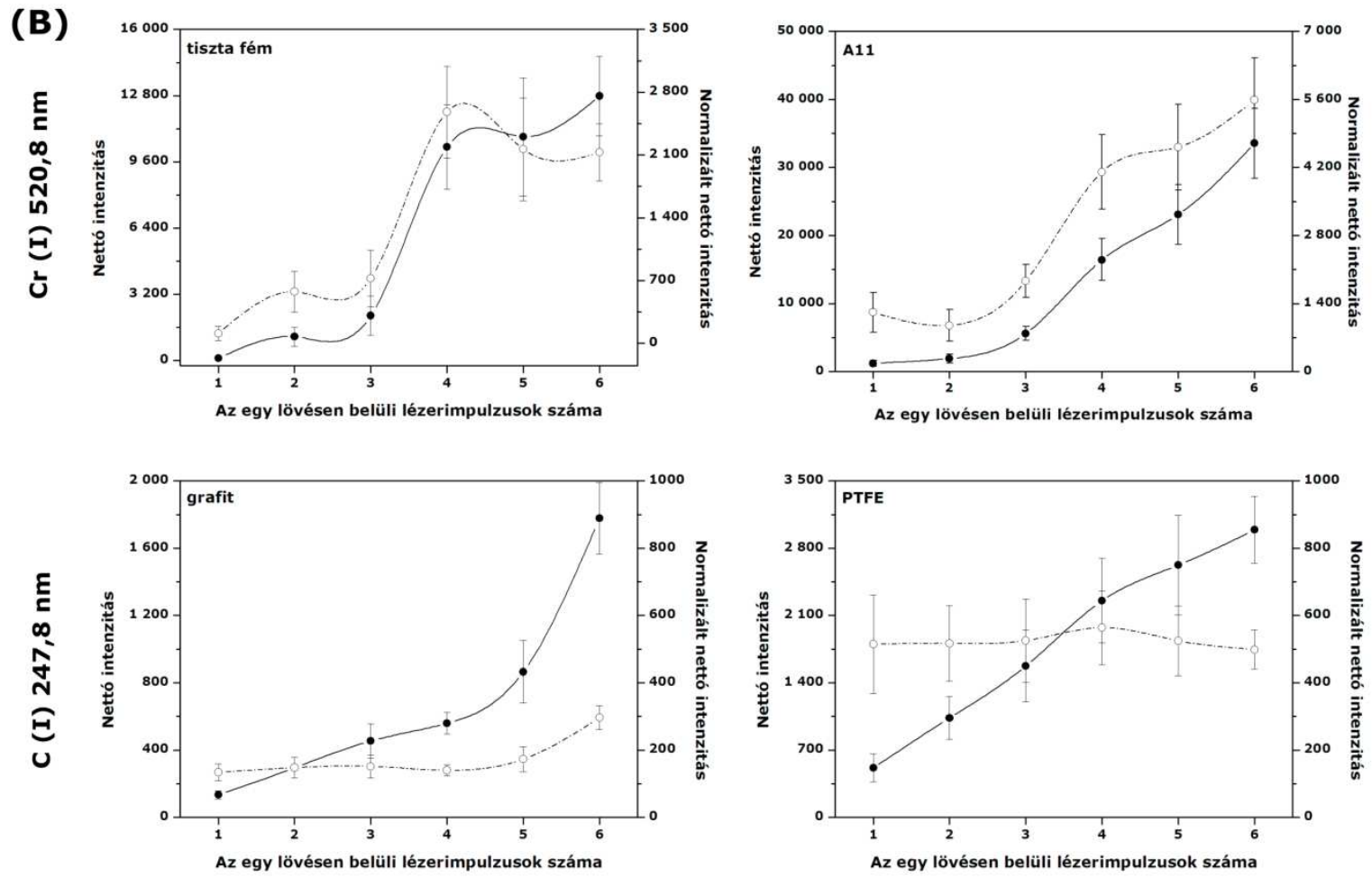

4-15. (B) ábra: A nettó ( $)$ és az energiával normált nettó $(\bigcirc)$ intenzitás összehasonlítása ugyanazon spektrumvonalak, de két különböző mátrix esetén, az egy lövésen belüli impulzusszám függvényében. A hibasávok 24, illetve 25 összimpulzusszámból adódó szórást jelölik (4.2.2. fejezet).

\subsubsection{Ismételhetőség}

A kvantitatív analitikai mérések szempontjából nagy jelentőséggel bíró teljesítményjellemző a mérések ismételhetősége, mivel közvetlenül befolyásolja a módszer kimutatási határát és az analízis precizitását. A LIBS módszert elsősorban szilárdmintás mikroanalitikai mérésekre alkalmazzák, ennélfogva viszonylag alacsony ismételhetőség jellemzi, akárcsak más hasonló technikákat, mint például a szilárdmintás elektrotermikus elpárologtatással működő atomabszorpciós spektroszkópiát (SS-ETAAS) vagy a lézerablációs mintabevitellel kiegészített ICP-MS-t. A LIBS esetében a jelingadozásnak számos forrása lehet, például a lézerimpulzusok energiájának ingadozása, a plazmajellemzők lövésről-lövésre való változása, a minta mikroheterogenitása, stb. Az SP-LIBS-re jellemző szórás kisszámú mérés (10-50) esetében 15-25\% körül van. Ez azonban javítható nagyszámú mérés (500-2500) elvégzésével vagy valamilyen jelnormalizációs eljárás alkalmazásával. 
Az ismételhetőséggel kapcsolatos méréseink során a teljes impulzusszám (lövések száma x az egy lövésen belüli impulzusszám) a mérések során mindvégig állandó, 24 (ötimpulzusos esetben 25) volt, vagyis 24 egyimpulzusos lövéssel, 12 kétimpulzusos lövéssel, 8 háromimpulzusos lövéssel, stb. dolgoztunk. Ily módon kiküszöbölhető volt a teljes impulzusszám változásának a szórásadatokra gyakorolt esetleges hatása. Az egyes lövések között vízszintesen mozgattuk a mintát és a reprodukálható mintapozícionáláshoz egy HeNe segédlézert is használtunk. A kiértékelés során kétoldali háttérkorrekcióval meghatározott nettó intenzitásokkal dolgoztunk.

Idő- és térbeli integrációval működő MP-LIBS rendszerünk esetében megfigyeltük, hogy az ismételhetőség nagymértékben javul, ha növeljük az egy lövésen belüli lézerimpulzusok számát. Amint azt különböző fémek emissziós vonalaira láthatjuk a 416. ábrán, a nettó intenzitások relatív standard deviációja (tapasztalati szórása) egyöntetűen csökken az impulzusszám növekedésével: 20-40\%-ról 5-10\%-ra. Fontos megjegyezni, hogy ezek az értékek relatíve kisszámú mérésből származnak (összesen max. 25 impulzus) és a mérési eredmények értékelése során semmilyen jelnormalizációs eljárást nem alkalmaztunk, csak egyszerü átlagolással számítottuk a végeredményeket. A kapott szórásadatok azonban így is összehasonlíthatóak vagy jobbak más kutatócsoportok által, DP-LIBS módszerrel, nagyszámú (50 vagy több száz) mérésből számított eredményekkel [57, 94, 118]. Csoportunk korábbi munkáiban [pl. 35] már bemutattunk hasonló eredményeket más spektrumvonalakra is.

A precizitás ilyen nagymértékü javulásához valószínüleg nagymértékben hozzájárul az időintegrációs detektálás, amelyet kísérleti berendezésünkben alkalmazunk. A mérések integrációs ideje ( $2 \mathrm{~ms}$ ) a plazma egész, analitikailag hasznos élettartamára kiterjed, ellentétben a nagy időfelbontású LIBS berendezésekkel, amelyeknél az integrációs időt néhány us-nak szokás választani. Mindezeken túl, kísérleti körülményeink között a jel/zaj viszony is szignifikánsan javul. Úgy gondoljuk tehát, hogy az ismételhetőség javulása ezen hatások eredményeként jön létre. 


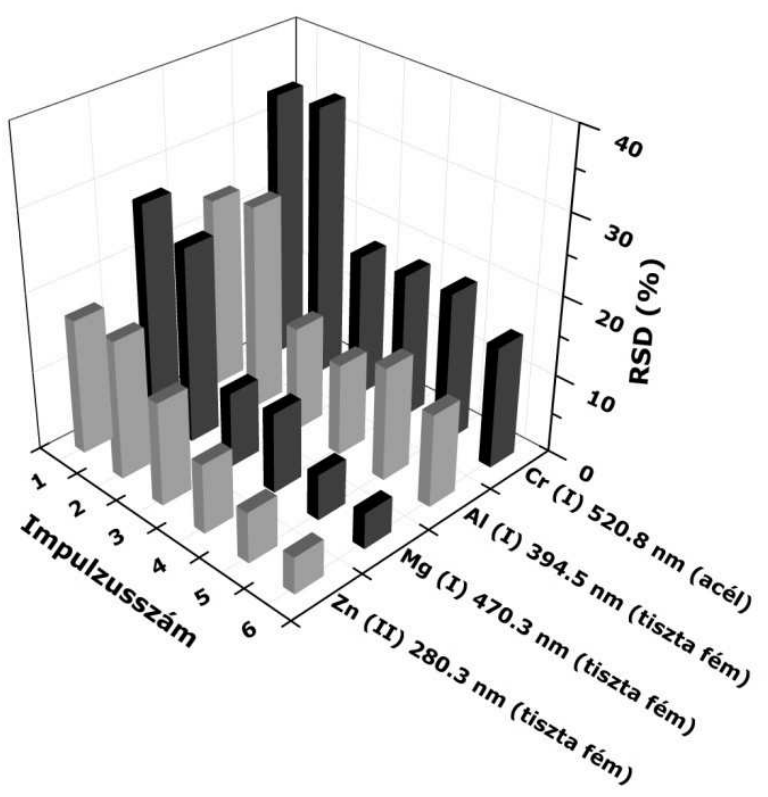

4-16. ábra: A relatív standard deviáció (ismételhetőség) értékei néhány spektrumvonalra az impulzusszám függvényében.

Minden adat azonos összimpulzusszámtól származik.

\subsubsection{Kalibrációs görbék}

A 4-17. ábra néhány, atomvonalakra felvett kalibrációs görbét mutat be, különböző ötvözetekben: Cu és $\mathrm{Zn}$ vonalra aranyötvözetben, $\mathrm{Cr}$ vonalra acélban és Sn vonalra forrasztóónban. A lehető legjobb összehasonlítás érdekében az egy és hat impulzussal meghatározott görbék láthatók, elemenként közös diagramon. A Zn vonalon az egyimpulzusos jel túl gyenge volt megbízható kalibráció elvégzéséhez, így ebben az egy esetben a kétimpulzusos görbét ábrázoltam. Jól látható, hogy a hatimpulzusos görbék lineáris dinamikus tartománya jóval szélesebb. Az SP-LIBS-ben a lineáris tartomány felső széle "erős" atomvonalak esetében mindössze néhány százalék koncentrációig terjed. A hatimpulzusos esetben az illesztett görbe néhány tíz százalékig vagy esetleg még tovább is jó közelítéssel lineáris (lásd még az Au vonalak aranyötvözetekben felvett kalibrációs görbéit a 4.3. fejezetben). Arra is szeretném felhívni a figyelmet, hogy a szóban forgó, 4-17. ábra grafikonjain feltüntetett spektrumvonalak "erős" vonalak, amelyek átmeneti valószínűsége $10^{7} \mathrm{~s}^{-1}$ nagyságrendü és gerjesztési energiájuk csak néhány eV. 

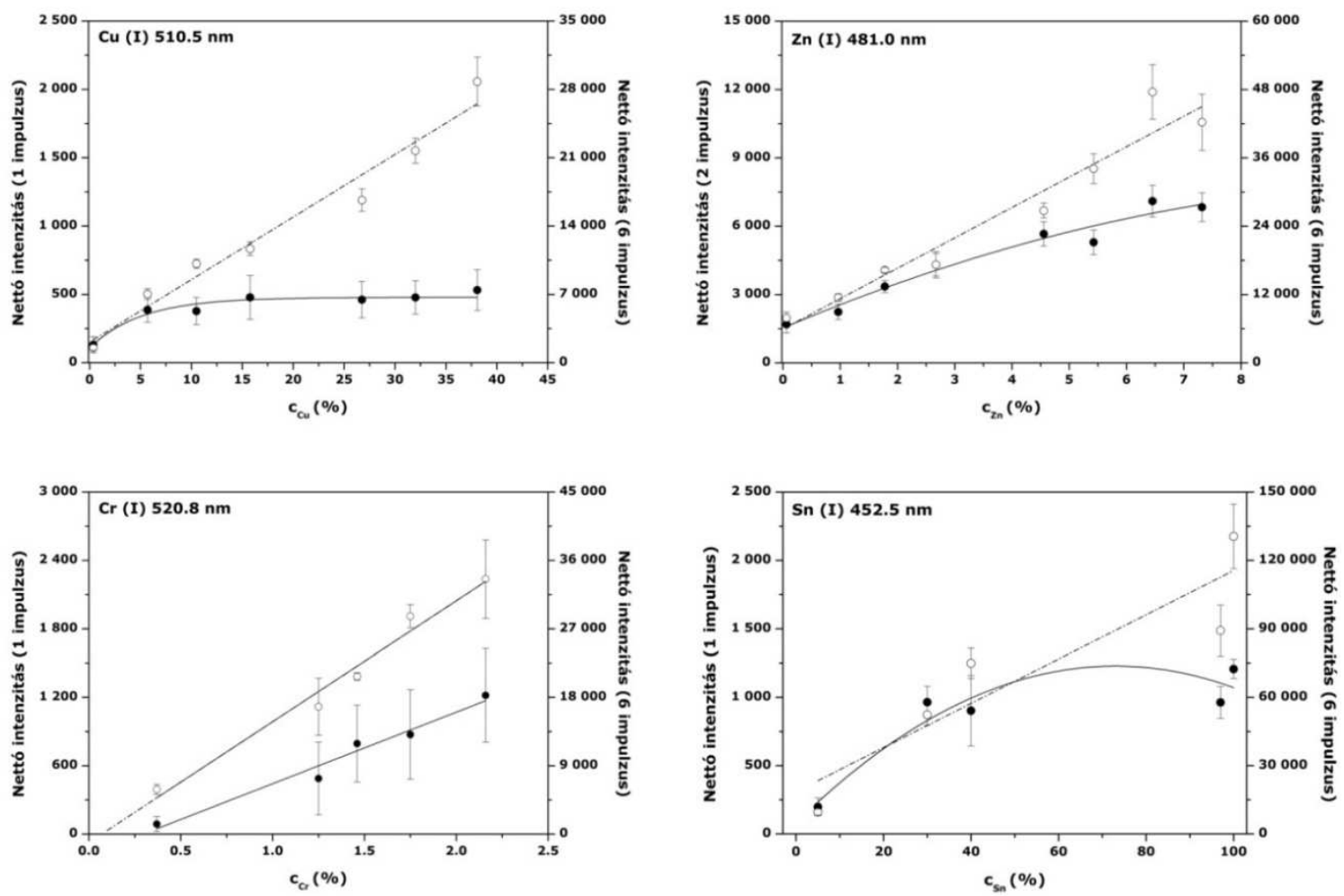

4-17. ábra: Az egy $(\bullet)$ és a hat impulzussal $(O)$ meghatározott kalibrációs görbék összehasonlítása néhány atomvonal esetében. A hibasávok 24, illetve 25 összimpulzusszámból adódó szórást jelölik (4.2.2. fejezet).

Figyelembe véve, hogy az irodalom az SP-LIBS kalibrációs görbék legjellemzőbb tulajdonságai között említi az önabszorpció miatti telítési jelleget (pl. [86]), nagyon előnyösnek tekinthetők tapasztalataink, melyek szerint az MP-LIBS esetében az önabszorpció hatása elhanyagolható. Valószínűleg ez az MP-LIB plazma gyors kiterjedésének következtében kialakuló kisebb részecskesürüség következménye, amelyet leginkább a lökéshullámfront mögött kialakuló alacsony nyomás okoz. Ezt támasztja alá az a több kutatócsoport által is tapasztalt tény, hogy csökkentett nyomáson jelentősen kiszélesedik az SP-LIBS kalibrációs görbék lineáris dinamikus tartománya [104, 157].

A nyomás befolyásolja az ütközéses gerjesztési és relaxációs folyamatokat is, így az emitterek "hígulása”-kor (számkoncentrációjának csökkenésekor) a fényt térbeli felbontással gyűjtő optikai rendszer alkalmazásával jelcsökkenést (telítődési jelleget) is tapasztalhatunk. Térbeli és időbeli integráció alkalmazásakor azonban, amely gyakorlatilag a plazma teljes élettartama alatt annak egészéből gyűjti a fényt, az integrált emissziós jel nem mutat csökkenést. 


\subsubsection{Kimutatási határok}

A fent bemutatott eredmények alapján egyértelműen várható, hogy többszörös lézerimpulzusok alkalmazásával szignifikáns javulás érhető el a módszer kimutatási határaiban. A csökkenő szórás (javuló ismételhetőség) és a növekvő érzékenység együttes következményeként a kimutatási határok (LOD, a $3 \sigma$ IUPAC definíció szerint számolva) valóban jelentős javulást mutatnak nemcsak az egyimpulzusos, hanem a kétimpulzusos értékekhez képest is. Ezt illusztrálják a 4-2. táblázatban bemutatott adatok, amelyek mellett feltüntettük a meghatározási határokat is (LOQ, a $6 \sigma$ definíció alapján számítva). A vizsgált elemek és spektrumvonalak esetében az MP-LIBS értékek 4,2-16,7-szeres javulást mutatnak a DP-LIBS-hez képest.

Fontos ismét megemlíteni, hogy ezek az eredmények csak néhány lövésből származnak (6 impulzus esetén 4 lövés), amely jelentősen lecsökkenti a mérés és a kiértékelés időtartamát. A kvantitatív LIBS alkalmazások során a leggyakrabban akár több száz vagy ezer spektrum átlagolásával kapják az eredményeket, így csökkentve a mérések szórását. A 4-2. táblázatbeli kimutatási határok abszolút értékben viszonylag magasak (6 impulzusnál 100-1000 ppm nagyságrendűek), azonban könnyen tovább csökkenthetők, ha nagyobb impulzusenergiájú lézerrel (nagyobb lövésenkénti ablált anyagmennyiséggel és plazmahőmérséklettel) és/vagy érzékenyebb spektrométerrel dolgozunk. Az MP-LIBS módszer kvantitatív teljesítményjellemzőinek további javítása is reális célkitűzés tehát, amint azt egyes SP-LIBS és DP-LIBS irodalmi adatok jelzik (pl. 123]).

\begin{tabular}{cccccc}
\hline \multirow{2}{*}{ Speciesz } & \multirow{2}{*}{$(\mathbf{n m})$} & \multicolumn{2}{c}{ LOD (mg/g) } & \multicolumn{2}{c}{ LOQ ( $\mathbf{m g} / \mathbf{g})$} \\
\cline { 3 - 6 } & & $\mathbf{2}$ impulzus & $\mathbf{6}$ impulzus & $\mathbf{2}$ impulzus & $\mathbf{6}$ impulzus \\
\hline Cu I & 510,5 & 34,69 & 2,65 & 69,37 & 5,30 \\
Zn I & 481,0 & 6,94 & 0,51 & 13,87 & 1,02 \\
Cr I & 520,8 & 5,19 & 0,31 & 10,37 & 0,62 \\
Sn I & 452,5 & 20,74 & 4,87 & 41,49 & 9,75 \\
\hline
\end{tabular}

4-2. táblázat: A 4-17. ábrán bemutatott kalibrációs görbék és a 30 szabály alapján számított, kettő és a hat impulzussal kapott kimutatási határok összehasonlítása.

\subsection{5. Összefoglalás}

Eredményeink alapján egyértelműen kijelenthető, hogy az analitikai teljesítményjellemzők javításának céljából mindenképpen érdemes egy helyett több lézerimpulzussal dolgozni a LIBS alkalmazások során, mégpedig időbeli és térbeli átlagolás 
alkalmazása mellett. Tapasztalataink szerint a jelnövekedés még akkor is megvalósul, ha az impulzusok közötti késleltetési idő eléri az 50 s értéket.

Az impulzuskövetési idő, az impulzusenergia és az impulzusok száma igen jelentős hatással bírnak az MP-LIB plazmák emissziós jellemzőire, amint azt a korábbi 4.1. fejezetben is megmutattuk. Várhatóan tehát még további javulás érhető el egyes teljesítményjellemzőkben (pl. kimutatási határ), ha az impulzuskövetési időket csökkentjük, az impulzusenergiát valamint az impulzusok számát pedig növeljük. A rendszerünkben jelenleg alkalmazott lézer azonban sajnos nem teszi lehetővé nagyobb értékek elérését, sőt az impulzus paraméterek szabad, direkt szabályozását sem. Érdemes azonban megemlíteni, hogy a jelenleg általunk alkalmazott ismétlési ráta (25 $\mu \mathrm{s}$ impulzuskövetési idő 40 kHz-nek felel meg) és impulzusszám egyetlen, szabályozható lézerforrással való elérése jelentős technikai feladatot jelent. Többek között ez is az oka annak, hogy az irodalomban rendkívül ritkák az MP-LIBS alkalmazások. 


\subsection{Analitikai alkalmazások}

\subsubsection{Aranyötvözetek kvantitatív elemzése}

Kutatócsoportunk korábbi eredményei közé tartozik egy új, a lineáris korreláción alapuló kalibrációs módszer (általánosított lineáris korrelációs kalibráció, GLCM) kifejlesztése [105, 106], amely koncepcióját az 1.3.2.4. fejezetben már én is részletesen ismertettem. Ezen kalibrációs módszer alkalmazása a LIBS spektroszkópiában különösen előnyös, két fontos tulajdonsága miatt. Az egyik ilyen tulajdonság, hogy a kalibrációs görbe robusztus, érzéketlen a spektrumok lineáris transzformációjára (alapvonal-eltolódás, érzékenység-változás), következésképpen a kalibrációs görbék hosszú ideig használhatók, amely tulajdonság jól kiaknázható ipari és terepi alkalmazások során, amely területeken a LIBS spektroszkópia nagy perspektívával rendelkezik. A másik releváns tulajdonsága, hogy a lineáris korrelációs együttható robusztussága a mérések precizitását nagymértékben javítja. Ez a segítség a LIBS mérési adatokra is ráfér, hiszen mint ismeretes, a SP-LIBS adatok szórása számottevő.

Mindezek miatt célul tűztük ki, hogy megvizsgáljuk, lehetséges-e az MP-LIBS és a GLCM módszerek kombinálásával nagy pontosságot és precizitást igénylő kvantitatív meghatározásokat is elvégezni. Alkalmazásul az ötvözetek területén az elemanalitika számára az egyik legnagyobb kihívást jelentő mérési feladatot, a nemesfémötvözetek, ezen belül az aranyötvözetek elemzését választottuk. Ezen a területen sok évtized óta a túzi próbát [167] használják, mint standardizált analitikai módszert. A tűzi próba pontossága és precizitása valóban kiváló (ideális körülmények között 0.1$0.5 \%$ ), azonban előzetes információkat igényel az ötvözet összetételéről és végrehajtása nagyon időigényes (kb. 24 óra). Az MP-LIBS/GLCM módszer alkalmazása ezen a területen a nagy mérési sebesség és az kis mintaigény miatt is igen ígéretes.

\section{Elökísérletek}

A komoly kihívást jelentő analitikai alkalmazás kivitelezése előtt előkísérleteket folytattunk a minták (egy kilenctagú, bizonylatolt aranytartalmú aranyötvözet sorozat) homogenitása, a bennük jelenlévő ötvözőelemek anyagi minőségének megállapítása és az emissziós jelek koncentrációtól való függésének tanulmányozása céljából.

A 4-18. ábra mutatja be a vizsgált aranyötvözetek jellegzetes MP-LIBS spektrumát az UV és Vis tartományban. A spektrumok szerint az arany mellett három ötvözőelem, réz, cink és nikkel fordulnak elő a mintákban. Ezeknek az elemeknek a jelenlétét később savas roncsolás után kivitelezett ICP-AES elemzéssel is ellenőriztük. Az ICPAES mérések az ötvösiparban szokásos gyakorlatnak („legát"-ok alkalmazása) megfe- 
lelő, összetételbeli összefüggést is kimutatták, amely szerint az ötvözőelemek koncentrációaránya a sorozaton belül állandó. Az áttekinthetőség kedvéért a 4-18. ábrán csak az analízishez felhasznált, spektrális zavarástól mentes vonalakat jelöltük be. A 24 karátos minta spektrumában is láttuk az ötvözőelemek nyomait, amely eredmények összhangban vannak a bizonylatoláskor használt tüzi próba eredményeivel, hiszen eszerint az aranytartalom a 24 karátos mintában 994,3\%o (3.2 fejezet).
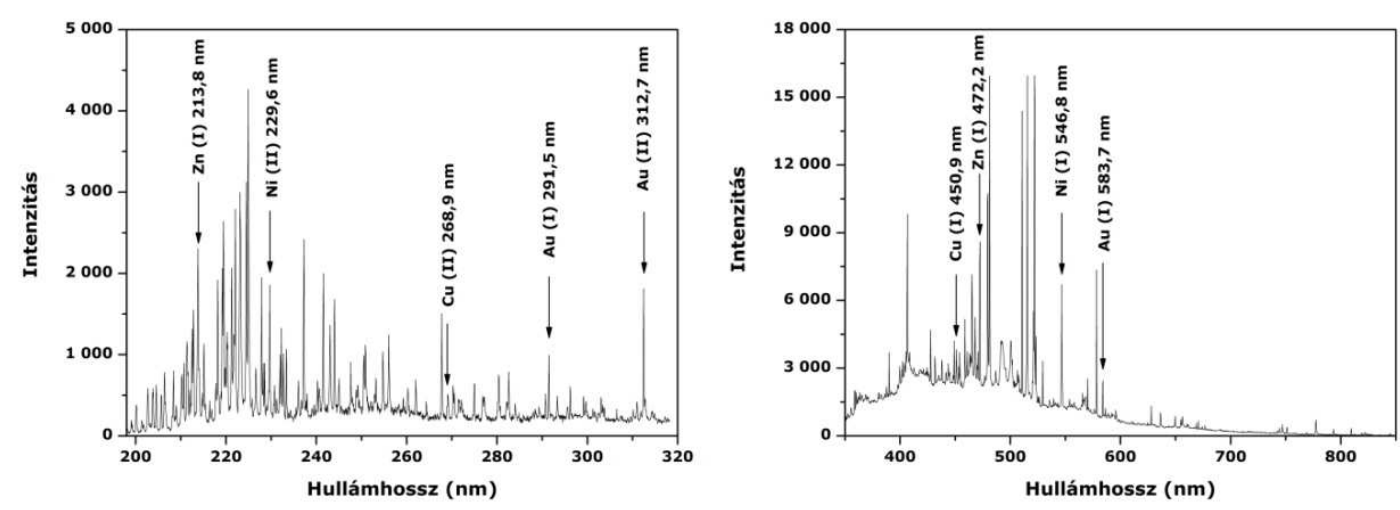

4-18. ábra: Egy vizsgált aranyötvözet LIBS spektrumai az UV és a Vis tartományban.

A homogenitás vizsgálatát azért tartottuk szükségesnek, mert a LIBS módszer a mikropróbás módszerek közé tartozik, így a minták átlagos (bulk) összetételéről csak nagyszámú ismételt mérés alapján tud megbízható adatokat nyújtani. A nemesfém vizsgálat során azonban a minta nagyfokú destrukciója nem kívánatos; kisszámú lövésből az MP-LIBS módszertől azonban csak a minta megfelelő homogenitása esetén várható el használható pontosságú koncentráció adat.

A homogenitás tanulmányozása érdekében tanulmányoztuk az MP-LIBS jelek szórását az Au (II) 312,7 nm-es és a Zn (I) 213,8 nm-es vonalán minden mintánál. A mérések során mindvégig 7 impulzussal dolgoztunk. Öt lövés történt a minta ugyanazon pontján és 3 párhuzamos mérést végeztünk a minták különböző pontjaiban. $A z$ eredményeket a 4-19. ábra illusztrálja. A szórásértékek mind a különböző helyeken ugyanazon mintán végzett mérések, mind pedig az egyes mintákat összevetve összehasonlíthatóak voltak, amelyből arra következtethettünk, hogy a minta heterogenitása ebben az esetben nem befolyásolta szignifikáns mértékben a mérési eredményeket. Ezek alapján a mintafelület mérés közben történő megújítása (automatikus eltolás vagy forgatás, ami a LIBS és LA alkalmazásokban sokszor alkalmazott gyakorlat) sem kínál szignifikánsan jobb eredményeket. Ez lehetővé teszi a mérések lehető legkisebb destruktivitás mellett való elvégzését. 




4-19. ábra: 5 ismételt lövéstől származó spektrumok vonalintenzitásainak szórásai (8-16 karátig Zn (I) 213,8 nm és 18-24 karátig Au (II) 312,7nm). Az adatgyüjtés során 3 párhuzamos mérést végeztünk a minták különböző pontjain.

Következő lépésben megvizsgáltuk a jelintenzitás aranytartalomtól való függését. Ez a vizsgálat kettős célt is szolgált. Egyfelől a spektrumvonalak spektrális zavarmentességét ellenőriztük, másfelől adatokat gyűjtöttünk a "klasszikus" kalibráció végrehajtásához, amelyet a GLCM módszer teljesítőképességének összehasonlítására kívántunk felhasználni. A kapott adatokat a 4-20. ábra mutatja be. A grafikon két arany és egy-egy ötvözőelem elemzővonalának "klasszikus" kalibrációs görbéjét is mutatja. Megfigyelhető, hogy a mérési pontokra viszonylag jó linearitással illeszthető egyenes még a magas koncentráció tartományban is (több tíz \%). Ezek az adatok is demonstrálják tehát a 4.2. fejezetben már leírt megfigyelésünket, miszerint az önabszorpció hatása az MP-LIBS jelekre kismértékű; itt is csak kb. 80\% koncentráció felett jelentkezik a hatás. A linearitás jó és a dinamikus tartomány tehát elég széles, azonban az adatok szórása nem ígér nagyfokú pontosságot a közvetlen kvantitatív alkalmazás („klasszikus" kalibráció) esetére. 

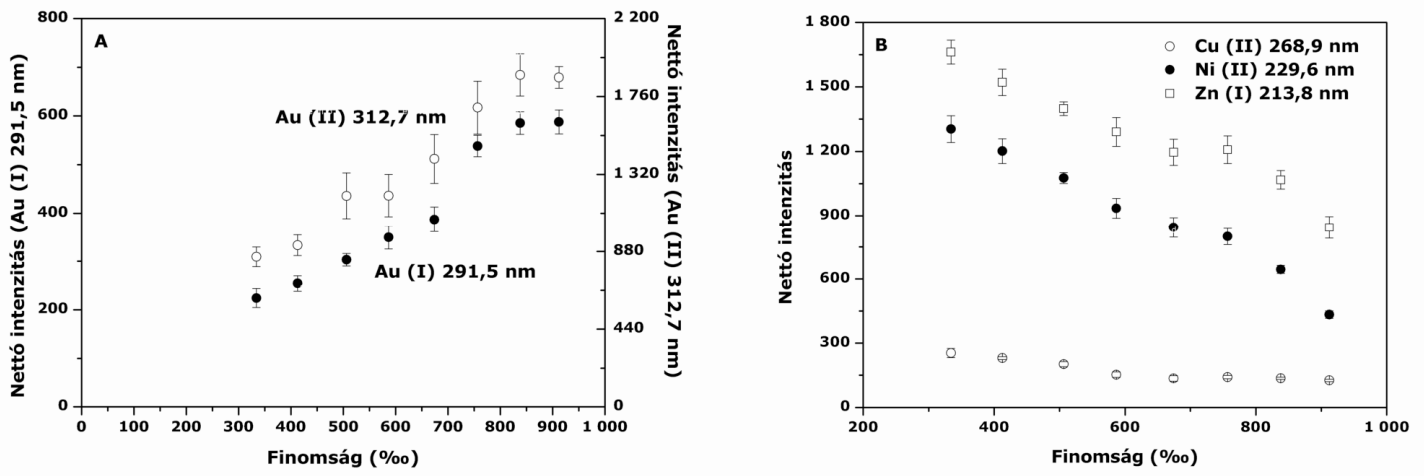

4-20. ábra: A jelintenzitás aranytartalomtól való függése (A) két kiválasztott arany vonal és (B) egy-egy kiválasztott ötvözőelem vonal esetében („klasszikus” kalibrációs görbék).

A hibasávok 5 ismételt mérésből adódó szórásadatok.

\section{A GLCM módszer paraméter-optimálása és alkalmazása}

A GLCM módszer jelen alkalmazása során az aranyat választottuk referencia elemnek és a 24 karátos minta spektruma volt a referencia spektrum. Nagy pontossági igény esetén a GLCM kalibráció elvégzése előtt is szükséges a kiértékelési paraméterek optimálása, hogy a lehető legnagyobb meredekségű és linearitású kalibrációs görbéket érhessünk el. Mivel a paraméterek értékeinek viszonylagos nagy száma miatt a teljes körű optimálás igen sok számítás elvégzését tette volna szükségessé és kevés általánosítható adattal szolgált volna, ezért úgy jártunk el, hogy a lényeges paraméterek felhasználásával 10 különböző kombinációt (a-j) állítottunk össze (4-3. táblázat) és ezek mindegyikére kiszámoltuk a kalibrációs görbéket. A felhasznált paraméterek a következők voltak: (1) a spektrális maszk ablakszélessége a kiválasztott spektrumvonal körül, (2) a mintákban jelenlévő elemek figyelembe vett vonalai (egy választott aranyvonalat mindig tartalmazott) és (3) a spektrális tartomány (UV vagy Vis). Fontos ismét megjegyezni, hogy a vizsgált aranyötvözetek minőségi összetétele megegyezett és az ötvözőelemek aránya minden mintában állandó volt. 


\begin{tabular}{cccc}
\hline \hline Adatsor & $\begin{array}{c}\text { Au } \\
\text { vonal } \\
(\mathbf{n m})\end{array}$ & $\begin{array}{c}\text { Az ötvözőelemek } \\
\text { figyelembe } \\
\text { vett vonalai (nm) }\end{array}$ & $\begin{array}{c}\text { Maszk szélessége (pi- } \\
\text { xel) }\end{array}$ \\
\hline a & 291,5 & Zn 213,8; Cu 268,9; Ni 229,6 & 1 \\
\hline b & 312,7 & Zn 213,8; Cu 268,9; Ni 229,6 & 1 \\
c & 291,5 & Zn 213,8 & 1 \\
d & 291,5 & Cu 268,9 & 1 \\
\hline e & 291,5 & Ni 229,6 & 3 \\
f & 291,5 & Zn 213,8; Cu 268,9; Ni 229,6 & 5 \\
\hline g & 291,5 & Zn 213,8; Cu 268,9; Ni 229,6 & 3 \\
\hline h & 291,5 & Ni 229,6 & 5 \\
\hline i & 291,5 & Ni 229,6 & 1 \\
\hline \hline
\end{tabular}

4-3. táblázat: A korrelációs kalibrációs görbék (a-j) optimálása során felhasznált paraméterek.

Az optimálás eredményeképpen kapott kalibrációs görbék a 4-21. ( $A$ ) és (B) ábrán láthatók. A GLCM módszer használatakor szokásos harmadfokú polinomot illesztettünk minden adatsorra. Látható, hogy a görbék görbülete különböző, némelyik konvex, némelyik pedig konkáv, de mindegyik monoton, nem periodikus, így valóban használható kalibrációs célokra. Az egyes pontok (a korrelációs koefficiensek) szórása nagyon kicsi, tipikusan 1-2\%, hasonlóképpen a korábbi tanulmányokban tapasztaltakhoz [105, 106]. A lineáris korrelációnak a jelingadozásra gyakorolt tompító hatása jól észrevehető a szórásértékeknek a "klasszikus” kalibráció során kapottakkal való öszszehasonlításakor (4-20. ábra).
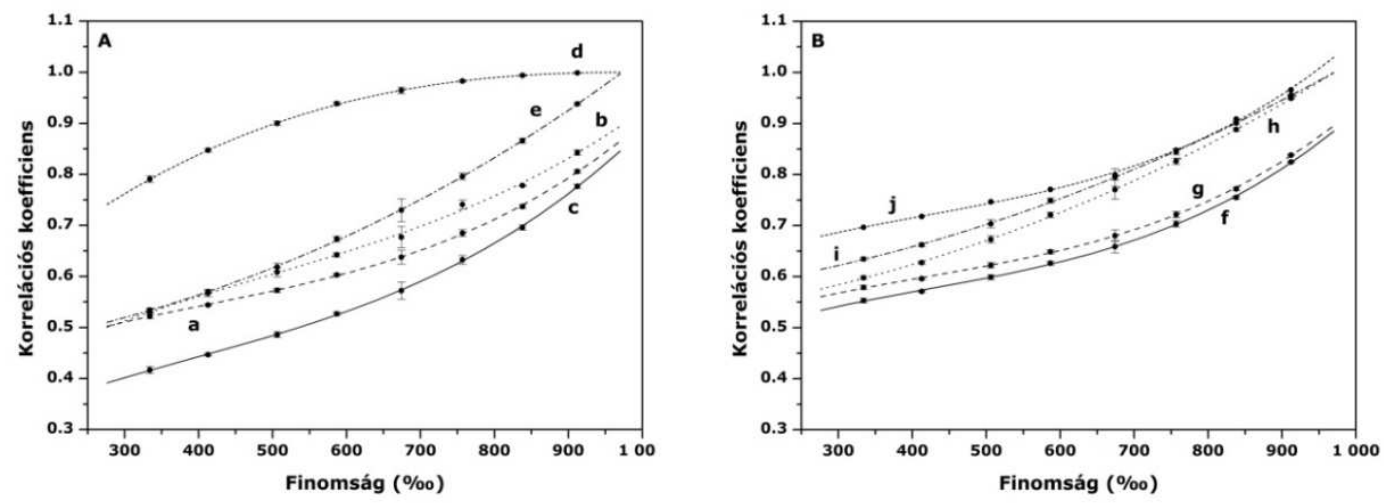

4-21. ábra: A 4-3. táblázatban feltüntetett paraméterek alapján számított korrelációs kalibrációs görbék. A hibasávok 5 ismételt mérésből adódó szórásadatok. 
A GLCM kalibráció ezen tulajdonsága kivételesen előnyös olyan igényes analitikai alkalmazások során, mint például az általunk tervezett aranytartalom meghatározás. A 4-21. ábráról megállapítható, hogy az "e" görbe rendelkezik a legnagyobb meredekséggel és a legjobb linearitással (legkisebb görbülettel), így ez a legalkalmasabb kvantitatív analitikai alkalmazásra. Ezért a további, kvantitatív meghatározásra ezen paraméterek halmazát (4-3. táblázat, e) választottuk ki.

Hangsúlyozzuk, hogy természetesen nem azt állítjuk, hogy minden hasonló alkalmazásban ezek a paraméter értékek lennének a legoptimálisabbak, vagy hogy ezek

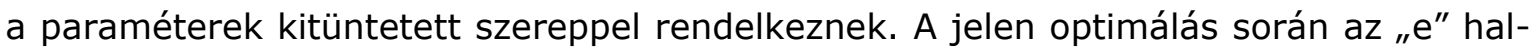
mazban található paraméterek alapján számított kalibrációs görbe szolgáltatta a legjobb eredményeket. Azt azonban természetesen javasoljuk, hogy a paraméterek hasonló módon történő optimálása a GLCM kalibráció minden alkalmazása előtt történjen meg a lehető legjobb analitikai teljesítőképesség elérése érdekében.

Az analitikai pontosság vizsgálatának folyamata a következőképpen történt: első lépésben kiválasztottunk egy mintát a sorozatból, amelyet ismeretlennek tekintettünk. Ezután az „e" paraméter halmaz felhasználásával végrehajtottuk ennek és a többi minta spektrumának a referenciaspektrummal való korreláltatását. Végül az ismeretlen minta aranytartalmát az adatpontokra illesztett harmadfokú polinom alapján számítottuk ki. Ezt a folyamatot ismételtük meg annyiszor, ahány mintát tartalmazott az ötvözet sorozat, minden esetben más-más mintát választva ismeretlennek (kereszt-teszt). A 4-4. táblázat tartalmazza az öt ismételt mérésből származó végeredményeket a "klasszikus” kalibráció alkalmazásával kapott eredményekkel együtt.

\begin{tabular}{|c|c|c|c|c|c|}
\hline $\begin{array}{c}\text { Nominális } \\
\text { karát- } \\
\text { szám }\end{array}$ & $\begin{array}{c}\text { Bizonylatolt } \\
\text { finomság } \\
(\% \circ)\end{array}$ & $\begin{array}{c}\text { MP- } \\
\text { LIBS+GLCM } \\
\text { módszerrel } \\
\text { meghatározott } \\
\text { finomság }(\%)\end{array}$ & $\begin{array}{c}\text { Abszolút } \\
\text { hiba } \\
(\%)\end{array}$ & $\begin{array}{c}\text { Precizitás } \\
\text { (\%o) }\end{array}$ & $\begin{array}{c}\text { „Klasszikus” } \\
\text { kalibrációval } \\
\text { meghatározott } \\
\text { finomság } \\
(\%)\end{array}$ \\
\hline 8 & 334,1 & 342,1 & 8,0 & 9,0 & 372,9 \\
\hline 10 & 412,7 & 411,3 & 1,4 & 5,2 & 414,8 \\
\hline 12 & 506,3 & 500,4 & 5,9 & 13,7 & 482,9 \\
\hline 14 & 586,8 & 593,9 & 7,1 & 8,4 & 547,7 \\
\hline 16 & 674,2 & 671,5 & 2,7 & 30,5 & 601,0 \\
\hline 18 & 756,8 & 757,1 & 0,3 & 7,8 & 812,2 \\
\hline 20 & 838,1 & 836,8 & 1,3 & 5,2 & 877,9 \\
\hline 22 & 912,2 & 915,8 & 3,6 & 2,8 & 881,1 \\
\hline
\end{tabular}

4-4. táblázat: Az MP-LIBS+GLCM módszerrel kapott végeredmények a tanulmányozott aranyötvözet mintákra. Az eredmények öt ismételt mérésből származnak. 
Láthatjuk a táblázatban, hogy mind az analízis pontossága, mind a precizitása nagyon jó. Az abszolút mérési hiba és a precizitás értékek csak néhány ezrelék nagyságrendűek. A nyolc mintából három esetben pedig az abszolút hiba csak $1 \%$ körüli vagy kisebb. Ezek az értékek nagyon közel esnek az aranyötvözetek bevizsgálására használt tűzi próba teljesítőképességéhez, ugyanakkor a végrehajtáshoz nem szükségesek előzetes információk vagy hosszú idő. Ennyire pontos és precíz meghatározás elérhetetlen SP-LIBS és hagyományos kalibráció alkalmazásával.

Munkánk során demonstráltuk, hogy az MP-LIBS módszer a GLCM kalibrációval kiegészítve alkalmas lehet aranyötvözetek kvantitatív analízisére olyan pontossággal és precizitással, amely összemérhető a tűzi próba teljesítményjellemzőivel, hiszen sikerült $0,3-8 \%$ pontossággal meghatároznunk ötvözeteink aranytartalmát. Korábban egy spanyol és egy olasz kutatócsoport is próbálkozott az aranyötvözetek mennyiségi analízisével és elmondható, hogy eredményeik pontossága a miénkhez hasonló. Tognoni és munkatársai analitikai módszere az általuk kifejlesztett CF-LIBS eljárásra alapult $[184,185]$ és mindkét tanulmányban kb. 0,3-6\% pontosságról számoltak be. Luque de Castro és munkatársai a LIBS spektroszkópiát a PLS statisztikai módszerrel kiegészítve alkalmazták [186]; az általuk elért pontosság 4-10\%o volt. Fontosnak tartjuk hangsúlyozni azonban, hogy az általunk bemutatott MP-LIBS/GLCM módszer matematikailag lényegesen egyszerűbb, könnyen végrehajtható és alkalmazása több járulékos analitikai előnnyel is jár. 


\subsubsection{Forrasztófémek kvantitatív elemzése}

Egy további analitikai feladat, amelyre az MP-LIBS spektroszkópia módszerét sikeresen alkalmaztuk, az ón-ólom ötvözetek (forrasztófémek) összetételének meghatározása volt.

A környezetvédelmi megfontolásokból bevezetett különböző EU szabványok, például a WEEE és az RoHS [189] miatt a gyártóknak és a beszállítóknak egyre több, a termékeik elemösszetételével kapcsolatos határértéket kell teljesíteniük. A WEEE direktíva célja az elektromos és elektronikus készülékek hulladékainak csökkentése és újrahasznosítása. Az RoHS direktíva az elektromos és elektronikai iparban használt hat veszélyes anyag(csoport)ra vonatkozóan tartalmaz megkötéseket: ez az ólom, higany, kadmium, króm(VI), valamint a PBB (polibrómozott-bifenilek) és a PBDE (polibrómozott-difenil-éterek), mely utóbbiak pl. számos mủanyagban is használt égéscsökkentő vegyületek. Ezekre az anyagokra a határérték 0,1 $\mathrm{m} / \mathrm{m} \%$, kivéve a kadmiumot, amelyet az alkatrészek legfeljebb 0,01 $\mathrm{m} / \mathrm{m} \%$-ban tartalmazhatnak. Mivel az alkatrészeknek külön-külön is teljesíteniük kell az előírást, ezért a forrasztófémötvözetek - amelyek hagyományos összetevői az ón és ólom - is célkeresztbe kerültek. Az ROHS szabvány teljesítése érdekében, nem utolsósorban az elektronikai ipari munkahelyek (forrasztó dolgozók) védelmében mára már számos helyettesítő ólommentes forrasztófém ötvözeteket kidolgoztak. A megfelelőség vizsgálata, illetve az elektronikai hulladékok megfelelő feldolgozhatósága érdekében szükségessé vált tehát egy gyors elemanalitikai eljárás használata, amellyel a forrasztófémek ólomtartalma ellenőrizhető.

A fentieken túl a forrasztófémek (nyom)elemösszetétele terrorista események felderítése kapcsán (pl. egy robbanószerkezet időzítő áramkörének forrasztásai) is nagy jelentőségü információvá válhat, hiszen ez alapján felderíthető az ötvözet gyártója, eredete és így a nyomozó hatóságok eljuthatnak az elkövetőhöz [190].

A forrasztófémek összetételének vizsgálatára a klasszikus eljárás természetesen az ötvözetből való mintavétel, majd annak savas roncsolása, végül oldatmintás atomspektroszkópiai módszerekkel a mérés elvégzése. Ez az eljárás meglehetősen időigényes és bonyolult, elsősorban a megfelelő roncsoló elegy kiválasztása miatt. A mai forrasztófém-ötvözetek minőségi és mennyiségi összetétele ugyanis széles skálán változik, igen eltérő kémiai jellegű elemeket tartalmaznak ( $\mathrm{pl} . \mathrm{Sn}, \mathrm{Pb}, \mathrm{Ag}, \mathrm{Cu}, \mathrm{Zn}$ ) és emellett a forrasztandó fémfelületek előkészítése céljából gyantaszerü, enyhén savas karakterű folyatószer („flux") mag is található bennük.

A fenti okoból kifolyólag megcéloztuk egy egyszerü és gyors LIBS módszer kidolgozását a hasonló típusú minták összetételének vizsgálatára. Az MP-LIBS módszerrel kapott eredményeket nem csak a bizonylatolt technikai összetétellel, hanem a klasszi- 
kus nedveskémiai eljárással, ICP-AES módszerrel kapott eredményekkel is össze kívántuk hasonlítani. A kísérletben 5 darab, kereskedelmi forgalomban beszerzett forrasztófém ötvözetet használtunk (ezek felsorolása a 3.2. fejezetben található).

A minták savas roncsolásához az irodalomban kerestünk alkalmas módszereket [190-194]. Kísérleteink során ezek közül többet is kipróbáltunk, míg végül találtunk egyet [190], amely minden tesztmintánk esetén sikeresnek bizonyult. Suzuki és társai módszere szerint a feltárás menete a következő: 100 mg mintát apró darabokra vágtunk. Ezeket $100 \mathrm{ml}$-es feltáró edényekbe helyeztük, $10 \mathrm{ml} \mathrm{cc}$. salétromsavat adtunk hozza, lefedve 20 percig $80^{\circ} \mathrm{C}$-on tartottuk, majd hagytuk szobahőmérsékletüre hülni az edényeket. Ezután $10 \mathrm{ml} \mathrm{cc}$. sósavat adtunk hozzájuk, rázógéppel homogenizáltuk az oldatokat, majd még $10 \mathrm{ml}$ vizet is töltöttünk a mintákhoz és így is alaposan összekevertettük azokat, végül kvantitatíve áttöltöttük a mintákat $250 \mathrm{ml}$-es mérőlombikokba. Az így kapott oldatokat ICP-AES módszerrel elemeztük. A teljes eljárás elvégzése - miután a megfelelő feltáró módszert megtaláltuk - több mint egy napot vett igénybe.

A LIBS méréseket megelőző mintaelőkészítés mindössze annyiból állt, hogy a hengeralakú forrasztófém darabokat kilapítottuk, mikroszkóp tárgylemezre rögzítettük és etanollal letöröltük a felületüket. Ezt követően minden mintán 5 párhuzamos mérést végeztünk, vagyis ötször lőttünk a lézerrel, a lövések között vízszintesen mozgatva a mintát. Minden helyen egy tisztító lövést is alkalmaztunk. A kísérletek során mindvégig 6 impulzussal dolgoztunk. Az ily módon kivitelezett mérés valóban csak néhány (mintánként 1-2) percet igényel és akár in-situ (egy nyomtatott áramköri lapon található ismeretlen forrasztófémen) is végrehajtható.

A kapott LIBS kalibrációs görbék a 4-22. ábrán láthatók. Elmondható, hogy ezek linearitása egészen jó (az $R^{2}$ értékek mindkét esetben elérik a min. 0,95 értéket), ami főként annak fényében figyelemreméltó, hogy a legnagyobb koncentrációjú minta mindkét elem esetében közel $100 \%$-os volt. Az önabszorpció hatását tehát itt is csekély mértékűnek találtuk. A 4-5. táblázatban találhatóak a kalibrációs görbék alapján számított LOD értékek a $3 \sigma$ IUPAC definíció szerint számolva. Az LOD értékekről elmondható, hogy azok viszonylag magasak (kb. 1\%), az ROHS megfelelőség ellenőrzéséhez nem, azonban e jelen alkalmazásban várt koncentráció szinteknek megfelelő, hiszen azok a 30-70\% koncentráció tartományba estek. Amint azt az előző fejezetben is említettem, az LOD értékek még tovább csökkenthetők más fejlettebb kísérleti eszközök alkalmazásával (pl. nagyobb impulzusenergiájú lézer, érzékenyebb spektrométer).

A mérés pontosságát oly módon vizsgáltuk, hogy a közbülső koncentrációjú mintákat egyenként ismeretlenként tekintettük, majd a többi mintából szerkesztett kalibrációs görbéről a koncentrációjukat visszaolvastuk. A 4-5. táblázat bemutatja az így 
kapott analitikai eredményeket, az ICP-AES mérések eredményeit és a minták nominális összetételét.


4-22. ábra: Forrasztófémekben, ónra és ólomra felvett MP-LIBS „klasszikus” kalibrációs görbék. A hibasávok 5 ismételt mérésből adódó szórásadatok.

\begin{tabular}{cccccc}
\hline \hline Speciesz & $\boldsymbol{\lambda}(\mathbf{n m})$ & LOD (\%) & $\begin{array}{c}\text { Nominális } \\
\text { koncentráció }\end{array}$ & $\begin{array}{c}\text { LIBS } \\
\text { koncentráció }\end{array}$ & $\begin{array}{c}\text { ICP-AES } \\
\text { koncentráció } \\
\mathbf{( \% )}\end{array}$ \\
\hline \multirow{2}{*}{$\mathrm{Pb}(\mathrm{I})$} & \multirow{2}{*}{364,0} & \multirow{2}{*}{1,16} & 60 & 67,9 & 53,0 \\
& & & 70 & 73,8 & 61,1 \\
$\mathrm{Sn}(\mathrm{I})$ & \multirow{2}{*}{270,7} & \multirow{2}{*}{1,12} & 30 & 33,7 & 30,8 \\
& & 40 & 39,4 & 39,8 \\
\hline \hline
\end{tabular}

4-5. táblázat: A 4-22. ábrán bemutatott kalibrációs görbék alapján számított eredmények, amelyek öt ismételt mérésből származnak.

Az eredményekről elmondható, hogy a LIBS módszerrel kapott adatok pontossága semmiben nem marad el az ICP-AES adatokétól. Ón esetében a kétféle módszerrel kapott analíziseredmények jól egyeznek egymással (az eltérés előjele is azonos). Az adatok egyezése a nominális összetétellel - ami természetesen a vett kis mintamenynyiség miatt csak közelítő pontosságú - is egészen jó. Az ólom eredményekben látunk jelentősebb eltérést (kb. 10\%); itt viszont mindkét módszer eredményei jelentősebben eltérnek a nominális összetételtől. Ennek oka a minták eltérő mértékű inhomogenitása is lehet ólomra nézve, de a LIBS esetében a kevésbé megbízható kalibráció (az egyik vizsgált forrasztófém ólommentes összetétel volt) is szerepet játszik.

Összefoglalóan tehát elmondható, hogy az MP-LIBS módszer egy gyors, megfelelően pontos módszernek ígérkezik forrasztófém ötvözetek összetételének ellenőrzésére. Pár százalékos, az oldatos módszerrel összevethető pontosságú kvantitatív in- 
formáció nyerhető igen kis mennyiségű ( $k b .10 \mu \mathrm{g}$ ) mintából, mindössze pár perc alatt, csekély energia és vegyszer ráfordítása mellett.

\subsubsection{Jelnormalizációs eljárás alkalmazása}

Ahogyan azt már korábban leírtam, a LIBS jelintenzitást számos kísérleti paraméter befolyásolja és ezek hatásának korrekcióba vételére többféle jelnormalizációs módszert is kidolgoztak már a kutatók [195].

Egy, főként az elemeloszlás vizsgálatokat befolyásoló ide vonatkozó jelbefolyásoló tényező a lencse-minta távolság. Ha mintánk nem tökéletesen síkszerü, illetve ha annak alsó és felső lapja nem teljesen párhuzamos, akkor a tárgyasztalon való transzláció során a lencse-minta távolság lövésről-lövésre változik. Rövid fókusztávolságú gyűjtőlencse(rendszer) alkalmazása esetén a minta ilyenkor könnyen kimozdul a fókuszpontból és a jelintenzitás ennek következtében megváltozik. Ez a probléma főként metszetek elemeloszlás-vizsgálatakor jelentkezik. Ennek kiküszöbölésére alkalmas optikai megoldás, ha a LIBS rendszer autofókusz optikát tartalmaz (1.2.2. fejezet), azonban ez bonyolult és viszonylag költséges megoldás. Egy másik, költséghatékonyabb megoldás valamilyen jelnormalizációs technika alkalmazása. Kísérleteink során mi ez utóbbi lehetőséggel foglalkoztunk.

A nettó intenzitás (NI) ingadozásának kiküszöbölésére a spektrum teljes integrált hátterével (TIB) való normálás módszerét teszteltük. A mérésekhez a síklap alakú tiszta fém mintákat (ón és cink) egyik végüknél enyhén alátámasztva ragasztottuk fel. A lövések között a mikroszkóp tárgyasztalának skáláját felhasználva 1-1 mm-rel eltoltuk a mintát, így változtatva lövésről-lövésre a lencse-minta távolságot. A kísérletek során egy impulzussal dolgoztunk. Előzetes eredményeink a 4-23. ábrán láthatók.
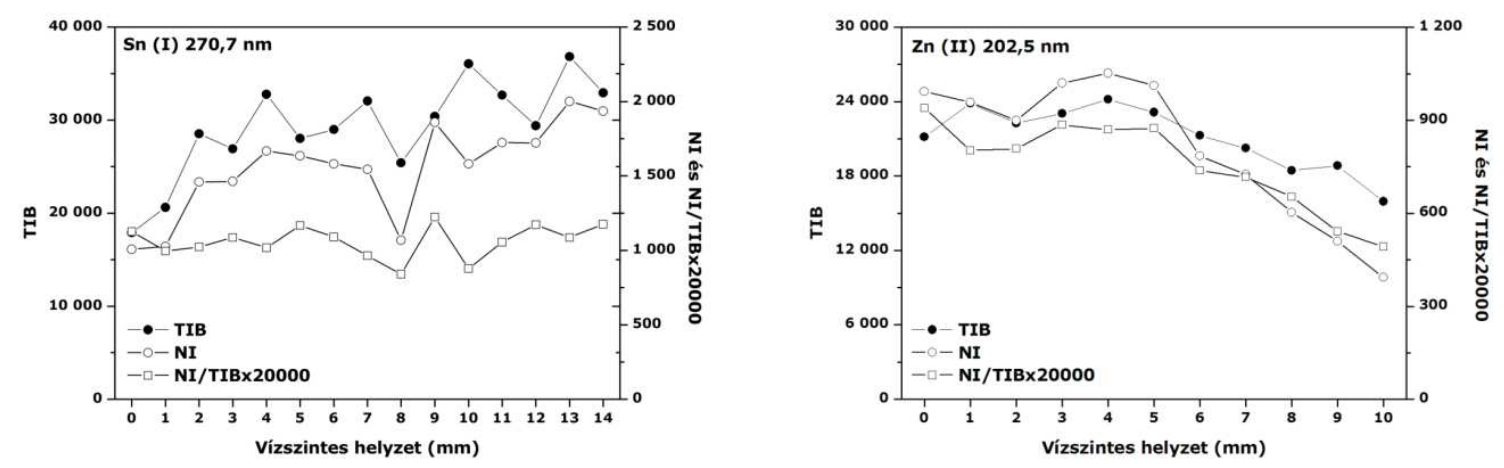

4-23. ábra: A nettó (NI) és a teljes integrált háttér (TIB) intenzitás, valamint a teljes integrált háttérintenzitással normált nettó intenzitás (NI/TIB) változása

a lencse-minta távolság változásának függvényében. 
Az NI görbék a várt módon valóban arról tanúskodnak, hogy a minták kimozdultak a transzláció során a fókuszfoltból; az NI görbék határozott monoton csökkenő, illetve növekvő jelleget mutatnak. Az NI és a TIB görbe lefutása valóban hasonló, vagyis a TIB érték a normalizációra alkalmazhatónak tünik. Az ón esetében az NI/TIB görbe valóban közel konstans (átlagos meredeksége közel nulla). A cink esetében az NI/TIB görbe szintén kisebb meredekségü, mint a korrekció nélküli NI görbe, azonban a korrekció itt kisebb hatékonyságúnak bizonyult. Egy másik megfigyelésünk, ami az eltérő viselkedés egyik oka is lehet, hogy ahogy azonos irányban távolodtunk a fókuszfolttól, a Zn ionvonalának intenzitása csökkenő, az Sn atomvonalának intenzitása pedig növekvő trendet mutatott. Elképzelésünk szerint a magyarázat, amennyiben a megfigyelést későbbi kísérleteink is alátámasztják majd, az lehet, hogy a kimozdulás hatására bekövetkező ellenkező irányú intenzitásváltozás a plazmahőmérsékletnek az elem neutrális atomjainak és ionjainak koncentrációjára kifejtett ellenkező irányú hatásából származik.

Az ábrán az is jól látszik, hogy az intenzitásadatok szórása viszonylag jelentős, melynek legkézenfekvőbb oka az, hogy a méréseknél csak egy impulzussal dolgoztunk (SP-LIBS). A módszer több impulzusra (MP-LIBS) is könnyen kiterjeszthetö, amivel várhatóan jelentősen jobb szórás érhető el. Ezen kísérleteink jelenleg is folyamatban vannak.

\subsection{4. Összefoglalás}

Ebben a fejezetben ötvözetek kvantitatív elemzésével, illetve egy jelkorrekciós eljárás tesztelésével foglalkoztunk. A LIBS-szel történő analitikai mérések itt is megtapasztalt előnyei közé sorolhatjuk a gyorsaságot, a minimális mintaigényt és azt, hogy nincs szükség a minták összetételének előzetes ismeretére. Az ötvözőelemek minőségéről szükséges előzetes információ egyetlen spektrum felvételével megszerezhető.

Aranyötvözetek esetében az elért pontosság a szabványos módszer pontosságával vetekszik, ezért úgy hisszük, hogy az MP-LIBS hosszú távon akár a körülményes tűzipróba módszerének alternatívájává válhat. Módszerünk fentebb ismertetett tulajdonságaira alapozva és az aranyötvözetek előállításáról rendelkezésünkre álló információk ismeretében a javasolt módszerrel történő elemzés a következőképpen képzelhető el. Az első, előkészítő lépésben a GLCM-LIBS kalibrációs görbéket kell meghatározni és elraktározni mindegyik ötvözőelem kombinációra, az elemek érzékeny és spektrális zavarástól mentes vonalainak figyelembe vételével. Ez a lépés könnyen megvalósítható, mivel ötvözőként nem túl sok elemet alkalmaznak az aranyiparban. A 
következő lépésben az ötvözők minősége minden ismeretlen minta esetében egyetlen spektrumból megállapítható. Ezen ismeretek alapján a minták csoportosíthatók és végül a megfelelő, már elraktározott GLCM-LIBS kalibrációs görbe segítségével az aranytartalom meghatározható. Számítógépesített adatkiértékeléssel az egész procedúra néhány percet vesz igénybe.

Megmutattuk azt is, hogy az MP-LIBS módszer forrasztófém ötvözetek összetételének gyors és az oldatos módszerekkel (ICP-AES) összemérhető pontosságú ellenőrzésére is megfelelő kellően érzékeny spektrométer alkalmazásával. Ez a módszert akár ROHS megfelelőség vizsgálatára vagy akár elektronikai hulladékok automatikus válogatása, feldolgozása során való alkalmazásra is alkalmassá teszi.

Végezetül előzetes kísérleti eredményeink azt mutatták, hogy az emissziós spektrum integrált háttérjelén (TIB) alapuló jelkorrekció a vonalintenzitások egyes, másképpen körülményesen kezelhető „drift"-je esetén (pl. egyenetlen mintafelszín) jól alkalmazható. 


\section{5. Összefoglalás}

Doktori munkám során a kolineáris, többimpulzusos lézer indukált plazmák jellemzésével és atomspektroszkópiai alkalmazásával foglalkoztam.

Az 1-4. és 1-5. fejezetben leírt módon, a többszörös lézerimpulzussal történő plazmakeltés módszerével jelentős teljesítőképesség növekedés érhető el a LIBS spektrometriában az SP-LIBS esethez képest. Ezt a jelenséget 2000 óta már számos tanulmány meggyőzően dokumentálta, elsősorban a technikailag könnyebben tanulmányozható/megvalósítható kétimpulzusos esetre vonatkozóan (DP-LIBS). Mindennek ellenére azonban még mindig nem teljesen tisztázott, hogy milyen részfolyamatok okozzák, illetve járulnak hozzá az analitikai teljesítőképesség nagymértékű javulásához; a szakirodalomban eltérő, némely esetben egymásnak ellentmondó megállapítások és elméletek olvashatók erre vonatkozóan.

$A z$ elmondottak különösen érvényesek a kettőnél több lézerimpulzussal kivitelezett LIBS spektrometria (MP-LIBS) esetére. Az irodalomban ugyanis még nagyon kevés kísérleti adat található a kolineáris MP-LIB plazmákra és analitikai alkalmazásukra vonatkozóan, noha ezek az adatok igen ígéretesek. Ezen okok miatt ezért kísérleti munkám egy részét a jelnövekedésért felelős mechanizmusok feltérképezése tette ki.

1. Tanulmányoztam a több, időben egymást gyorsan követő ( $<50 \mu \mathrm{s})$ kolineáris lézerimpulzussal szilárd minták felületén létrehozott letörési plazmák ablációs jellemzőit, időbeli és térbeli fejlődését és azonosítottam az MP-LIBS jelnövekedésért felelős főbb folyamatokat.

1.a. Tiszta rézben, valamint fémbevonattal ellátott ötvözetekben létrehozott ablációs kráterek profilometriás és mikroszkópiás vizsgálata révén megállapítottam, hogy a kolineáris lézerimpulzusok által okozott ablációs folyamatok között kölcsönhatás áll fenn; az ablációs mélység (ablációs ráta) az impulzusszámmal a lineárisnál nagyobb rendben nő. Az ablált anyagmennyiséget például négytagú impulzussorozat esetén közel hatszorosnak találtam az azonos öszszes számú önálló impulzus által okozottnál. Vonatkozó további eredményeim és irodalmi információk alapján az ablált anyagmennyiség növekedésének valószínű oka az ablációs küszöb csökkenése a mintafelület előmelegedése és az impulzussorozaton belüli korai impulzusok által a mintafelület felett létrehozott 
csökkent nyomású zóna okozta erősebb párolgás.

1.b. Tanulmányoztam a kolineáris MP-LIB plazmák időbeli és térbeli fejlődését és hőmérsékletét nagy időfelbontású kamera és spektrográf segítségével. Megállapítottam, hogy az első lézerimpulzus által keltett plazma kisebb fényességü, jelentősen kisebb maximális térfogatú, kisebb lineáris terjedési sebességű és kb. fele olyan élettartamú, mint a követő impulzusok által keltett plazmák vonatkozó adata. Az MP-LIB plazmák alakja megfelel az atmoszférikus SP-LIB plazmák függőlegesen kissé megnyúlt, alapvetően gömbszerü alakjának. Az MP-LIB plazmák hőmérsékletét is meghatároztam Saha-Boltzmann módszer és Mg ionvonalak intenzitásának alkalmazásával és azokat 20000-25000 K értékűnek találtam. Eredményeim azt mutatták, hogy a később érkező lézerimpulzusok a második impulzus kivételével nem képesek magasabb hőmérsékletre hevíteni a plazmát, mint az első.

1.c. $\mathrm{Si}, \mathrm{Zn}$, Cu és $\mathrm{Al}$ mintákon keltett MP-LIB plazmák által sugárzott vonalas és folytonos emisszió időbeli lefolyásának tanulmányozása során kapott eredményeim azt mutatják, hogy a nagy gerjesztési energiájú vonalak emissziója az integrált spektrális háttérhez hasonlóan időben lépcsőzetes lefutású, míg a kis gerjesztési energiájú (főként neutrális specieszektől származó) vonalak emissziója kimondottan lassú lecsengésű, akár ms időtartamú is lehet. Megmutattam, hogy a lépcsőzetes emissziós görbék időlépcsői egybeesnek a lézerimpulzusok követési idejével. Mindez arra enged következtetni, hogy a nagy gerjesztési energiájú specieszek gerjesztése számára az MP-LIB plazma csak azon rövid időszakokban biztosít kedvező környezetet, amikor az újabb lézerimpulzus újrahevíti a plazmát és a plazmahőmérséklet a lehető legmagasabb.

1.d. Fenti eredményeim révén először sikerült kísérleti bizonyítékokat szolgáltatnom arra, hogy az időben integráló detektálást alkalmazó kolineáris MP-LIBS spektroszkópiában reprodukálhatóan tapasztalható jelentős jelnövekedés főként két folyamat hatásának tulajdonítható. Az egyik, meghatározó folyamat a követő lézerimpulzusok által okozott ismételt abláció, ami nagyobb összes ablált anyagmennyiséggel jár. A másik folyamat a plazma újrahevítése és így a plazmabeli specieszek újragerjesztése a követő lézerimpulzusok által.

A többszörös lézerimpulzusokkal történő gerjesztés hatására a fontosabb teljesítményjellemzőkben ( $p l$. érzékenység, ismételhetőség) bekövetkező, reprodukálhatóan tapasztalt javulás arra inspirált minket, hogy munkánk következő lépése az MP- 
LIBS módszer analitikai teljesítőképességének részletes és szisztematikus vizsgálata legyen.

2. Analitikai tisztaságú $\mathrm{Al}, \mathrm{Cu}, \mathrm{Mg}, \mathrm{Si}$ és $\mathrm{Zn}$, valamint acél, arany és ón-ólom ötvözetek, továbbá pirolitikus szén és PTFE minták felhasználásával, több mint 20 spektrumvonal esetére vonatkozóan részletesen felmértem a térbeli és időbeli integrálást alkalmazó, kolineáris MP-LIBS spektrometria analitikai teljesítményjellemzőit és kísérleti magyarázatot adtam az SP-LIBS esethez képest tapasztalt javulás okaira nézve.

2.a. A nettó és az impulzusszámmal (energiával) normalizált nettó jelintenzitás változását vizsgáltam az egy lövésen belüli impulzusszám függvényében fém, polimer és grafit mintákon. Az atomvonalak esetében megállapítottam, hogy mind a nettó, mind az energiával normalizált nettó intenzitás növekszik az impulzusszám növelésével. Az ionvonalak vizsgálata során eltérő viselkedést tapasztaltam; egyes vonalak (pl. a Mg (II) 448,1 nm és a Si (II) 412,8 nm) hasonlóan viselkedtek, mint az atomvonalak, más ionvonalaknál (pl. Au (II) 312,7 nm és Al (II) 422,7 nm) azonban a normalizált intenzitásgörbék gyakorlatilag nem mutattak növekedést az impulzusszám növelésével. Eszerint ezeknél a magas gerjesztési energiával rendelkező vonalaknál minden egyes lézerimpulzus hasonló vagy csak kismértékben növekvő jelintenzitást produkál. Nagyszámú adat összehasonlításával megállapítottam, hogy kísérleti MP-LIBS rendszerünk és hat lézerimpulzus alkalmazásával a maximális jelnövekedés az 5-7 eV gerjesztési energiájú vonalaknál tapasztalható. Megmutattam, hogy az egyes lézerimpulzusok által generált háttér rövid élettartamú és a hozzájárulása az integrált vonalintenzitáshoz a második impulzustól kezdve ugyanaz, vagyis időben integrált intenzitásadatok gyűjtése nem rontja a jel/háttér viszonyt.

2.b. Kísérleti úton tanulmányoztam, hogyan viselkedik egy elem adott spektrumvonalának nettó intenzitása az impulzusszám függvényében, ha az elem különböző mintamátrixban található. Azt tapasztaltam, hogy a mátrix hatása viszonylag csekély az intenzitásgörbéknek az impulzusszám függvényében mutatott lefutására, azonban a relatív nettó jelnövekedés értéke egy adott impulzusszámnál ugyanarra a spektrumvonalra különböző mátrixokban eltérő.

2.c. Megmutattam, hogy az ismételhetőség nagymértékben javul, ha növeljük az egy lövésen belüli lézerimpulzusok számát. Lövésenként hat impulzus alkalmazásával a nettó intenzitásadatok szórása 5\% körülire csökkent. Ez az 
adat az SP-LIBS jelek ismételhetőségével összehasonlítva többszörös javulást jelent.

2.d. Megállapítottam, hogy az MP-LIBS kalibrációs görbék lineáris dinamikus tartománya jóval szélesebb, mint az SP-LIBS, vagy akár a DP-LIBS kalibrációs görbéké. Az SP-LIBS kalibrációs görbék lineáris tartományának felső határát korlátozó önabszorpció hatása az MP-LIBS esetben igen kismértékű, a kalibrációs görbék több tíz százalék koncentrációig jó linearitást mutatnak.

2.e. Kimutattam, hogy a csökkenő szórás (javuló ismételhetőség) és a növekvő érzékenység (megnövekedett vonalintenzitások) együttes következményeként a kimutatási határok jelentős javulást mutatnak. Kísérleti elrendezésünkben a vizsgált elemek és spektrumvonalak esetében az MP-LIBS kimutatási értékek 4,2-16,7-szeres javulást mutattak a DP-LIBS értékekhez képest.

Kutatócsoportunk 2001-ben ötvözetek elemzésére egy új, a lineáris korreláción alapuló kalibrációs módszert (általánosított lineáris korrelációs kalibráció, GLCM) vezetett be (1.3.2.4. fejezet). Látva az MP-LIBS teljesítményjellemzőit, célul tűztük ki magunk elé, hogy megvizsgáljuk, lehetséges-e a módszer és a GLCM kombinálásával aranyötvözetek elemzésében a tűzipróbához hasonló pontosságot és precizitást elérni (ideális körülmények között 0.1-0.5\%o).

3.a. Módszert dolgoztam ki az MP-LIBS spektrometria kvantitatív analitikai alkalmazására ötvözetek pontos koncentrációjának meghatározása céljából. Megmutattam, hogy a kísérleti paraméterek megfelelő optimálásával, a fejlett GLCM kalibrációs módszer alkalmazásával és a kolineáris MP-LIBS spektrometria javult teljesítményjellemzői kihasználásával aranyötvözetek összetétele meghatározható olyan pontossággal és precizitással, ami öszszemérhető a standardizált tűzipróba teljesítőképességével. Eredményeim mérési hibája és precizitása mindössze néhány ezrelék volt.

További sikeres kísérleteket is végeztem, amelyek célja ón-ólom ötvözetek elemi összetételének kvantitatív meghatározása volt, valamint teszteltem egy jelnormalizációs (a teljes integrált háttéremisszión alapuló) módszer alkalmasságát az ismételhetőség javítására. 


\section{Summary}

In my doctoral work, I studied the characteristics of multi-pulse laser induced plasmas and assessed the analytical performance of multi-pulse laser induced breakdown spectroscopy (MP-LIBS).

The use of two or more laser impulses in laser-induced breakdown spectroscopy results in significantly improved analytical figures of merit. Several studies in the post2000 literature documented this phenomenon convincingly, mostly in the technically easy-to-realize double-pulse LIBS (DP-LIBS) scenario. However, it is not yet conclusively clarified yet, what fundamental processes are responsible for or contribute to the improvement of analytical performance. Contradicting observations and theories can also be found on the matter in the literature, which is so partly because LIBS setups used in studies are slightly different, and experimental conditions are known to have a significant effect on the processes taking place in the high temperature and very transient environment of LIB plasmas.

The above said things especially apply to collinear MP-LIBS, where plasma processes are even more complicated. Collinear MP-LIBS studies are also scarce in the literature, although the published data are generally very promising. Based on this, the aim of my doctoral work to experimentally examine the characteristics of MP-LIB plasmas induced by collinear laser impulses and to assess the analytical performance of the MP-LIBS method.

1. I studied the ablation characteristics, temporal and spatial evolution of breakdown plasmas induced on solid samples by multiple collinear laser pulses (interpulse time delay: $<50 \mu \mathrm{s}$, pulse duration: $\approx 10 \mathrm{~ns}$ ) in order to identify the primary processes responsible for the signal enhancement in MP-LIBS.

1.a. By means of profilometric and microscopic examination of ablation craters produced in pure copper and galvanized alloys I established that an interaction exists between the ablation processes induced by collinear laser pulses. The increase of the ablation depth with the number of pulses was found to be stronger than linear; for example, the amount of the material ablated by a four-pulse burst was found to be six times greater than that ablated by the same number of single pulses. Based on my results and literature data, the increase of the ablated material can be 
attributed to the decrease of the ablation threshold due to the preheating of the sample surface and/or the lower pressure zone above the sample surface produced by earlier pulses within the burst.

1.b. I studied the temporal and spatial evolution of collinear MP-LIB plasmas and I established, that the luminosity, the maximum volume and the linear expansion rate of the plasma induced by the first laser pulse are lower than relevant data for later coming pulses and the SP-LIB plasma lifetime is the half. The shape of MP-LIB plasmas is similar to the shape of SP-LIB plasmas: it is basically globular with some elongation in the vertical direction. I also determined the temperature of MP-LIB plasmas using Saha-Boltzmann method and the intensity of $\mathrm{Mg}$ ionic lines and I found it to be $20000-25000 \mathrm{~K}$. The results indicate that the later coming pulses, with the exception of the second pulse, are not able to heat the plasma to a higher temperature than former pulses.

1.c. I studied the temporal course of line and continuum emission by MP-LIB plasmas induced on $\mathrm{Si}, \mathrm{Zn}, \mathrm{Cu}$ and $\mathrm{Al}$ targets. The emission from spectral lines with high excitation potential and integrated background emission was found to be stepwise in time, while the emission from spectral lines with lower excitation energy (originating mainly from neutral species) ring off very slowly, with a duration of sometimes as much as several ms. I established that the time steps of the stepwise emission curves concide with the interpulse time delays. These results suggest that for the excitation of species with high excitation energy, the conditions are only favorable for the short time in the lifetime of an MP-LIB plasma when a laser pulse rekindles the plasma and its temperature is the highest.

1.d. Based on the above presented results, I provided experimental evidence that the reproducible significant signal enhancement in collinear MP-LIBS spectroscopy with time integrated detection is mainly due to the effect of two mechanisms. The determining mechanism is the repetitive ablation caused by sequential laser pulses, which results in a higher total ablated mass, also increased by the decrease of the ablation threshold. The other mechanism is plasma reheating and the re-excitation of plasma species by sequential laser pulses. 
The application of collinear multiple laser pulses resulted in a reproducible improvement in the major analytical performance figures (e.g. sensitivity, repeatibility) of LIBS. Inspired by these findings, a detailed and systematic examination of analytical performance of MP-LIBS spectroscopy was also carried out.

2. I investigated the analytical performance of collinear MP-LIBS spectrometry using time and spatially integrated detection in detail by using analytical purity $\mathrm{Al}, \mathrm{Cu}, \mathrm{Mg}, \mathrm{Si}$ and $\mathrm{Zn}$, as well as steel, gold and tin-lead alloy, pyrolithic graphite and PTFE samples and more than 20 spectral lines.

2.a. I studied the net and the pulse number (energy) normalized net signal intensity as a function of the number of pulses in a burst in metallic, polymer and graphite samples. In case of atomic spectral lines I established, that both the net and the energy normalized net intensities increase with the increase of the number of pulses. For ionic lines I found a different behavior; some lines (e.g. Mg (II) $448.1 \mathrm{~nm}$ and Si (II) 412.8 $\mathrm{nm}$ ) behave analogously to neutral lines, but in case of other ionic lines (e.g. Au (II) $312.7 \mathrm{~nm}$ and Al (II) $422.7 \mathrm{~nm}$ ) the normalized intensity curves are practically constant. This indicates that the net signal intensity for these lines which originate from high-lying excited levels, generated by each pulse is similar or increases only slightly. I established from numerous data, that using our experimental MP-LIBS system and six laser pulses the maximum signal enhancement can be found at spectral lines with 5-7 eV excitation potential. I showed, that the background signal generated by each pulse in the burst is short lived and its contribution is about the same from the second pulse on, hence the use of time integrated spectral data acquisiton does not worsen the S/B ratio.

2.b. I experimentally studied the behavior of the net intensity of spectral lines of the same element in different matrices as a function of the number of laser pulses. I found that the influence of matrix is relatively low on the shape of intensity curves as a function of the number of pulses, however the relative net signal enhancement with the same pulse number is different for the same spectral line in different matrices.

2.c. I showed that the repeatability improves significantly with an increase of the number of pulses in a burst. Using six pulses in a burst, the relative standard deviation on net intensities drops down to about $5 \%$. This value means a multiple-time improvement compared to the repeatibility of SPLIBS signals. 
2.d. I established that the linear dynamic range of MP-LIBS calibration curves is much wider than SP- or DP-LIBS calibration curves. The effect of self absorption - which restricts the upper concentration limit of the linear dynamic range for SP-LIBS - is advantageously suppressed, and the calibration curves show good linearity up to tens of percents concentration.

2.e. I demonstrated, that as a combined consequence of the improved repeatability and increased sensitivity is a significant improvement of the limits of detection. In our experimental system and for the studied spectral lines, MP-LIBS LOD data were 4.2-16.7 times better than DP-LIBS data.

In 2001, our research group introduced a new calibration method based on linear correlation (generalized linear correlation method, GLCM) for analysis of alloys. Based on the above results, we also decided to investigate it whether it is feasible to perform quantitative analysis of gold alloys with an accuracy and precision comparable to that of the cupellation method (under ideal conditions $0.1-0.5 \%$ ) using MP-LIBS combined with GLCM.

3.a. An analytical method was worked out for the accurate determination of the accurate composition of gold alloys. After a careful optimization of experimental parameters, using the advanced GLCM calibration method and by exploiting the improved analytical performances provided by collinear MP-LIBS it is feasible to perform a quantitative analysis of gold alloys with an accuracy and precision comparable to that of the cupellation method. The error and the precision of my results were only a few \%o.

In addition to the above, further successful analytical experiments were also carried out that aimed at the quantitative determination of the elemental composition of lead-tin alloys and at testing the potential of a signal normalization approach (based on the total integrated background emission) in improving the signal repeatability. 


\section{Irodalomjegyzék}

[1] J.M. Vadillo, J.J. Laserna, Spectrochimica Acta Part B, 2004, 59, 147.

[2] C. Pasquini, J. Cortez, L.M.C. Silva, F.B. Gonzaga, Journal of the Brazilian Chemical Society, 2007, 18, 3, 463.

[3] D.A. Rusak, B.C. Castle, B.W. Smith, J.D. Winefordner, Critical Reviews in Analytical Chemistry, 1997, 27, 4, 257.

[4] D.A. Rusak, B.C. Castle, B.W. Smith, J.D. Winefordner, Trends in Analytical Chemistry, 1998, 17, 453.

[5] L.J. Radziemski, Spectrochimica Acta Part B, 2002, 57, 1109.

[6] D.A. Cremers, L.J. Radziemski: Handbook of laser-induced breakdown spectroscopy, John Wiley \& Sons Ltd, 2006.

[7] A. Einstein, Physikalische Zeitschrift, 1917, 18, 121.

[8] T.H. Maiman, Nature, 1960, 187, 493.

[9] F. Brech, L. Cross, Applied Spectroscopy, 1962, 16, 59.

[10] J. Debras-Guédon, N. Liodec, Comptes Rendus de l'Académie des sciences, 1963, 257, 3336.

[11] E.F. Runge, R.W. Minck, F.R. Bryan, Spectrochimica Acta, 1964, 20, 733.

[12] L. Moenke-Blankenburg: Laser Micro Analysis, John Wiley \& Sons Ltd, 1989.

[13] K.W. Marich, P.W. Carr, W.J. Treytl, D. Glick, Analytical Chemistry, 1970, 42, 1775.

[14] R.H. Scott, A. Strasheim, Spectrochimica Acta Part B, 1970, 25, 311.

[15] L.J. Radziemski, D.A. Cremers, T.R. Loree, Spectrochimica Acta Part B, 1983, $38,349$.

[16] L.J. Radziemski, T.R. Loree, D.A. Cremers, N.M. Hoffman, Analytical Chemistry, 1983, 55, 1246.

[17] D.A. Cremers, L.J. Radziemski, Analytical Chemistry, 1983, 55, 1252.

[18] L.J. Radziemski, D.A. Cremers (Eds): Laser-induced plasmas and applications, Marcel Dekker, 1989. 
[19] L.J. Radziemski, Microchemical Journal, 1994, 50, 218.

[20] D.A. Cremers, Applied Spectroscopy, 1987, 41, 572.

[21] C.M. Davies, H.H. Telle, D.J. Montgomery, R.E. Corbett, Spectrochimica Acta Part B, 1995, 50, 1059.

[22] B.J. Marquardt, S.R. Goode, S.M. Angel, Analytical Cemistry, 1996, 68, 977.

[23] A.K. Knight, D.A. Cremers, M.J. Ferris, N.L. Scherbarth, R.C. Wiens, J.D. Blacic, W.M. Calvin, J.E. Nordholt, 1999, 5th Int'l. Conf. On Mars, 6064, The Lunar \& Planetary Science Institute, Houston, TX.

[24] A. Ciucci, M. Corsi, V. Palleschi, S. Rastelli, A. Salvetti, E. Tognoni, Applied Spectroscopy, 1999, 53, 960.

[25] D.A. Cremers, M.J. Ferris, M. Davies, International Society for Optics and Photonics (SPIE), 1996, 2835, 190.

[26] K.Y. Yamamoto, D.A. Cremers, M.J. Ferris, L.E. Foster, Applied Spectroscopy, 1996, 50, 222.

[27] W.W. Duley: Laser processing and analysis of materials, Plenum Press, 1983.

[28] P.J. Elving, J.D. Winefordner, I.M. Kolthoff: Chemical analysis, John Wiley \& Sons Ltd, 50.

[29] O. Svelto: Principles of lasers, Springer, 2004.

[30] Gy. Záray: Az elemanalitika korszerű módszerei, Akadémiai Kiadó, 2006.

[31] I.B. Gornushkin, K. Amponsah-Manager, B.W. Smith, N. Omenetto, J.D. Winefordner, Applied Spectroscopy, 2004, 58, 762.

[32] A.S. Eppler, D.A. Cremers, D.D. Hickmott, M.J. Ferris, A.C. Koskelo, Applied Spectroscopy, 1996, 50, 1175.

[33] C. Chaléard, P. Mauchien, N. Andre, J. Übbing, J.L. Lacour, C.J. Geertsen, Journal of Analytical Atomic Spectrometry, 1997, 12, 183.

[34] P. Fichet, P. Mauchien, J.F. Wagner, C. Moulin, Analytica Chimica Acta, 2001, 429, 269.

[35] G. Galbács, V. Budavári, Zs. Geretovszky, Journal of Analytical Atomic Spectrometry, 2005, 2, 974.

[36] C. Aragon, J.A. Aguilera, F. Penalba, Applied Spectroscopy, 1999, 53, 1259.

[37] G. Galbács, N. Jedlinszki, K. Herrera, N. Omenetto, B.W. Smith, J.D. Winefordner, Applied Spectroscopy, 2010, 64, 161. 
[38] R. Barbini, F. Colao, R. Fantoni, A. Palucci, S. Ribezzo, H.J.L. van der Steen, M. Angelone, Applied Physics B, 1997, 65, 101.

[39] B.J. Marquardt, D.N. Stratis, D.A. Cremers, S.M. Angel, Applied Spectroscopy, 1998, 52, 1148.

[40] R.E. Neuhauser, U. Panne, R. Niessner, Analytica Chimica Acta, 1999, 392, 47.

[41] A.I. Whitehouse, J. Young, I.M. Botheroyd, S. Lawson, C.P. Evans, J. Wright, Spectrochimica Acta Part B, 2001, 56, 821.

[42] A.K. Rai, H.S. Zhang, F.Y. Yueh, J.P. Singh, A. Weisburg, Spectrochimica Acta Part B, 2001,56, 2371.

[43] R. Krasniker, V. Bulatov, I. Schechter, Spectrochimica Acta Part B, 2001, 56, 609.

[44] A.K. Knight, N.L. Scherbarth, D.A. Cremers, M.J. Ferris, Applied Spectroscopy, 2000, 54, 331.

[45] A.W. Miziolek, V. Palleschi, I. Schechter: Laser-induced breakdown spectroscopy: fundamentals and applications, Cambridge University Press, 2006.

[46] B.S. Luk'yanchuk, W. Marine, S.I. Anisimov, Laser Physics, 1998, 8, 291.

[47] J. Koch, H. Lindner, A. von Bohlen, R. Hergenroder, K. Niemax, Journal of Analytical Atomic Spectrometry, 2005, 20, 901.

[48] C.Y. Liu, X.L. Mao, J. Gonzalez, R.E. Russo, Journal of Analytical Atomic Spectrometry, 2005, 20, 200.

[49] X.L. Mao, A.C. Ciocan, O.V. Borisov, R.E. Russo, Applied Surface Science, 1998, 127-129, 262.

[50] H.C. Liu, X.L. Mao, J.H. Yoo, R.E. Russo, Applied Physics Letters, 1999, 75, 1216.

[51] D. von der Linde, K. Sokolowski-Tinten, Applied Surface Science, 2000, 154, 1.

[52] X. Mao, R.E. Russo, Applied Physics A, 1997, 64, 1.

[53] X.L. Mao, W.T. Chan, R.E. Russo, Applied Spectroscopy, 1997, 51, 1047.

[54] O.V. Borisov, X.L. Mao, A.C. Ciocan, R.E. Russo, Applied Surface Science, 1998, 127-129, 315.

[55] K.L. Eland, D.N. Stratis, D.M. Gold, S.R. Goode, S.M. Angel, Applied Spectroscopy, 2001, 55, 286. 
[56] X. Zeng, X.L. Mao, R. Greif, R.E. Russo, Applied Physics A, 2005, 80, 237.

[57] L. St-Onge, M. Sabsabi, P. Cielo, Spectrochimica Acta Part B, 1998, 53, 407.

[58] F. Colao, V. Lazic, R. Fantoni, S. Pershin, Spectrochimica Acta Part B, 2002, $57,1167$.

[59] G. Abdellatif, H. Imam, Spectrochimica Acta Part B, 2002, 57, 1155.

[60] B.N. Chichkov, C. Momma, S. Nolte, F. von Alvensleben, A. Tunnermann, Applied Physics A, 1996, 63, 109.

[61] B. Le Drogoff, J. Margot, M. Chaker, M. Sabsabi, O. Barthélemy, T.W. Johnston, S. Laville, F. Vidal, Y. von Kaenel, Spectrochimica Acta Part B, 2001, 56, 987.

[62] J.-B. Sirven, B. Bousquet, L. Canioni, L. Sarger, Spectrochimica Acta Part B, 2004, 59, 1033.

[63] I. Horn, M. Guillong, D. Günther, Applied Surface Science, 2001, 182, 91.

[64] L.M. Cabalin, J. Laserna, Spectrochimica Acta B, 1998, 53, 723.

[65] X. Mao, W.T. Chan, M. Caetano, M.A. Shannon, R.E. Russo, Applied Surface Science, 1996, 96-98, 126.

[66] J.A. Aguilera, C. Aragon, F. Penalba, Applied Surface Science, 1998, 127-129, 309.

[67] A. Bogaerts, Z.Chen, Journal of Analytical Atomic Spectrometry, 2004, 19, 1169.

[68] S.S. Harilal, C.V. Bindhu, V.P.N. Nampoori, C.P.G. Vallabhan, Applied Physics Letters, 1998, 72, 167.

[69] S. Amoruso, B. Toftmann, J. Schou, Applied Physics A, 2004, 79, 1311.

[70] R.E. Russo, X.L Mao, M. Caetano, M.A. Shannon, Applied Surface Science, 1996, 96-98, 144.

[71] G. Cristoforetti, S. Legnaioli, V. Palleschi, A. Salvetti, E. Tognoni, Spectrochimica Acta Part B, 2004, 59, 1907.

[71] A.E. Pichahchy, D.A. Cremers, M.J. Ferris, Spectrochimica Acta Part B, 1997, $52,25$.

[72] D.C.S. Beddows, O. Samek, M. Lizka, H.H. Telle, Spectrochimica Acta Part B, 2002, 57, 1461.

[73] R. Nyga, W. Neu, Optics Letters, 1993, 18, 747. 
[74] D.E. Kim, K.J. Yoo, H.K. Park, K.J. Oh, D.W. Kim, Applied Spectroscopy, 1997, $51,22$.

[75] R. Wisbrun, I. Schechter, R. Niessner, H. Schröder, K.L. Kompa, Analytical Chemistry, 1994, 66, 2964.

[76] W. Sdorra, K. Niemax, Mikrochimica Acta, 1992, 107, 319.

[77] L. Radziemski, D.A. Cremers, K. Benelli, C. Khoo, R.D. Harris, Spectrochimica Acta Part B, 2005, 60, 237.

[78] Y. Iida, Spectrochimica Acta Part B, 1990, 45, 1353.

[79] M. Noda, Y. Deguchi, S. Iwasaki, N. Yoshikawa, Spectrochimica Acta Part B, 2002, 57, 701.

[80] Z.A. Arp, D.A. Cremers, R.D. Harris, D.M. Oschwald, G.R. Parker Jr., D.M. Wayne, Spectrochimica Acta Part B, 2004, 59, 987.

[81] B. Sallé, J.-L. Lacour, E. Vors, P. Fichet, S. Maurice, D.A. Cremers, R.C. Wiens, Spectrochimica Acta Part B, 2004, 59, 1413.

[82] D.A. Cremers, L.J. Radziemski, T.R. Loree, Applied Spectroscopy, 1984, 38, 721.

[83] R. Knopp, F.J. Scherbaum, J.I. Kim, Fresenius' Journal of Analytical Chemistry, 1996, 355, 16.

[84] H. Kurniawan, S. Nakajima, J.E. Batubara, M. Marpaung, M. Okamoto, K. Kagawa, Applied Spectroscopy, 1995, 49, 1067.

[85] K. Grant, G.L. Paul, J.A. O'Neill, Applied Spectroscopy, 1991, 45, 701.

[86] M. Sabsabi, P. Cielo, Applied Spectroscopy, 1995, 49, 499.

[87] F. Capitelli, F. Colao, M.R. Provenzano, R. Fantoni, G. Brunetti, N. Senesi, Geoderma, 2002, 106, 45.

[88] A.V. Pakhomov, W. Nichols, J. Borysow, Applied Spectroscopy, 1996, 50, 880.

[89] J.B. Ko, W. Sdorra, K. Niemax, Fresenius' Journal of Analytical Chemistry, 1989, 335, 648 .

[90] D.A. Rusak, M. Clara, E.E. Austin, K. Visser, R. Niessner, B.W. Smith, J.D. Winefordner, Applied Spectroscopy, 1997, 51, 1628.

[91] I.B. Gornushkin, P.E. Eagan, A.B. Novikov, B.W. Smith, J.D. Winefordner, Applied Spectroscopy, 2003, 57, 197.

[92] W. Gerlach, E. Schweitzer: Die chemische emissions Spektralanalyse I.: Grundlagen und Methoden, L. Voss,1929. 
[93] S. N. Thakur, J. P. Singh: Laser-induced breakdown spectroscopy, Elsevier, 2007.

[94] V. Sturm, L. Peter, R. Noll, Applied Spectroscopy, 2000, 54, 1275.

[95] L. Xu, V. Bulatov, V.V. Gridin, I. Schechter, Analytical Chemistry, 1997, 69, 2103.

[96] V. Lazic, R. Fantoni, F. Colao, A. Santagata, A. Morone, V. Spizzichino, Journal of Analytical Atomic Spectrometry, 2004, 19, 429.

[97] F.J. Fortes, M. Cortés, M.D. Simón, L.M. Cabalin, J.J. Laserna, Analytica Chimica Acta, 2005, 554, 136.

[98] J.A. Bolger, Applied Spectroscopy, 2000, 54, 181.

[99] D. Body, B.L. Chadwick, Spectrochimica Acta Part B, 2001, 56, 725.

[100] G. Chen, E.S. Yeung, Analytical Chemistry, 1988, 60, 2258.

[101] L. Grad, J. Možina, Applied Surface Science, 1993, 69, 370.

[102] F. Colao, R. Fantoni, V. Lazic, A. Paolini, F. Fabbri, G.G. Ori, L. Marinangeli, A. Baliva, Planetary and Space Science, 2004, 52, 117.

[103] F. Colao, R. Fantoni, V. Lazic, L. Caneve, A. Giardini, V. Spizzichino, Journal of Analytical Atomic Spectrometry, 2004, 19, 502.

[104] B. Sallé, J.-L. Lacour, P. Mauchien, P. Fichet, S. Maurice, G. Manhès, Spectrochimica Acta Part B, 2006, 61, 301.

[105] G. Galbács, I.B. Gornushkin, B.W. Smith, J.D. Winefordner, Spectrochimica Acta Part B, 2001, 56, 1159.

[106] G. Galbács, I.B. Gornushkin, J.D. Winefordner, Talanta, 2004, 63, 351.

[107] E.H. Piepmeier, H.V. Malmstadt, Analytical Chemistry, 1969, 41, 700.

[108] J. Übbing, J. Brust, W. Sdorra, F. Leis, K. Niemax, Applied Spectroscopy, 1991, $45,1419$.

[109] L. St-Onge, V. Detalle, M. Sabsabi, Spectrochimica Acta Part B, 2002, 57, 121.

[110] J. Scaffidi, W. Pearman, M. Lawrence, J.C. Carter, B.W. Colston Jr., S.M. Angel, Applied Optics, 2004, 43, 5243.

[111] J. Scaffidi, W. Pearman, J.C. Carter, S.M. Angel, Applied Spectroscopy, 2006. 60,65 .

[112] A. De Giacomo, M. Dell'Aglio, F. Colao, R. Fantoni, Spectrochimica Acta Part B, 2004, 59, 1431. 
[113] A. De Giacomo, M. Dell'Aglio, A. Casavola, G. Colonna, O. De Pascale, M. Capitelli, Analytical and Bioanalytical Chemistry, 2006, 385, 303.

[114] V.N. Rai, F.Y. Yueh, J.P. Singh, Applied Optics, 2003, 42, 2094.

[115] E. Koudoumas, M. Spyridaki, R. Stoian, A. Rosenfeld, P. Tzanetakis, I.V. Hertel, C. Fotakis, Thin Solid Films, 2004, 453-454, 372.

[116] A.C. Forsman, P.S. Banks, M.D. Perry, E.M. Campbell, A.L. Dodell, M.S. Armas, Journal of Applied Physics, 2005, 98, 1.

[117] X. Mao, X. Zeng, S.-B. Wen, R.E. Russo, Spectrochimica Acta Part B, 2005, 60, 960.

[118] R. Sattmann, V. Sturm, R. Noll, Journal of Physics D: Applied Physics, 1995, $28,2181$.

[119] C. Gautier, P. Fichet, D. Menut, J.-L. Lacour, D. L'Hermite, J. Dubessy, Spectrochimica Acta Part B, 2005, 60, 265.

[120] S.M. Angel, D.N. Stratis, K.I. Eland, T. Lai, M.A. Berg, D.M. Gold, Fresenius' Journal of Analytical Chemistry, 2001, 369, 320.

[121] R. Noll, R. Sattmann, V. Sturm, S. Winkelmann, Journal of Analytical Atomic Spectrometry, 2004, 19, 419.

[122] J. Scaffidi, S. M. Angel, D.A. Cremers, Analytical Chemistry, 2006, 78, 24.

[123] V.I. Babushok, F.C. Delucia Jr., J.L. Gottfried, C.A. Munson, A.W. Miziolek, Spectrochimica Acta Part B, 2006, 61, 999.

[124] A. Löbe, J. Vrenegor, R. Fleige, V. Sturm, R. Noll, Analytical and Bioanalytical Chemistry, 2006, 385, 326.

[125] C. Hartmann, A. Gillner, Ü. Aydin, R. Noll, T. Fehr, C. Gehlen, R. Poprawe, Journal of Physics: Conference Series, 2007, 59, 440.

[126] C. Lopez-Moreno, K. Amponsah-Manager, B.W. Smith, I.B. Gornushkin, N. Omenetto, S. Palanco, J.J. Laserna and J.D. Winefordner, Journal of Analytical Atomic Spectrometry, 2005, 20, 552.

[127] G. Christoforetti, S. Legnaioli, V. Palleschi, A. Salvetti, E. Tognoni, P.A. Benedetti, F. Brioschi, F. Ferrario, Journal of Analytical Atomic Spectrometry, 2006, 21, 697 .

[128] A. Freedman, F.J. Iannarilli Jr., J.C. Wormhoudt, Spectrochimica Acta Part B, 2005, 60, 1076 . 
[129] G. Galbács, N. Jedlinszki, G. Cseh, Z. Galbács, L. Túri, Spectrochimica Acta Part $B, \mathbf{2 0 0 8}, 63,591$.

[130] N. Jedlinszki, G. Galbács, Microchemical Journal, 2011, 97, 255.

[131] E.H. Piepmeier, D.E. Osten, Applied Spectroscopy, 1971, 25, 642.

[132] V. Sturm, J. Vrenegor, R. Noll, M. Hemmerlin, Journal of Analytical Atomic Spectrometry, 2004, 19, 451.

[133] H. Balzer, M. Höhne, R. Noll, V. Sturm, Analytical and Bioanalytical Chemistry, 2006, 385, 225.

[134] R. Noll, V. Sturm, Ü. Aydin, D. Eilers, C. Gehlen, M. Höhne, A. Lamott, ]. Makowe, J. Vrenegor, Spectrochimica Acta Part B, 2008, 63, 1159.

[135] I.V. Cravetchi, M.T. Taschuk, Y.Y. Tsui, R. Fedosejevs, Analytical and Bioanalytical Chemistry, 2006, 385, 287.

[136] I.V. Cravetchi, M.T. Taschuk, Y.Y. Tsui, R. Fedosejevs, Spectrochimica Acta Part $B, \mathbf{2 0 0 4}, 59,1439$.

[137] J. Gruber, J. Heitz, H. Strasser, D. Bäuerle and N. Ramaseder, Spectrochimica Acta Part B, 2001, 56, 685.

[138] G. Hubmer, R. Kitzberger, K. Mörwald, Analytical and Bioanalytical Chemistry, 2006, 385, 219.

[139] R. Noll, I. Mönch, O. Klein, A. Lamott, Spectrochimica Acta Part B, 2005, 60, 1070.

[140] A. De Giacomo, M. Dell'Aglio, F. Colao, R. Fantoni, V. Lazic, Applied Surface Science, 2005, 247, 157.

[141] J. Vrenegor, R. Noll, V. Sturm, Spectrochimica Acta Part B, 2005, 60, 1083.

[142] H. Balzer, S. Hölters, V. Sturm, R. Noll, Analytical and Bioanalytical Chemistry, 2006, 385, 234.

[143] S. Koch, W. Garen, M. Müller, W. Neu, Applied Physics A: Materials Science \& Processing, 2004, 79, 1071.

[144] P. Fichet, A. Toussaint, J.-F. Wagner, Applied Physics A: Materials Science \& Processing, 1999, 69, S591.

[145] T. Bundschuh, J. Yun, R. Knopp, Fresenius' Journal of Analytical Chemistry, 2001, 371, 1063. 
[146] F. Hilbk-Kortenbruck, R. Noll, P. Wintjens, H. Falk, C. Becker, Spectrochimica Acta Part B, 2001, 56, 933.

[147] M.F. Bustamante, C.A. Rinaldi, J.C. Ferrero, Spectrochimica Acta Part B, 2002, $57,303$.

[148] M.H. Ebinger, M.L. Norfleet, D.D. Breshears, D.A. Cremers, M.J. Ferris, P.J. Unkefer, M.S. Lamb, K.L. Goddard, C.W. Meyer, Soil Science Society of America Journal, 2003, 67, 1616.

[149] L. Niu, H. Cho, K. Song, H. Cha, Y. Kim, and Y. Lee, Applied Spectroscopy, 2002, 56, 1511 .

[150] R. Barbini, F. Colao, V. Lazic, R. Fantoni, A. Palucci, M. Angelone, Spectrochimica Acta Part B, 2002, 57, 1203.

[151] V. Lazic, R. Barbini, F. Colao, R. Fantoni, A. Palucci, Spectrochimica Acta Part $B, \mathbf{2 0 0 1}, 56,807$.

[152] M.A. Gondal, T. Hussain, Z.H. Yamani, M.A. Baig, Talanta, 2006, 69, 1072.

[153] D. Anglos, Applied Spectroscopy, 2001, 55, 186A.

[154] K. Melessanaki, M.P. Mateo, S.C. Ferrence, P.P. Betancourt, D. Anglos, Applied Surface Science, 2002, 197-198, 156.

[155] M. Bicchieri, M. Nardone, P.A. Russo, A. Sodo, M. Corsi, G. Cristoforetti, V. Palleschi, A. Salvetti, E. Tognoni, Spectrochimica Acta Part B, 2001, 56, 915.

[156] F. Colao, R. Fantoni, V. Lazic, V. Spizzichino, Spectrochimica Acta Part B, 2002, 57, 1219.

[157] B. Sallé, D.A. Cremers, S. Maurice, R.C. Wiens, Spectrochimica Acta Part B, 2005, 60, 479.

[158] L. St-Onge, E. Kwong, M. Sabsabi, E.B. Vadas, Spectrochimica Acta Part B, 2002, 57, 1131.

[159] M.D. Mowery, R. Sing, J. Kirsch, A. Razaghi, S. Béchard, R.A. Reed, Journal of Pharmaceutical and Biomedical Analysis, 2002, 28, 935.

[160] Q. Sun, M. Tran, B.W. Smith, J.D. Winefordner, Talanta, 2000, 52, 293.

[161] A. Kumar, F.-Y. Yueh, J.P. Singh, S. Burgess, Applied Optics, 2004, 43, 5399.

[162] D. Mukherjee, A. Rai, M.R. Zachariah, Journal of Aerosol Science, 2006, 37, 677.

[163] R.S. Harmon, F.C. DeLucia Jr., A. LaPointe, R.J. Winkel Jr., A.W. Miziolek, Analytical and Bioanalytical Chemistry, 2006, 385, 1140. 
[164] M. Baudelet, L. Guyon, J. Yu, J.-P. Wolf, Applied Physics Letters, 2006, 88, 063901-1.

[165] C.R. Dockery, S.R. Goode, Applied Optics, 2003, 42, 6153.

[166] E.M. Rodriguez-Celis, I.B. Gornushkin, U.M. Heitmann, J.R. Almirall, B.W. Smith, J.D. Winefordner, N. Omenetto, Analytical and Bioanalytical Chemistry, 2008, 391, 1961.

[167] Pallai S., Nemesfémipari zsebkönyv, Műszaki Könyvkiadó, 1987.

[168] Colloquium Spectroscopicum Internationale XXXVI, 2009.08.30-09.03., Budapest, No. OL62

[169] D.N. Stratis, K.L. Eland, S.M. Angel, Applied Spectroscopy, 2000, 54, 1719.

[170] D.N. Stratis, K.L. Eland, S.M. Angel, Applied Spectroscopy, 2000, 54, 1270.

[171] S.H. Tavassoli, A. Gragossian, Optics \& Laser Technology, 2009, 41, 481.

[172] P.A. Benedetti, G. Cristoforetti, S. Legnaioli, V. Palleschi, L. Pardini, A. Salvetti, E. Tognoni, Spectrochimica Acta Part B, 2005, 60, 1392.

[173] A. Bogaerts, Z. Chen, D. Autrique, Spectrochimica Acta Part B, 2008, 63, 746.

[174] C.D. Gehlen, P. Roth, Ü. Aydin, E. Wiens, R. Noll, Spectrochimica Acta Part B, 2008, 63, 1072 .

[175] C. Aragon, J.A. Aguilera, Applied Spectroscopy, 1997, 51, 1632.

[176] C. Gautier, P. Fichet, D. Menut, J. Dubessy, Spectrochimica Acta Part B, 2006, $61,210$.

[177] H. Matsuta, K. Wagatsuma, Applied Spectroscopy, 2002, 56, 1165.

[178] T. M. Naeem, H. Matsuta, K. Wagatsuma, Spectrochimica Acta Part B, 2003, $58,891$.

[179] S. Nakamura, K. Wagatsuma, Spectrochimica Acta Part B, 2007, 62, 1303.

[180] G. Cristoforetti, S. Legnaioli, V. Palleschi, A. Salvetti, E. Tognoni, Applied Physics B, 2005, 80, 559.

[181] C. Gautier, P. Fichet, D. Menut, J.-L. Lacour, D. L'Hermite, J. Dubessy, Spectrochimica Acta Part B, 2005, 60, 1392.

[182] E. Tognoni, V. Palleschi, M. Corsi, G. Cristoforetti, Spectrochimica Acta Part B, 2002, 57, 1115 .

[183] R.A. Multari, L.E. Foster, D.A. Cremers, M.J. Ferris, Applied Spectroscopy, $1996,50,1483$. 
[184] M. Corsi, G. Cristoforetti, V. Palleschi, A. Salvetti, E. Tognoni, The European Physical Journal D, 2001, 13, 373.

[185] D. Bulajic, M. Corsi, G. Cristoforetti, S. Legnaioli, V. Palleschi, A. Salvetti, E. Tognoni, Spectrochimica Acta Part B, 2002, 57, 339.

[186] M.C. Ortiz, L. Sarabia, A. Jurado-López, M.D. Luque de Castro, Analytica Chimica Acta, 2004, 515, 151.

[187] C. Gautier, P. Fichet, D. Menut, J.-L. Lacour, D. L'Hermite, J. Dubessy, Spectrochimica Acta Part B, 2004, 59, 975.

[188] A. Bogaerts, Z. Chen, Spectrochimica Acta Part B, 2005, 60, 1280.

[189] Directive 2002/95/EC of the European Parliament and of the Council, Offical Journal of the European Union, L 37/19, 13.2.2003

[190] Y. Suzuki, M. Kasamatsu, S. Suzuki, Y. Marumo, Analytical Sciences, 2001, 17, 845.

[191] Y. Yamamoto, J. Noro, Analytical Sciences, 1998, 14, 443.

[192] T.J. Schmitt, J.P. Walters, D.A. Wynn, Applied Spectroscopy, 1989, 43, 687.

[193] D.A. Wynn, Talanta, 1993, 40, 1207.

[194] H.F. Bell, Analytical Chemistry, 1973, 45, 2296.

[195] N.B. Zorov, A.A. Gorbatenko, T.A. Labutin, A.M. Popov, Spectrochimica Acta Part $B$, 2010, 65, 642 . 


\section{A szerző közleményeinek listája}

\section{Az értekezés alapjául szolgáló közlemények:}

1. G. Galbács, N. Jedlinszki, G. Cseh, Z. Galbács, L. Túri: Accurate quantitative analysis of gold alloys using multi-pulse laser induced breakdown spectroscopy and a correlation-based calibration method, Spectrochimica Acta Part B, 63 (2008) 591-597.

$$
\mathrm{IF}_{\mathbf{2 0 0 8}}=\mathbf{2 , 8 5 3}
$$

2. G. Galbács, N. Jedlinszki, K. Herreira, B. Lauly, N. Omenetto, J.D. Winefordner: A study of ablation, spatial and temporal characteristics of laserinduced plasmas generated by multiple collinear pulses, Applied Spectroscopy, 64 (2010) 91-102.

$$
\mathrm{IF}_{2009}=1,564
$$

3. N. Jedlinszki, G. Galbács: An evaluation of the analytical performance of collinear multi-pulse laser induced breakdown spectroscopy, Microchemical Journal, 97 (2011) 255-263.

$$
\text { IF }_{2009}=2,579
$$

\section{$\Sigma I F=6,996$}

\section{Egyéb közlemény:}

1. G. Galbács, I. Kevei-Bárány, E. Szőke, N. Jedlinszki, I.B. Gornushkin, M.Z. Galbács: A study of stalagmite samples from Baradla Cave (Hungary) by laser induced plasma spectrometry with automatic signal correction, Microchemical Journal, közlésre benyújtva 


\section{Konferencia részvételek (előadások, poszterek):}

1. Galbács G., Cseh G., Galbács Z., Jedlinszki N.: Műanyag minták RoHS megfelelőségi vizsgálata többszörös lézerimpulzusokkal indukált plazma spektroszkópiával, 49. Magyar Spektrokémiai Vándorgyülés, 2006. július 10-12., Miskolc Szóbeli előadás

2. Galbács G., Jedlinszki N., Cseh G.: Elemanalitikai mérések lézer- és röntgensugárzással működő korszerű spektrométerekkel, $13^{\text {rd }}$ Symposium on Analytical and Environmental Problems, September 25, 2006, Szeged

Poszter

3. Jedlinszki N.: Műanyag minták elemanalitikai célú vizsgálata spektroszkópiai módszerekkel, XXVIII. Országos Tudományos Diákköri Konferencia, 2007. április 2-4., Szeged

\section{Előadás}

4. Galbács G., Cseh G., Jedlinszki N., Galbács Z.: A többszörös impulzusokkal kivitelezett lézer indukált plazma spektroszkópia analitikai alkalmazásai, 50. Centenáriumi Vegyészkonferencia, 2007. május 29-június 1, Sopron

\section{Szóbeli előadás}

5. Jedlinszki N., Cseh G., Galbács G.: Aranyötvözetek pontos mennyiségi analízise lézer indukált plazma spektrométerrel, $14^{\text {th }}$ Symposium on Analytical and Environmental Problems, September 24, 2007, Szeged

\section{Poszter}

6. G. Galbács, N. Jedlinszki, G. Cseh, Z. Galbács, L. Túri: Accurate quantitative analysis of gold alloys using multi-pulse laser induced breakdown spectroscopy and a correlation-based calibration method, 2008 Pittsburgh Conference, March 2-8, 2008, New Orleans, USA

\section{Poszter}

7. N. Jedlinszki, G. Cseh, G. Galbács: Application of laser induced breakdown spectroscopy to the qualitative analysis of samples related to the human health, 10th DKMT Conf. on Cross-border Bioecology and Public Health, May 16-17, 2008, Arad, Romania

\section{Poszter}


8. N. Jedlinszki, G. Galbács, B. Lauly: Spatially and temporally resolved studies on LIB plasmas induced by multiple laser pulses, 5th International Conference on LIBS (LIBS 2008), 2008, September 22-26, Berlin, Germany

Poszter

9. N. Jedlinszki, G. Cseh, G. Galbács: Evaluation of the analytical performance of multi-pulse laser-induced breakdown spectroscopy (MP-LIBS), Colloquium Spectroscopicum Internationale XXXVI, August 30-September 3, 2009, Budapest

\section{Előadás}

10. A. Buzás, Zs. Geretovszky, N. Jedlinszki, G. Galbács: On the role of the elevated temperature of the target in the enhanced emission signal in multipulse laser-induced breakdown plasma (MP-LIBS) spectroscopy, Colloquium Spectroscopicum Internationale XXXVI, August 30-September 3, 2009, Budapest

\section{Előadás}

11. Jedlinszki N., Galbács G.: A többimpulzusos lézer indukált plazma spektroszkópia (MP-LIBS) analitikai teljesítőképességének vizsgálata, XXXII. Kémiai Előadói Napok Tudományos Szimpózium, 2009. október 26-28., Szeged

\section{Előadás}

12. Galbács G., Jedlinszki N., Geretovszky Zs.: Az analitikai jellemzők javítása a lézer indukált plazmaspektroszkópiában, MKE Analitikai Napok, 2010. január 28-29., Budapest

\section{Előadás}

13. Jedlinszki N., Kukovecz Á., Galbács G.: Többimpulzusos lézer ablációs kráterek morfológiai és kémiai jellemzőinek tanulmányozása, Vegyészkonferencia és 53. Magyar Spektrokémiai Vándorgyülés, 2010. június 30-július 2., Hajdúszoboszló

\section{Előadás}

14. G. Galbács, N. Jedlinszki: A comparative evaluation of the efficiency of signal normalization methods in SP-LIBS and MP-LIBS, XIV. Hungarian-Italien Symposium on Spectrochemistry, 2011. október 5-7., Sümeg, Hungary

Bejelentett előadás 
15. G. Galbács, N. Jedlinszki, A. Metzinger, K. Fintor: Use of complementary spectral information from micro-Raman and LIBS spectroscopy for discrimination between papers and printing ink types, XIV. Hungarian-Italien Symposium on Spectrochemistry, 2011. október 5-7., Sümeg, Hungary

Bejelentett előadás 


\section{Köszönetnyilvánítás}

Köszönettel tartozom Kiss Tamás tanszékvezetőnek, amiért biztosította számomra a lehetőséget, hogy a Szervetlen és Analitikai Kémiai Tanszéken doktori munkámat elkészítsem.

Köszönetet mondok témavezetőmnek, Galbács Gábornak, akinek szakmai támogatása és határtalan türelme mellett emberi támogatására is bármikor számíthattam.

Hálás vagyok azoknak a munkatársaimnak, akik tanácsaikkal segítették munkámat és baráti légkört teremtettek. Külön köszönöm Sebőkné Kiss Mariannának az évek során köztünk kialakult barátságot.

Köszönetet mondok Galbács Zoltánnak, akihez bármilyen problémával szintén bizalommal fordulhattam.

Köszönettel tartozom Pallósi Józsefnek (ISD Dunaferr Zrt.) az acél mintasorozatért és Túri Lászlónak (Festék Bázis Kft.) az aranyötvözetekért.

Hálával tartozom szüleimnek, családomnak, akik mindvégig támogattak abban, hogy doktori tanulmányaimat sikeresen elvégezzem.

Végül, de nem utolsó sorban köszönetet szeretnék mondani minden barátomnak, akik az évek során mindvégig mellettem álltak és tanácsaikkal segítettek. 